\title{
A MODERNIZAÇÃO DA AGRICULTURA E A EDUCAÇÃO AGRICOLA SUPERIOR: O CASO DA UNIVERSIDADE DE ZULIA - VENEZUELA
}

JESUS ALEJANDRO PAZOS ROSAL

Orientador: Dr. Oriowaldo Oueda

Dissertação apresentada à Escola Superior de Agricultura "Luiz de Queiroz", da Universidade de São Paulo, para obłenção do título de Mestre em Sociologia Rural. 


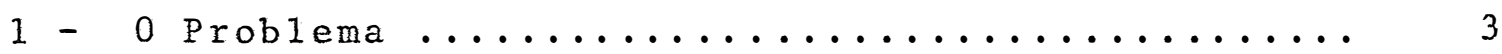

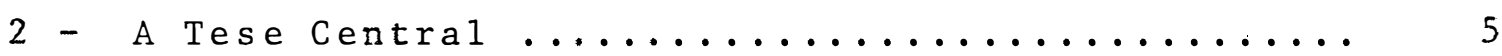

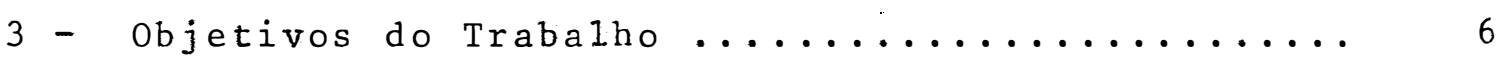

4 - organização do Trabalho ................... 7

CAPITULO I - REFERENCIAL TEDRICO ............. 9

1 - A Sociedade Dual: Trauma da América Latina .... 9

2 - A Modernização e a Redenção Camponesa ......... 22

3 - Extensão Rural ou Extensão do Capitalismo ? .... 28

4 - A Universidade como Produtora de Reprodutores . . 38

CAPItUlo II - A Agricultura VEnEZUELANA .......... 49

1 - Petróleo, Felicidade ou Desgraça ?........... 49

2 - Uma Politica Agrícola Comprometida ........... 56

3 - 0 Campo sob o Signo da Democracia ............ 67

4 - Epílogo: Aprendendo do "conuco" ............ 83

CAPITULO III - A FORMAÇÃO DO AGRÔNOMO NO CONTEXTO ZULIANO $\ldots \ldots \ldots \ldots \ldots \ldots \ldots \ldots \ldots$

1 - Consideraçöes Gerais ..................... 89

2 - 0 Agrônomo, um Agente de Mudança Comprometido .. 94 
Pàgina

3. Disciplinas Sociais V.s. Disciplinas Técnicas, uma Luta Desigual ................ 100

CAPITULO IV - CONCLUSÕES E SUGESTÕES ......... 116

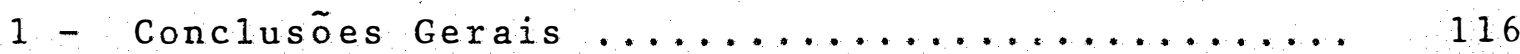



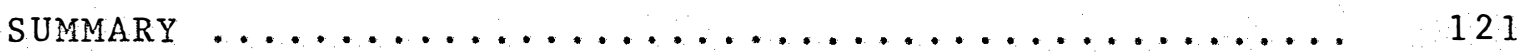

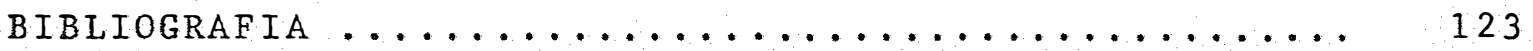

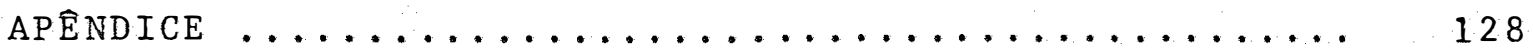




\section{LISTA DAS TABELAS}

Pāgina

TABELA 1 - Distribuição da posse da terra. Vene-



TABElA 2 - Fertilizantes. Produção e Importação em toneladas métricas. Venezuela,

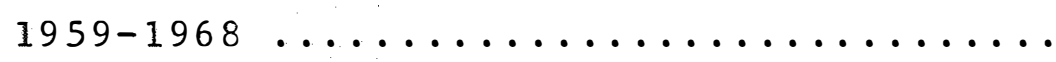

TABELA 3 - Inseticidas. Produção e Importação em toneladas metricas. Venezuela, 1959-

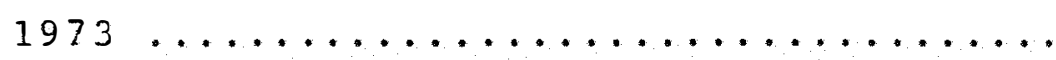

TABELA 4 - Produtos biológicos elaborados pelo Mi nistério da Agricultura, Venezuela,

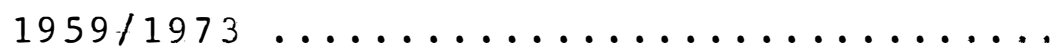

TABELA 5 - Produção de alimentos concentrados para bovinos, suinos e aves em toneladas métricas. Venezuela, $1950+1973 \ldots . . .$.

TABELA 6 - Nümero de mäquinas e instrumentos agrí colas importados. Venezuela, $1955 / 197.3 . .80$

TABELA 7 - Ārea colhida e estimativa da ārea meca nizada das principais culturas em mi1hões de hectares. Venezuela, $1965 /$



TABELA 8 - Planos de estudos da Faculdade de Agro nomia da Universidade de Zulia, Mara caibo, Venezuela, $1978 \ldots \ldots \ldots \ldots \ldots$ 
Página

TABELA 9 - Disciplinas bio-físicas e sócio-econô micas oferecidas pela Faculdade de Agronomia da Universidade de Zulia, Ma racaibo, Venezuela, $1978 \ldots \ldots \ldots \ldots \ldots 101$

TABELA 10 - Disciplinas criadas pela Faculdade de Agronomia da Universidade de Zulia, Maracaibo, Venezuela, entre 1970 e

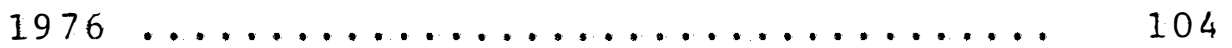

TABELA 11 - Nümero de Professores e países onde realizaram cursos de especialização. Faculdade de Agronomia da Universidade Zulia, Maracaibo, Venezuela, 1978 ... 106 
Pàgina

TABELA I - Setor Agrícola. Produção em toneladas métricas. Venezuela, $1972 / 1976 \ldots \ldots$.

TABELA II - Setor Agrícola. Area colhida em hecta res. Venezuela, $1972 / 19.76 \ldots \ldots \ldots \ldots$

TABELA III - Setor Agrícola. Produção bruta. Vene zuela, $1972 / 1976 \ldots \ldots \ldots \ldots \ldots \ldots \ldots \ldots \ldots \ldots \ldots \ldots \ldots \ldots$

TABELA IV - Disciplinas bio-físicas e sócio-econômicas oferecidas pela Faculdade de Agronomia da Universidade de Zulia, Ma racaibo, Venezue1a, $1978 \ldots \ldots \ldots \ldots$

TABELA V - Objetivos propostos para as discipli nas oferecidas pela Faculdade de Agronomia da Universidade de Zulia, Maracaibo, venezuela, 1970/1976 ......... 
Neste trabalho, o autor discute a importäncia que tem a formação acadêmica recebida pelo aluno de agronomia, na imple mentação da polîtica de modernização da agricultura. Para o caso específico da venezuela, tomou-se como ponto de referéncia a formação ministrada na Faculdade de Agronomia da Universidade de Zulia, Maracaibo - Venezuela.

Considera o autor, que tal formação é uma maneira de preparar "recursos humanos" especializados em técnicas agríco las, não com o fim de ajudar o camponēs venezuelano a melhorar suas atuais condições de vida; pelo contrārio, tal formação é dirigida à reprodução e consolidação das relações de produção capitalistas vigentes no meio rural do país. Esta situação é - resultado da imposição ideológica de orientação capitalista por parte das classes dominantes, de toda uma estratégia de mu dança que se fundamentou nas teorias da sociedade dual, modernização e mudança social. 
Para comprovaçao desta tese central, foram consulta dos e analisados vārios documentos, os quais continham os pres supostos teóricos em que se fundamentou toda a política de mo dernização da agricultura a nível latinoamericano. Partindo disto, são analisados alguns aspectos da atual politica agrícola venezuelana, como também as características mais impor tantes do meio rural como consequéncia direta da modernização e, por ūltimo, a anālise do Plano de Estudos vigente na forma ção de Engenheiros Agrōnomos na referida Faculdade.

E evidente a formação tecnicista do aluno de Agrono mia dirigida à obtenção de um profissional altamente especializado nas mais sofisticadas técnicas que requer a atividade agrícola da atualidade e que somente podem ser adotadas e uti $l$ izadas por um pequeno setor, dominante e poderoso, dando lugar para que se acentuem as diferenças econōmicas e sociais en tre os diferentes setores que integram a estrutura social do meio rural venezuelano.

A formação recebida pelo aluno na Faculdade de Agro nomia da Universidade de Zulia, em sintese, está dirigida para formar um agente de mudança tecnológica e não um agente pa ra a mudança estrutural e total, que o país, em sua condição de subdesenvolvido e de economia capitalista dependente, exige para sua total independēncia. 


\section{1 - O PROBLEMA}

Terminada a Segunda Guerra Mundial, os anos seguintes foram cruciais quanto às relações entre os Estados Unidos e a América Latina, em face dos desajustes económicos que o referido conflito ocasionou na estrutura interna desta ūltima. E sabido de todos que com o resultado vitorioso dos Estados $\underline{U}$ nidos, em 1945, consolidou-se, por assim dizer, sua hegemonia como primeira poténcia capitalista a nivel mundial.

Pouco depois do término desse conflito armado, que acabou provocando uma nova divisão do mundo entre os países capitalistas com desejos de expansão, os Estados Unidos se de dicam, imediatamente, à reorganização de sua economia, sendo de vital importāncia, para isso, a recuperação de seus mercados, de modo especial aqueles localizados na área de sua influéncia económica, como eram os mercados latinoamericanos. 
Assim, por intermédio de certos organismos internacionais, e escudados em estudos sobre aspectos económicos da América Latina, teōricos do desenvolvimento capitalista, fize ram crer e aceitar, como vālida, nas classes dirigentes des ses paîses, a tese de que as relações de produção não capitalistas, muito embora existentes no meio rural, eram as causadoras da não expansão do mercado interno, consumidor dos prod utos que, de maneira crescente, o setor industrial produzia.

Esta situação se devia, do ponto de vista capitalís ta, ao fato de existir nesses países um setor rural, tradicio nal e atrasado - sem nenhuma possibilidade de desenvolver-se, a menos que se ajudasse a fazê-lo; em contraposição com um setor moderno e em vias de alcançar um nível de desenvolvimen to cada vez maior.

Por isso, era indispensāvel por parte dos governos da região, a implementação de uma polîtica dirigida à trans formação desse meio rural atrasado, o qual permitiria uma abertura maior do mercado, mas isto só seria possīvel alcançar, mediante a modernização da agricultura, em outras palavras, me diante a modernização das forças produtivas e, por conseguinte, das relações de produção.

Desde esse momento, a expansão do capitalismo norte americano em sua fase de pōs-guerra envolveu toda a ārea da $\underline{A}$ mérica Latina em um amplo movimento de mudança, dirigido à con solidação das relações de produção capitalista ou, ao menos, para provocar alterações em outras relações jā existentes a fim de lograr impor as primeiras. 
Para conseguir esta ação de mudança, estribava-se em uma fundamentação teōrica (a sociedade dual), existindo uma es tratégia politica que a implementava (a modernização) e conta va-se, ainda, com o instrumento técnico e metodológico para concretizā-la (a Extensão Rural) .

Desta forma, no meio rural latinoamericano, a agricultura como provedora de alimentos e de matéria-prima de or $\underline{i}$ gem agrícola, porém, escassos naqueles momentos, converteu-se no centro para onde convergiam as forças que dinamizavam o pro cesso de expansão capitalista por meio da modernização.

\section{2 - A tese Central}

No caso específico da Venezuela, a politica de modernização tem sido considerada pelas classes dirigentes do paîs, como condição "sine qua non" para solucionar os problemas de um setor agrícola que, segundo alguns idealistas do de senvolvimento a serviço do Estado, não tem conseguido acompanhar ao crescimento económico alcançado em outros setores, co mo é o caso do setor industrial, pelo simples motivo de que o camponês venezuelano não se acha capacitado para receber e $\underline{a}$ dotar a nova tecnologia agrícola.

Disto surge que, com relação ao papel do agrōnomo diante desta problemātica, tem-se que considerar o seguinte:

- que longe de receber uma formação académica integral;

- amparada no conhecimento objetivo das verdadeiras causas do entravamento rural venezuelano; 
- constituindo-se desta forma num elemento importante na con figuração de um meio rural mais justo;

- que ofereça às massas camponesas as mīnimas condições mate riais;

- permitindo-lhes realizar-se integralmente, passando a ser donas do produto de seu esforço;

e eis aqui a hipótese central: nosso profissional de agronomia vem recebendo uma formação acadêmica dirigida à reprodu ção das relações de produção capitalistas imperantes no meio rural venezuelano.

3 - Objetivos do TRabalho

A partir da problemática anterior, o trabalho tem co mo objetivos:

a - Verificar até que ponto a modernização, fundamentada na teoria da sociedade dual, vem influenciando nas decisões tomadas pelo Estado com relação às politicas agrícolas;

b - Verificar em que medida, a atual polittica do Estado está orientada para a implementação da modernização no setor agrícola;

c - Verificar até que ponto o "curriculum" a ser cumprido na formação do engenheiro agrónomo, está sendo orientado pa ra fazer dele um agente da política de modernização. 


\section{4 - Organiząão do TrabalHo}

Para alcançar os objetivos propostos, procurar-se-ā discutir o caso especifico do ensino especializado na forma ção do engenheiro agrónomo por parte da Faculdade de Agrono mia da Universidade de Zulia, Maracaibo-Venezuela ; necessitando, por isso, a consulta e anālise de uma série de documen tos que nos permitiram uma visão total do problema.

Acha-se conveniente esclarecer que o presente traba Tho não pretende, em instante algum, exaurir a revisão de tudo que se tem escrito em matéria de sociedade dual, moderniza ção ou mudança social na América Latina, para depois, no final, emitir conclusões a respeito do que se deve ou não enten der e fazer em relação a estes temas polémicos do pensamento sociológico.

Para tal fim, no Capītulo I , tratar-se-á de colocar os fundamentos teóricos básicos que nos permitirão discutir de que forma a tese da sociedade dual e os conceitos de modernização e mudança social, foram elaborados com a finalidade de propugnar pela consolidação das relações de produção capitalistas no meio rural latinoamericano.

No Capitulo II , procurar-se-á caracterizar o setor agrícola venezuelano nos momentos atuais, como também assinalar alguns aspectos da politica que; sobre o setor agrícola,a pesquisa agrícola, a educação agrícola, a ciēncia e a tecnolo gia, estão contidas no V Plano da Nação, como instrumento englobador das diretrizes essenciais do desenvolvimento econōmi 
co e social da Repüblica durante o período de 1976 a 1980,com provando, de certa forma, o que se formulou teoricamente no Capitulo I.

Por ūitimo, no Capítulo III, mediante a anālise dos programas vigentes na Faculdade de Agronomia da Universidade de Zulia, procurar-se-à comprovar como, através da formação a cadêmica recebida, o engenheiro agrōnomo é orientado para atender os reclamos exigidos pela politica de modernização, constituindo-se num elemento fundamental na estratégia analisada nos capitulos anteriores. 


\section{CAPİTULO I - REFERENCIAL TEŌRICO}

Neste Capĩtulo, procurar-se-à uma justificação teórica para a anālise da tese central do trabalho.

1 - A Sociedade Dual: Um Trauma da America latina

Considerando-se a politica de modernização como um elemento a mais na reprodução das relações de produção capita lista no meio rural latinoamericano ou do capitalismo em geral, é conveniente recordar que este constitui toda uma forma ção histōrica global.

Como tal, esta formação tem como fundamento uma estrutura característica que se desenvolve em torno da propriedade privada dos meios de produção e da disponibilidade da for ça de trabalho por parte de um numeroso contingente humano, tú do isto associado a uma utilização crescente dos recursos que a ciència e a técnica colocam à sua inteira disposição. 
Por capitalismo, não somente pode ser entendido como o conjunto dos objetos de trabalho, de meios de produção, ou de subsistēncia, como também torna-se necessārio que estes elementos estejam ligados a determinadas relações de produção. Outro aspecto importante a considerar, é que, sendo um trabalho acumulado, o capital pressupõe a relação com a for ça de trabalho viva que multiplica seu valor dando lugar à mais-valia, e, esta, por sua vez, atua como estímulo na produ ção de maior mais-valia nos ciclos de reprodução dentro de um contexto social determinado, no qual o crescimento da produ ção do trabalho alcança altos níveis devido à rica composição técnica das forças produtivas, e disto surge a importāncia da politica de modernização.

Em um contexto social com tais caracteristicas, como é o caso da América Latina, é bem clara a contradição bās ca do capitalismo: o carāter social da produção e o carāter privado da apropriação dessa produção. Isto quer dizer que a apropriação individual e privada, tanto do excedente econōmico como dos meios de produção, em um momento determinado entra em contradição com o trabalho, ou seja, a riqueza social produzida pelo trabalho da maioria da população, é apropriada em proporções cada vez maiores por uma minoria de indivíduos.

Esta, em poucas palavras, tem sido a origem da composição das classes no contexto social latinoamericano: por um lado os que tém a propriedade dos meios de produção e por outro, os que se véem na obrigação de vender seu trabalho, se 
ja manual, técnico ou intelectual.

No caso da América Latina, onde o sistema capitalí ta é, além de tudo, dependente e subdesenvolvido, tàl contradição gerou a crescente marginalização que caracterizava o se tor agrîcola, onde permaneciam formas de produção do tipo colonial e que foram mantidas pelo modo de produção dominante, a fim de manter uma estrutura de exploração econōmica e de do minação ideológica polîtica por parte dessa minoria dominante aliada ao capitalismo estrangeiro.

Contudo, ocorre que estas formas consideradas atrasadas e de origem colonial, (parceria, arrendamento, etc.) constituem-se em um determinado instante, num elemento que obs taculiza e inibe o processo de desenvolvimento das forças pro dutivas capitalistas, sobretudo no que se refere às relações de produção; disto surge a necessidade de que os trabalhado res diretos sejam despojados de todo tipo de propriedade dos meios de produção, porque para o desenvolvimento capitalista, essas relações de produção poderiam constituir-se em obstāculos para seu desenvolvimento, sendo conveniente, então, uma $\underline{a}$ ção de mudança voltada à sua substituição por outras.

Para substituir estas relações de produção atrasa das teve-se como pressuposto, atribuir o estado de atraso eco nómico-de uma região, às caracterîsticas psicológicas de seus membros, porquanto, à mudança se encontraria através da motivação, isto é, despertando o interesse dias pessoas para ele vâr suas aspirą̧ões. 
Estas forças psicológicas eram consideradas como suficientes e necessārias para se conseguir uma mudança de atitude no modo de pensar tradicional, pois, como diz DUNCAN (1964:4) "não estamos interessados apenas em ensinar e assegu rar a adoção de determinada prática recomendada, interessa-nos a mudança de mentalidade do agricultor. (...) ensinar o homem do campo a pensar", ou como enfatiza MAUNDER (1973:8), "pa ra lograr uma aceleração marcante e firme da produtividade a grícola, é necessārio romper com as atitudes tradicionais visando à mudança".

$\mathrm{Na}$ verdade, assim foram concebidos os programas de extensão agrīcola para a América Latina. Ao mesmo tempo que visavam a necessidade de uma mudança tecnológica,centrada na modernização do setor agrícola que elevaram os indices de pro dução e de produtividade, o conceito de mudança era visto como a transformação das relações técnicas (mudança tecnológi ca) mas, que, na realidade, significava uma mudança de atitude por parte de certos setores da população rural; por isso, - modelo de mudança estava ligado a uma concepção psicológica. Para PINTO (1972:17-18) "esta concepção de que a mu dança dá-se quando se muda a mentalidade da gente, obedecia a uma redução que faz explicar a realidade sccial pelo elemento psicológico, onde as idêias ou concepções das pessoas são suas atitudes ou motivações as que definem a realidade social e mudando-se aquejas, este tanbén será mudada".

ou seja, a realidade social não era entendida, se- 
gundo PINTO (1972:30) como "o conjunto de processos e relações entre processos que conformam uma totalidade, cuja existência não depende da consciēncia ou percepção humanas e cuja dinâmi ca é dada pelas contradições que constituem a mesma essência destes processos".

A estrutura social tambëm, é uma totalidade de partes em relação dialética entre si, das quais alguns níveis exercem sobre outros uma relação de determinação. Esses niveis são: o nível de produção, que constitui a base da estrutura; o nivel jurîdico-politico e o nível ideológico, que formam a superestrutura.

Considerando-se que a atividade fundamental que o ho mem exerce, é aquela orientada para a produção de bens destinados à satisfação de suas necessidades primärias ou vitais, logicamente é o nível produtivo que determina todo o resto da estrutura, em outras palavras, os niveis juridico, politico e ideológico se fundamentam na forma de como se encontram os ho mens com relação a sua participação na propriedade e como se faz o controle dos meios de produção em um determinado contex to social.

As contradições que, historicamente, ocorrem internamente e entre os níveis distintos, dão iugar à mudança, a qual tanto pode ocorrer em nível de superestrutura, como é o caso de mudança de atitudes ou nas relaçōes tecnolögicas a que nos estamos referindo, como a nivel de estrutura, como é o ca so das relações de produção e onde, en última instāncia, deve- 
se concentrar uma estratégia de mudança.

No caso latinoamericano, a mudança perseguida pelo capitalismo, atravēs de modernização, situa-se a nỉvel de superestrutura, ou seja, a mudança de atitudes por parte dos agricultores; considerando as atitudes e as motivações como definidoras da realidade social, é fácil deduzir que atitudes contrārias à mudança são características inerentes ao tipo de sociedade atrasada economicamente ou tradicional.

Em face disto, os estudos acerca da realidade social latinoamericana foram enquadrados dentro do contexto do subdesenvolvimento económico que caracterizava estes países, pois este era reduzido a um estado de atraso tecnológico; en tre essas teses ou interpretações das mesmas, comentar-se-á a quela que, considera-se a mais importante e na qual se fundamenta toda a posterior ideologia modernizante do meio rural. A tese referida é aquela que considerava os países da América Latina como sociedades duais.

Segundo esta concepção, nos mencionados paîses exí tem duas sociedades com características diferentes e, até cer to grau, independentes:

a - Uma sociedade "tradicional", tipicamente agrária, estagna da e retrógada, de origem coloniai; que não muda ou se muda, é lentamente devido a pressões condicionantes exter nas, ou seja, devido a alteraçōes provindas da sociedade "moderna", constituindo um obstáculo ao desenvolvimento econômico; e, 
b - Uma sociedade "moderna", tipicamente industrial, dināmica, progressista e em desenvolvimento, aberta para as mu danças, gerando suas prōprias transformações e constituindo-se, desta forma, em um foco de desenvolvimento econōmico.

Em outras palavras, na sociedade "tradicional", os agentes sociais realizam um número restrito de atividades eco nómicas cuja característica é a baixa produtividade e nela a estabilidade econômica e social mantēm-se por longo espaço de tempo ; na sociedade "moderna", pelo contrārio, os agentes so ciais realizam atividades económicas as mais diversas e com uma alta produtividade, por isso mesmo as mudanças são contínuas.

A este respeito, comenta IANNI (1976:51) "no século vinte, depois da Segunda Guerra Mundial, essa perspectiva ana litica readquiriu prestígio e difusão, passando a ser ampla mente utilizada. Esta nova época de prestígio do abordamento dualista, todavia, foi (e também é) bastante influenciada pelas anālises dos economistas. Estas anālises chegaram às nações latinoamericanas acompanhadas do prestígio institucional e científico conferido pela Organização das Nações Unidas (ONU) e as entidades filiadas a ela, como UNESCO e CEPAL".

Estes dois tipos de sociedade, elaborados pelos teoricos do desenvolvimento econōmico capitalista, são concebi dos como níveis ou estados na evolução social, em que a socie dade "tradicional" é vista como o estado inicial e a socieda- 
de "moderna" como o estado a ser alcançado.

Em vista disso, para GERMANI e LERNER, as socieda des modernas do momento atual, originam-se a partir do progres so tecnológico que se iniciou com a Revolução Industrial acon tecida na Inglaterra no século XVIII; desta forma, as sociedades anteriores e as que atualmente não têm chegado a tecnificar-se, são consideradas como tradicionais.

Para HAGEN e MCCLELLAND, o aspecto econōmico ē mais definidor, ao considerar as sociedades tradicional e moderna, como estados de crescimento económico alcançado pela sociedade nas diferentes épocas histōricas, portanto é possível que as sociedades tradicionais da atualidade transformam-se em mo dernas atravēs do crescimento económico.

E evidente que, ao considerar-se esses tipos de sociedade como estados da evolução social, pressupõe-se que elas existam como unidades independentes no tempo e no espaço. Portanto, os estágios de atraso ou de progresso que apresen tam os paises em processo de desenvolvimento, devem ser identificados e estudados nas caracteristicas internas e particulares a cada um, sem ter que fazer referēncias às relações e$x$ istentes entre tais paises.

Um representante desta corrente, LAMBERT (7974:63) diz textualmente que "o aparecimento de uma sociedade dualista, tal como se encontra hoje em muitos países chamados subde senvorvidos, não é, pois, uma consequéncia inevitável do desenvolvimento econōmico, nem da concentração regional excess 
va desse desenvolvimento: ē antes consequēncia das condições particulares nas quais ele se processa".

Se, para a década de 50, em pleno auge desenvolvi mentista, os cientistas sociais latinoamericanos desenvolve ram uma atitude crítica diante dos modelos teōricos externos, também é verdade que tal atitude não foi mais alēm do que juI gou essencial para aquele momento. Unida a esta critica, fal tou a anāise objetiva e profunda das verdadeiras causas do subdesenvolvimento, a tal ponto que as anālises teóricas e em píricas continuaram tendo como centro de atenção o estudo das sociedades ou estruturas "tradicionais", consideradas como as verdadeiras causadoras do sub-desenvolvimento latinoamericano. A partir deste ponto de vista, podemos adiantar que o esquema conceitual em que se fundamentou toda a estratégia portadora de modernização da a tividade agrícola,partiu, digamos assim, de pressupostos errados, como jā se começa a perce ber ao ser considerados os dois tipos de sociedade, tradicional e moderna, como estados na evolução social.

Deve-se ressaltar que modernização e desenvolvimento são modelos distintos do processo de mudança social, uma coisa não é causa da outra, como supunham os teóricos da modernização que iria acontecer. Se entendermos por modernização o processo pelo qual uma sociedade adota padrões de consu mo, de comportamento, de instituições, valores e idéias de so ciedade mais avançadas; o desenvolvimento, implica mudanças estruturais, que alteram basicamente o perfil de sua estrutu- 
rais, que alteram basicamente o perfil de sua estrutura econô mica e social.

No caso da América Latina, tratou-se de impor, e as sim foi, o primeiro modelo visando a conseguir o segundo, 0 que não chegou a ser realizado por causa do caráter etnocen trista do conceito que se tinha de modernização que, como bem diz COSTA-PINTO (1967:194) "uma sociedade é considerada tanto mais moderna quanto mais se assemelham seus padrões de consumo e de comportamento, seus sistemas de valores e de idéias aos de Londres, Paris ou Nova York, tendo-se por explicitamen te estabelecido, por muito tempo, que esses padrões eram necessariamente modelares".

Já em 1965 STAVENHAGEN comentava sobre o equívoco, erradas e ambíguas que eram as teses que tratavam de explicitar os problemas do desenvolvimento e subdesenvolvimento econômico a, além disso, sua aceitação por parte dos setores intelectuais da região, "ainda que, os fatos desmentissem tais interpretações e os estudos realizados comprovavam sua falsidade, adquirindo tais teses um carāter dogmātico".

Entre essas teses se encontrava, como era de se esperar, a tese da sociedade dual e a este respeito, STAVENHA GEN (1974:117) afirmava que "se é certo que nos países latino americanos existem diferenças entre as zonas urbanas e rurais e, que, se em algumas zonas atrasadas e isoladas, existem gran des latifündios, nos quais as relações sociais e de trabalho entre os camponeses e o proprietário tém todas as caracterís- 
ticas de servidão, tais discrepāncias não justificam o emprego do conceito de sociedade dual pelos motivos seguintes:

a - porque os dois polos são o resultado de um único processo histōrico, e,

b - porque as relações mūtuas que mantém entre si as regiões "arcaicas ou feudais" e as "modernas ou capitalistas", re presentam o funcionamento de uma ūnica sociedade global da qual ambos plos são partes integrantes.

E evidente que o processo histórico e a sociedade global a que se refere o autor, é para o processo de desenvol vimento e expansão do capitalismo mundial e para a sociedade capitalista, respectivamente; processo que no àmbito latinoamericano gerou um polo atrasado ao lado de um polo moderno,em outros termos, a sociedade "tradicional" não é a causa, mas sim uma consequēncia, entre outras, do desenvolvimento capita lista.

Identificar ao subdesenvolvimento como um estado de atraso, pré-existente ao estado de desenvolvimento, significa uma contradição histōrica, pois, é altamente sabido que tanto as regiões desenvolvidas como as atrasadas, são produto da di ferenciação de funções nas relações entre elas, estabelecidas a partir da expansão do sistema capitalista-mercantilista do século XIX, em outras palavras, o que define historicamente o estado de subdesenvolvimento, é o tipo de relações estabelecí das entre os paises capitalistas-mercantilistas e as regiões alcançadas por sua expansão. 
Por outra parte, desenvolver-se uma sociedade signi ficava alcançar um certo nível de progresso, tomando como modelo as sociedades desenvolvidas, modernas e industrializadas da atualidade, para o que seria necessário que, previamente, se eliminassem os obstáculos sociais, políticos, culturais, etc., segundo SANTOS (1977:15), tal modelo de sociedade desen volvida "é o resultado de uma abstração ideológica (porque for mal e, portanto, a-histōrica)".

Segundo o autor, se os modelos conhecidos de sociedades desenvolvidas eram - e nisto concorda com COSTA-PINTO, os Estados Unidos, Europa, Japão e União Soviética, a cujos niveis pretendia-se chegar, era pretender que, na América Latina, se repetisse a experiēncia histōrica desses paises, em outros termos, seria possivel reduzir o desenvolvimento a um modelo formal cujo conteúdo era passível de variação histórica.

Esta suposição, segundo SANTOS, não tem nenhuma validade científica, porque se funda em princīpios não histōricos, ou seja, não há nenhuma possibilidade histórica de que se constituam sociedades que alcançem o mesmo estado de desen volvimento tal como o daquelas já desenvolvidas.

Isto é assim, explica SANTOS (1977:16), "porque o tempo histórico não é linear, isto é, não há possibilidade de que uma sociedade se desloque até etapas anteriores de sociedades ja existentes. Todas as sociedades movem-se paralelas e juntas até uma nova sociedade. Por exemplo, as sociedades 
capitalistas desenvolvidas correspondem a uma experiência his tōrica completamente superada, cujas condições historicamente especîficas não se podem repetir hoje em dia".

Logo, para SANTOS, resulta impossível atingir uma explicação dos problemas latinoamericano caso se continue 1 imitando o enfoque às resistências econōmicas, sociais, polîti cas, culturais e instituições da sociedade "tradicional". Por tanto, deve-se centralizar a anāi ise, não em uma relação abstrato-formal entre dois estāgios (tradicional v.s. moderno, ca pitalismo v.s. feudalismo), mas, sim, no modo de ser destas so ciedades concretas, historicamente formadas, que são as sociedades subdesenvolvidas.

Para terminar, SANTOS afirma que o desenvolvimento enfim, não é uma questão técnica, nem tão pouco, uma transi ção dirigida por tecnocratas e burocratas até uma sociedade de finida como modelo, mais ou menos fundamentado na abstração formal de experiēncias passadas.

Vé-se, pois, segundo o comentado anteriormente, que a sociedade dual era representada como uma suposta confrontação entre as relações sociais de produção feudais, todavia vi gentes na Amērica Latina e as relações sociais de produção ca pitalistas, como tambēm a forma em que dita tese se constituiu em um instrumento de penetração, pois, logicamente, ao ser con sideradas as primeiras como um obstáculo ao desenvolvimento, deveria ser substituidas pelas segundas e assim, dar lugar ao capitalismo progressista, desenvolvido pelas classes sociais 
dominantes em favor do pais como um todo.

Após esta perspectiva teórica, passar-se-ā de imediato ao estudo da estratégia política da modernização.

\section{2 - A Modernizagão e a Redengão Camponesa}

Se a evolução social era considerada, teoricamente, como a passagem de um estado tradicional para um moderno, res taria agora, explicar como se dá esta passagem e como isto po deria acontecer dentro do contexto latinoamericano.

E assim, e em harmonia com a exigência objetiva do capitalismo, que se desenvolve na América Latina toda, uma es tratégia ideológica de mudança social definida em termos de mo dernização e que consistia na transformação de uma sociedade do estado tradicional para o moderno, ou seja, na eliminação daquelas formas arraigadas que impediam um desenvolvimento ca pitalista acelerado, tanto a nível de relações de produção co mo a nỉvel de organização e ideologia.

Este conceito de modernização, tal como é empregado nesse contexto histórico e ao qual "jā nos referimos anteriormente, é sinōnimo do conceito de desenvolvimento, pois, supõe que a introdução do progresso técnico resulta em um crescimen to da renda real que beneficia igualmente a todas as camadas de população.

Segundo esta perspectiva, a modernização signifi ca mudanças económicas, politticas e sociais que, segundo os 
fundamentos da sociedade dual, podem ser definidos antes que ocorram em uma sociedade, pois, as sociedades desenvolvidas e modernas da atualidade jā passaram por esta experiência, portanto, nas atuais sociedades subdesenvolvidas, é lógico que o corra o mesmo processo, sempre e quando sejam eliminadas as características tradicionais internas.

Mas, acontece que, no contexto da América Latina, de vido à sua situação de dependēncia estrutural, são as classes dominantes que controlam o sistema produtivo e politico, as que se apropriam dos excedentes que o desenvolvimento capitalista produz e, por isso, não se eleva em momento algum o nĩvel de vida dos trabalhadores, embora as organizações trabalhistas te nham conseguido algumas reinvindicações salariais.

Segundo as tendēncias histōricas do desenvolvimento e da mudança na América Latina, a modernização não significa uma condição suficiente para atingir o desenvolvimento integral ; pelo contrārio, a modernização tecnolōgica coopera para uma maior apropriação por parte do sistema internacional. De fato, tal política tem estimulado o processo de expoliação das massas trabalhadoras do meio rural; no setor agrícola, $\underline{e}$ la tem aumentado o nūmero de desocupados que não podem ser a sorvidos pelo setor industrial devido ao crescimento deformado que se apresenta por causa da dependéncia externa dos países.

Debaixo desta perspectiva da modernização, criou-se em junho de 1948, a Comissão Econōmica para a América Latina 
(CEPAL), por influência da Organização das Nações Unidas (ONU) e da qual forma parte, tendo como meta principal a de promo ver o desenvolvimento econômico da mesma.

A solução dos problemas, segundo a CEPAL, estava na diversificação das economias dos paises latinoamericanos, na industrialização e desenvolvimento de seus recursos naturais, e no melhoramento e modernização de sua produção agrícola. Em relação a esta última, mostrava que o desenvolvimento da agri cultura achava-se retardado, entre outras causas, pela insuf $\underline{j}$ ciência de conhecimentos técnicos e por falta de máquinas e ferramentas agrícolas.

Como podemos observar, a CEPAL dá ènfase ao aspecto da modernização da produção agrícola e ao baixo nỉvel de conhecimentos técnicos por parte dos agricultores.

Para solução destes problemas, a CEPAL (1948:17) re comendava "empreender um estudo preliminar acerca dos elementos, meios e facilidades, técnicos e administrativos, dos paises da América Latina e das atuais possibilidades a respeito, incluindo-se referēncias ao adestramento técnico,devendo ser organizadas listas de organizações que pudessem prestar colaboração tēcnica, incluindo-se as instituições de carāter internacional criadas com esse objetivo; as instituições nacio nais que tivessem oferecido facilidades com o mesmo fim e os principais organismos privados que pudessem prestar semelhante ajuda".

Desde este instante e através de um instrumento ins 
titucional, aprovado pelos governos de vinte repūblicas latinoamericanas e, alēm disso, com a "cooperação desinteressada" da ONU, inicia-se uma das estratégias ideolōgicas mais sensacionais em toda a história do desenvolvimento capitalista na América Latina.

Existia uma sociedade "tradicional" que devia ser transformada em moderna ; existia um setor agrícola atrasado que deveria ser aperfeiçoado e para se conseguir isto, contava-se agora com a "benevolência e boa vontade" do governo nor teamericano o qual punha à inteira disposição de nossos gover nos, toda a sua capacidade técnica, administrativa e financei ra, elementos básicos para iniciar um processo de desenvolvimento económico que nos colocaria em lugar de destaque ante o mundo moderno e desenvolvido.

Contando com esse prestigioso "aval" que representa va a ONU no mundo capitalista e por intermédio da organização de Estados Americanos (OEA), instrumento de penetração capita lista na região, os governos latinoamericanos aceitam e põem em prática, sem nenhuma prévia discussão, tudo o que, em matéria de planificação económica, para o setor agrícola, ihes chegava dos centros de decisão com sede, logicamente, nos Estados Unidos.

Como bem disse LOSADA (1976:165), "(...) os representantes conservadores e reformistas das duas Américas trocam idéias e iniciam a elaboração de programas agrārio, é nas reuniões da Organização dos Estados Americanos (OEA), onde e- 
les adquirem forma definitiva. Lá, precisamente nesse centro onde se concentram, sob a direção dos Estados Unidos, as 1inhas bāsicas da política latinoamericana das classes dominantes em ambas Américas, lá se antecipam e proclamam as idéias diretrizes que a nação do norte lançará como linha agrāria pa ra a Amērica subdesenvolvida".

A estratégia modernizante foi seguindo dois caminhos em sua implementação:

a - via direta, isto é, através do Programa de Cooperação Téc nica dos Estados Unidos; mediante as constantes visitas à região das famosas "missões técnicas", que em viagem de "boa vontade" se tornaram características na década de 50 ; tais missões eram integradas por personagens qualificadas como os mais entendidos em matéria de planejamen to agrỉcola.

b - via indireta, em vista de uma maior difusão, ou talvez, para não ferir susceptibilidades nacionalistas, a moderni zação do setor agrĩcola passou a ser realizada no prōprio paîs, por intermédio de agências ou departamentos de extensão agrícola criados para tal fim nos Ministérios de Agricultura e nas Faculdades de Agronomia das Universida des, seguindo sempre as diretrizes que segundo os orga nismos internacionais (OEA, FAO, IICA e outros) eram as mais convenientes para cada região.

Desde então, nos países latinoamericanos, as Faculdades de Agronomia passaram a desempenhar um papel fundamen - 
tal na realização da estratēgia modernizante, convertendo - se em autēnticas "fábricas" de agentes da mudança tecnológica e, alēm disso, em sedes de numerosos acontecimentos de carater in ternacional, onde os temas preferidos para serem analisados e discutidos eram a educação agrícola, a extensão agrīcola,o de senvolvimento das comunidades, etc.

Foi assim que em 1958, celebrou-se no Chile, a Primeira Conferência Latinoamericana sobre Educação Agrīcola Superior, supervisionada pela FAO - IICA e na qual, segundo o IN FORME (1958:19-21), consideravam-se as Faculdades de Agrono mia da América Latina como "instituições educativas que teriam um papel fundamental para desempenhar no desenvolvimento da gricultura e da vida rural; seus fins e seus principios deviam abranger uma concepção mais ampla da responsabilidade educativa das Faculdades em quanto propiciavam o desenvolvimen to científico, técnico, econōmico e social".

Entre os princípios aprovados que refletiam as condições e necessidades da época e que deviam guiar ao desenvol vimento da Educação Agrícola Superior, entre outros, mostra vam que a Faculdade de Agronomia, como parte integrante da Universidade, devia ser uma instituição destinada a despertar e estimular o espírito, o método e a ambição científicos, con siderando-se assim como representatividade da Universidade em suas funções básicas de adestramento e investigação, destinadas a produzir o bem-estar da população rural do país inteiro. $\bar{A}$ medida que a América Latina orientava-se para 
o desenvolvimento técnico e científico que caracterizava a ēpoca, a Faculdade de Agronomia deveria situar-se na vanguarda da promoção de todas as atividades dirigidas a alcançar este objetivo no campo da agricultura e da vida rural.

Em relação à preparçaão de seus profissionais,estes deviam atuar como empresários e administradores dos recursos na turais da nação, participando ativamente no desenvolvimento $\underline{e}$ conômico do paîs e na aplicação das ciēncias e tecnologia na agricultura.

Em sintese: faculdades e agrónomos a serviço da tec nologia agrícola capitalista.

Com a criação da CEPAL e com a celebração da Prime ra Conferēncia Latinoamericana de Educação Agrícola Superior, construiu-se, por assim dizer, as bases ideológicas para a in tervenção modernizante no meio rural latinoamericano; só fal tava agora o desenvolvimento de um processo que traduzisse em prātica e esta foi também um ponto visado pela CEPAL: a extensão rural ou agrícola.

3 - Extensão Rural ou Extensão do Capitalismo?

Deve-se esclarecer que até os fins da década de 50, a disciplina que tratava sobre os aspectos sociais, culturais etc. da população camponesa, ministrada nas faculdades de Agro nomia, era a Extensão Rural ou Agrícola. Sendo considerada co o fundamental na constituição do currículo e na modernização 
da agricultura, a Extensão se converteu na razão de ser para os que saiam das Faculdades de Agronomia.

Além disso, nos numerosos encontros que se realizavam com relação a assunto latinoamericano, a Extensão Rural e ra o principal centro de interesse, onde se poderia encontrar a solução final dos problemas da agricultura e da população camponesa.

Em decorrência disto, apareceram: a celebração em Costa Rica (1949) do Primeiro Seminārio de Extensão Rural, se guido pela celebração no Brasil (1959) do Seminārio Sulamericano de Extensão Rural e no México (1963) houve o Seminārio para a Zona Norte da América Latina, todos supervisionados pe la FAO e não pretendiam outra coisa senão a reafirmação dos princípios da Extensão Rural norteamericana e com estratégias traçadas antecipadamente pelos organismos patrocinadores.

A Sociologia Rural, como tal, só passou a tomar par te nos currículos da maioria das Faculdades de Agronomia, na década de 60 , quando jā era evidente o fracasso dos programas de extensão, mais, isto não quer dizer que com a inclusão des ta ciência social na formação do agrônomo, chegaria-se a uma melhor interpretação da problemática rural e, portanto, a reconsideração dos princỉpios e objetivos da Extensão Rural, ao contrārio, os princīpios de Sociologia aplicados tambëm vinham impregnados da ideologia capitalista modernizante.

Como afirmava IANNI (1976:43), "no presente, em especial depois da Segunda Guerra Mundial, a influência predomi 
nante é exercida pela Sociologia dos Estados Unidos. Portanto, a hegemonia norteamericana sobre a América Latina não se limita às relações econōmicas, politticas e militares. Ela se extende tambēm à esfera da cultura artística e científica".

Se o que se pretendia era uma mudança tecnológica, os objetivos fundamentais dos programas de Extensão Rural na América Latina, eram atingir uma modernização da agricultura, mediante a incorporação de uma técnica agrīcola avançada. Por isso o papel a ser desempenhado pelo Agente de Extensão ou Ex tensionista reduzia-se a transmitir à população camponesa, uma sērie de conhecimentos tecnológicos aprendidos durante o processo de sua formação e posterior prātica profissional.

Devido à sua importāncia, era necessāria uma participação mais dināmica da Extensão Rural no desenvolvimento so cial e econômico dos países, a fim de "melhorar as condições de vida do produtor rural e de sua familia e o crescimento ge ral da economia".

Desta forma, seguindo os principios de mudança tecnológica, nos meses de novembro e dezembro de 1970 se reali zou no Perū, a Conferéncia Técnica de Extensão Agrícola e Juventude Rural, sob os auspícios da FAO e o Programa das Nações Unidas para o Desenvorvimento (PNUD) e já de inīcio, nos discursos de abertura, os principais promovedores da conferē cia, segundo o INFORME FINAL (1971:8-10) manifestavam "que era aspiração da FAO que a Conferéncia, que reunia pela primei ra vez delegados dos serviços de extensão de todos os paises 
ses da região,produzissem uma maior adequação destes serviços para as necessidades e situações do amplo setor de camponeses e pequenos agricultores".

Manifestava também "que o desenvolvimento da Amērica Latina deveria ser tratado como um processo de mudança e trutural que implicaria não só o a umento da produção, como tam bém, modificações em suas instituições. Era preciso, outrossim, dar-se um impulso maior ao processo de Reforma Agrária In tegral, com a finalidade de eliminar os sistemas de latifún dio e minifūndio". Eram estas as aspirações da FAO por inter médio de Enrique Summer, representante do Diretor Geral de tal instituição.

Estava claro que a modernização da agricultura atra vēs dos serviços de extensão agrícola, deveria ser dirigida à quele amplo setor de agricultores, camponeses e pequenos lavradores, que não estavam capacitados para receber a nova tẹ nologia, ou seja, aos supostos representantes da sociedade "tradicional"; por outro lado, suspirava-se por uma Reforma Agrária Integral que eliminaria os sistemas ou restos feudais, demonstrava o interesse de estabelecer ou fortalecer as relações de produção capitalista, pois, as primeiras, como jā era sabido, eram um obstáculo ao desenvolvimento; poderia ser, tam bém, que tal iniciativa como opinam vārios autores, tinham co mo intenção evitar possiveis tensões sociais no meio rural e que se transformariam em movimentos revolucionários ao estilo cubano. 
Outro patrocinador da Conferência, o representante do PNUD, o peruano Enrique Ezcurra, segundo o INFORME FINAL (1971:11), manifestava seu convencimento de que "a capacita ção dos agricultores era o elemento chave do desenvolvimento". Aceitando a crença "já manifestada por Rāul Prebisch e outros notáveis economistas do Continente, de que sem o uso maciço dos conhecimentos científicos e tecnológicos, não haveria desenvolvimento agrícola e que sem um avanço agrícola em todos os nîveis, desde o humilde agrupamento até as sedes ministe riais, tal uso da ciēncia e da tecnologia seria impossivel". Já com estas idéias preconcebidas, pode-se bem imaginar o restante do planejamento contido no Informe Final, on de, entre outras coisas, procura justificar toda a filosofia da Extenção Rural, utilizando, às vezes, claros conceitos mal thusianos e onde se deixa ver claramente a posição que deveriam assumir e sustentar os governos, as multinacionais e os organismos internacionais interessados na problemática rural latinoamericana.

Desta forma, os governos deveriam reconhecer o fato de que o desenvolvimento econōmico dos países da região não po deria consolidar-se sem antes ter resolvido numerosos problemas que concerniam, direta ou indiretamente, ao setor agropecuário e que as atividades deste setor caracterizavam-se por sua escassa produtividade, resultante de uma agricultura tradicional, sobretudo de subsisténcia, na qual a moderna tecnologia estava apenas em vias de introdução. 
As multinacionais, fazia ver, que os novos métodos e técnicas para incrementar a produtividade, reclamavam o uso ca da vez mais intensivo de equipamentos e insumos de alta efi ciēncia, tais como sementes, fertilizantes, pesticidas, alimentos concentrados, remédios para o gado, implementos e ferramentas. Aconselhando-se que para obter o desenvolvimento que buscavam, era necessārio que estes equipamentos e insumo essenciais fossem acessiveis e estivessem ao alcance dos camponeses nos próprios centros de produção.

Finalmente, para os organismos internacionais, em vista da escassez de profissionais da agronomia na área de Ex tensão Rural a Conferéncia julgava conveniente solicitar a as sistência externa e onde, organizações internacionais tais co mo a FAO, o Fundo Especial das Nações Unidas (FENU), o Banco Interamericano de Desenvolvimento (BID), entre outros, poderiam proporcionar a assistência técnica necessāria representą da por consultores qualificados, bolsas de estudos para a for mação do pessoal local, etc.

Diz PINTO (1972:43) que "diante deste conceito de mudança, ou seja, a nîvel de estrutura, se a Extensão Rural é planejada como estratégia de mudança e uma dinämica do desenvolvimento rural, parece evidente que não se pode aceitar como sua, a estratégia de modernização, dadas as suas deficiēncias teórico-práticas e seu fracasso como experiēncia de mudança".

Na realidade, depois de mais de vinte anos que foi 
posto em prática o modelo de mudança tecnológica, as condições de desigualdade econômica e social não só têm-se mantido constantes, como tambēm, em alguns aspectos, tornaram-se mais agudas, levando as grandes massas menos favorecidas de meio ru ral a uma situação de incrīvel exploração e misēria.

Diante das crīticas, os teōricos da modernização e da transformação tecnológica consideram, que se a Extensão tem fracassado ē devido, segundo o INFORME FINAL - FAO (1971:62) ao fato de que "os serviços de Extensão estão administrados e su pervisionados por profissionais que nunca tiveram oportunidade de obter uma orientação atualizada no campo da Extensão em termos de capacitação e experiēncia".

A maneira de autocritica, entre os representantes responsāveis pelo fracasso dos programas de Extensão Rural, en contram-se os prōprios extensionistas, sociōlogos, educadores, politicos, economistas, pēritos internacionais e outros, por uma ou outras razões, sendo que a omissão do aspecto social em tais programas foi o denominador comum.

Tanto é assim, que, quando se elabora um novo con ceito de Extensão, INFORME FINAL - FAO (1971:41), o extensio nista é definido como "um agente de mudança tecnolōgica e social, entendendo-se por mudança social, a transformação do or denamento ou estrutura da sociedade em todos os aspectos". A lém de nos dar um conceito de mudança soçial bastante ambíguo, em momento algum, o INFORME FINAL explica, ou dá a entender a forma em que se dā a transformação da estrutura social. 
Um exemplo recente e por demais patético do que pode chegar a ser uma estratégia ideológica dirigida a fortalecer as relações de produção capitalista no meio rural latinoamericano, e, resumindo tudo o que se disse anteriormente, foi a famosa Revolução Verde, destinada segundo seus planejadores e patrocinadores, a "erradicar a fome, a carestia e desnutrição no Terceiro Mundo, por meio da aplicação da tecnologia".

Mas, na realidade, a erradicação da fome nos países subdesenvolvidos era o que menos interessava e sim, iniciar to da uma estratégia orientada à eliminação de um setor da Refor ma Agrāria, o qual vinha contribuindo de forma significativa na produção de alimentos básicos para a população do México.

Esta situação significava, para os observadores nor teamericanos, uma clara ameaça às bases da iniciativa privada no setor agrícola; por isso era preciso um esforço destinado a prestar ajuda às classes dirigentes mexicanas na organiza ção de um setor agricola capitalista. Tal setor recebeu apoio em termos de capital, assistência técnica, investigação, etc, razão pela qual, o setor da Reforma Agrāria não foi capaz de assimilar o impacto capitalista, levando seus beneficiários, os camponeses mexicanos, a retroceder em sua marcha para o bem estar social.

Foi assim que seu executor Norman Borlaugh (Prêmio Nobel da Paz) e sua equipe de pesquisas foram designados para um programa, patrocinado pelas Fundações Rockefeller-Ford, de desenvolvimento de sementes de milho, sorgo e trigo, mais 
conhecido pela sigal HYV (High-Yielding Variety): varieda des de alto potencial produtivo - capazes de alcançar altos niveis de produtividade quando são usadas sob excelentes condições ecológicas e mediante aplicação de avançadas técnicas gerenciais e o mais moderno equipamento e maquinaria.

Se o que desejava a Revolução Verde era prover alimentos para o consumo doméstico de grandes massas da popula ção, por trás de toda esta retórica havia algo mais, como seja, acentuar ainda mais as desigualdades sociais em um meio rural jā bastante castigado pela indiferença oficial como $\bar{e}$ o mexicano.

Para FEDER (1977:52) "ainda quando a Revolução Verde significou um grande éxito em termos de produção de grandes quantidades de trigo, milho e sorgo, ao mesmo tempo deu causa a um declínio contínuo do status económico, social e politico das massas e um aumento no diferencial de renda, saūde, nutrí ção, vestuārio e educação entre as classes sociais no setor agrícola do México".

E notōrio que, quando se chega a uma alta produtivi dade na produção agrícola como foi a conseguida pela Revolu ção Verde, faz com que o emprego de tecnologia seja rendoso, dando lugar a um aumento na procura de todos os tipos de ins mos agrīcolas; esta situação é aproveitada por grandes firmas agrocomerciais, jā que se constituem nas ūnicas que podem ofe recer tais insumos; assim, as corporações multinacionais em seu papel de fabricantes dos mesmos, interessavam-se por este 
tipo de "revolução agrīcola" muito mais do que os países interessados na questão.

Por isso, na opinião de FEDER a Revolução Verdee sō um dos elementos da estratégia geral de penetração das nações industriais na agricultura do Terceiro Mundo.

Julga-se agora, ser importante observar que a estra tēgia de modernização da agricultura pela extensão ou difusão de tecnologia, desempenhou um papel importante na posterior di fusão das HYV, pois em seu redor, os Estados Unidos organiza ram um eficiente programa de modernização em cooperação com os governos dos paises subdesenvolvidos, para os quais a distribuição de sementes e a assistēncia técnica "gratuita" por parte dos Estados Unidos, oferece uma condição muito vantajosa e uma oportunidade que não se poderia deixar escapar,a fim de se obter o autoabastecimento em produtos alimenticios.

Mas para FEDER (1977:56) a realidade è outra, o autor ē enfático ao afirmar que "(..) a Revolução Verde não ē um programa de distribuição de sementes e sim um pacote tecno lógico, uma vez que a utilização adequada da HYV requer o uso quase obrigatório de altas inversões de capital em instalações de irrigação e equipamentos, maquinaria sofisticada e assis tência técnica e gerencial experimentada; por isso o pácote de HYV estā destinado principalmente para ser usado por produ tores comerciais em grande escala e não por produtores camponeses".

Escolheu-se o exemplo mexicano porque, além de sua 
grande repercussão no mundo inteiro, nos proporciona um marco de referência de uma situação que bem pode acontecer em todo - contexto latinoamericano quando a empresa privada é obstacú lizada por alguma forma de empresa coletiva. Observou-se como um programa de melhoramento de sementes com "fins humanitá rios", se converte no eixo em torno do qual giram outros fato res importantes como a educação, a pesquisa e a extensão rural desenvolvidas em sua maior parte, pelas instituições universi tārias do pais.

Esses três fatores, deve-se esclarecer, não atuam em forma isolada, mas formam uma só "unidade que se liga com toda uma estratégia previamente preparada pelos interesses económicos das corporações internacionais e grupos agrocomerciais que monopolizam a fabricação e distribuição dos insumos referidos por FEDER. Neste sentido, a universidade entra no ciclo de reprodução capitalista.

4 - A Universidade como Produtora de Reprodutores

Diante desta situação, a politica governamental nos países subdesenvolvidos, uns mais, outros menos, é dirigida a superar o atraso económico dessa "realidade" observada pelos teóricos da modernização, mediante uma mudança cujo modelo a seguir é a própria realidade, ou seja, o modelo da sociedade desenvolvida; de modo que as ideologias a serem difundidas e as politicas a serem implantadas pelas classes dirigentes re- 
presentam, implicitamente, atitudes e comportamentos modernizadores.

Se a modernização é atribuĩda às classes dirigentes ou às elites dominantes, é lógico que as atitudes tradicionais são atribuî́das às massas, em especial às massas atrasadas, re sistentes às mudanças; por isto, a necessidade do Estado proporcionar as condições mīnimas para que a expansão da ideologia dominante chegue às massas camponesas do setor "tradicional".

A aceitação e adoção de determinadas ideologias externas, pelas clases dominantes dos paises subdesenvolvidos, segundo Vasconi, citado por SILVA e SONNTAG (1976:113) "implica basicamente em duas funções principais:

a - levantar toda uma superestrutura a qual legîtima sua relação de classe dominante local com o "centro dominante internacional".

b - log•, jā na ordem interna, legitimar sua prōpria posição dominante, ao operar como instrumento de dominação e meio de distinção com relação às classes e grupos subordina dos".

Assim acontece que, atendendo-se a estas funções, as classes dominantes por intermédio do aparelho governamental, im põem sua ideologia em todos os organismos e instituições do pais, sendo que as instituições educativas e de pesquisa estão em primeiro plano, devido à importáncia de suas āreas de trabalho na planificação do desenvolvimento, como são os "re- 
cursos humanos", científicos e técnicos.

Desta forma, as Universidades e outros centros de en sino e pesquisa são conduzidos sūtil ou agressivamente, a ela borar programas educativos e de desenvolvimento que têm como fim a configuração de um sistema social acomodado às sociedades subdesenvolvidas. Tal sistema, em todo caso, e o que garante e fortalece os interesses das classes dominantes local e estrangeiras.

No caso específico da universidade venezuelana, SIL VA e SONNTAG (1976:166) afirmam que "(..) devemos dizer com grande apego à verdade que nossas universidades, não obstante sua beligerāncia politica progressista, e não poucas vezes rea? mente revolucionāria, especialmente ao nível de suas massas es tudantis, tem atuado como agentes objetivos do imperialismo norteamericano, e, o que é mais grave, muitissimos professores, militantes políticos, têm contribuído em não pequeno grau para facilitar a difusão de ideologias encobertas por uma neutralidade cientifica que atentam contra a nacionalidade e a liberdade".

Com relação a este ponto, é conveniente ressaltar que em 1968, o Professor Rodolfo Quintero viu-se na obrigação moral de denunciar, por meio de sua conférencia "Espionagem So ciológica na Venezuela", que em 1964 o Centro para Estudos do Desenvolvimento (CENDES), uma dependéncia importante e fundamental da Universidade Central da Venezuela (UCV), estava interessada em colaborar com o Centro para Estudos Internacio - 
nais (CENIS) do Instituto Tecnológico de Massachussets (MIT), dirigido por Max F. Millikan, em um estudo sobre a Venezuela ao qual se deu o nome de "Estratégias para a Mudança Social". Até este ponto, tudo bem, mas acontece que os membros do MIT são colaboradores a serviço da Agência Central de Inteligên cia (CIA) americana e que o CENIS foi fundado em 1951 devido a um importante donativo da CIA e da qual Millikan foi seu Di retor Auxiliar, em Washington, segundo documentos citados por SILVA E SONNTAG (1976:144).

Outra consequência resultante da apropriação da uni versidade por parte da ideologia capitalista é a manifestada discriminação das ciēncias sociais com respeito às ciēncias de caráter experimental no seio da mesma.

Referindo-se especificamente ao caso venezuelano, Ma za, citado por SILVA e SONNTAG (1976:158) diz, entre outras coi sas, "(...) em nosso paîs, quando se fala de ciēncia e de ciên cias reduz-se a amplitude dos objetos aos fenomenos físicos, naturais, que podem ser observados e experimentados, fazendo exclusão expressa ou tácita dos fenómenos sociais, da vida do homem em sua relação com o homem".

Tanto é assim que o Conselho de Investigações Científicas e Tecnológicas (CONICIT), organismo que lidera toda a ção do desenvolvimento cientîfico e tecnológico a nível nacio nal, reserva toda a importāncia às ciēncias da natureza e suas aplicações tecnológicas, não dando importāncia ou relegando a um segundo plano, as ciências cujo objetivo seja a sociedade ou o homem. 
Esta subestimação ou discriminção em prejuĩzo às ciēncias sociais, segundo MAZA, emergem de fontes ideológicas e se projetam no ámbito dos conflitos sociais. Talvez se deva isto, ao fato de as ciências sociais coloquem em relevo a desigualdade estrutural das classes, convertendo-se seu con teúdo revolucionārio em um constante perígo que ameaça as bases do sistema estabelecido, e, por isso, a negativa de seu ca ráter científico.

Devido a isto, considera-se conveniente esclarecer, que na maioria dos casos, os cursos ministrados têm um conteú do cientificamente vālido; porēm, se o ensinamento têm uma fun ção reacionäria, não se deve ao fato de as ciēncias serem ensinadas de uma ou de outra forma, mais sim, deve-se às prōprias estruturas do ensino, de modo que, em relação ao papel a ser desempenhado pela Universidade, que é o que interessa ter em mente, no dizer de RAUCIERE (1971:24) ē que "na anālise da universidade, a 'ciência' e a 'ideologia' são inexistentes como categorias opostas; e na Universidade, a questão não ē a ideologia, mas a ideologia das classes dominantes".

Voltando ao assunto anterior, se o papel do Estado é o de proporcionar as condições para que a modernização chegue ao setor atrasado, é evidente que a Universidade e, no caso, especificamente, a Faculdade de Agronomia, desempenha um papel importante na obtenção dessas condições, pois, dela saem os agentes da modernização através dos principios da extensão rurai. 
Para PINTO (1972:24-26) "a educação, tanto formal como informal ou extraescolar, é parte de um amplo processo de socialização, existente em qualquer sociedade, mediante o qual se transmite dentro de uma geração, conhecimentos, habilida des, hābitos, costumes, atitudes, etc.". Desta forma, continua dizendo o autor, a ação educativa da extensão agrícola, na da mais faz senão repetir o modelo de socialização dominante na sociedade latinoamericana. O extensionista é, em parte,um produto deste modelo e inconscientemente repete em sua atividade este modelo.

Indubitavelmente, como jā assinalado antes, se a po lîtica educacional apoiada pelo Estado está dirigida à transmissão da ideologia dominante, supõe-se então, uma atitude re ceptiva por parte dos alunos dos conteūdos programáticos. Ao final da carreira, o estudante mostra-se um "ser parcial", pa gando o preço social de não compreender a estrutura da sociedade em que vive.

Desta forma, considerando toda esta problemática universidade - extensão - agrónomo, procurando um novo rumo para a concepção do papel da universidade e do agrónomo que deixa suas classes, em maio de 1978 , realiza-se em Maracaibo, Vene zuela, a VI Conferéncia Latinoamericana de Educação Agrícola Superior, sob os auspícios da Associação Latinoamericana de $\underline{E}$ ducação Agrícola Superior (ALEAS).

Na mencionada Conferéncia reconheceu-se que, em nos sos sistemas científicos e tecnológicos, existia uma subvalorização implícita do meio rural, por considerá-lo atrasado, 
pouco organizado, primitivo, incomodo, ilhado, indesejāvel, sem renda, afetando este complexo, inclusive a ati-tude dos que preconizavam a educação agropecuāria e provocando um insensĩvel fenōmeno de "urbanização" das instituições de educação agrícola superior.

Na opinião dos participantes da Conferéncia, era ne cessārio criar uma educação agrícola superior que servisse pá ra produzir novos grupos criticos de agentes de mudança do de senvolvimento económico e politico; que propugnasse pela estruturação de um sistema de cooparticipação na tomada de deci sões e pela transformação de nossa triste realidade; uma edu cação que ao conhecer e analisar a realidade, a transformasse e não a disfarçasse para conservā-la como tinha vindo até o momento presente: uma educação polîtica, concreta, científica e nacionalista.

Reconhecia-se, além disso, que a Universidade tinha sido utilizada como "fábrica" de assalariados especializados, tal era a interferência do poder, mediante a qual se institucionalizavam, controlavam e monopolizavam os recursos educati vos, favorecendo a uma minoria da população. Esta minoria era a que podia ter acesso à educação e, portanto, para obtenção de diplomas, títulos e certificados, que os credenciavam como bem instruidos ou capacitados para ocupar melhores posições na estrutura do sistema social, com a finalidade de diri gir, manejar e manter o tal sistema, que deixava uma maioria na miséria, marginalizada e explorada. 
Quanto à formação do agrônomo, era conveniente, segundo a ATA FINAL (1978:III-B.7.1) "conseguir um profissio nal em cujo perfil apareça um adequado equilíbrio entre seus conhecimentos tecnológicos e sua relação com a estrutura social na qual trabalharā e da qual farā parte".

Segundo a ATA FINAL (1978:III-B.7.1) "a ênfase dada à extensão rural como campo de ação de nossos formados, obrigava a reformular bem fundo o tradicional método da educação informativa, tecnológica e sua mera relação utilitária, que elimina o homem social do esquema que se propõe ao estu dante dentro de uma concepção cientîfica do homem e aî incluir o necessārio dominio das ciências agrīcolas". Sobre este fun damento "dever-se-ia propor um método que conseguisse fixar o estudante dentro da repercussão que sua técnica teria em toda a sociedade e na qual influiria a estrutura social, de forma reciproca".

Tais interpretações julgaram o papel difuso que a $\underline{U}$ niversidade tem tido com relação às tentativas de desenvolvimento por parte dos paises latinoamericanos, o qual tem des pertado o interesse de muitos estudiosos do problema. E assim que se discute se os esboços curriculares e seus conteú dos, são orientados a fim de que os educandos adquiram uma for mação integral e não uma formação mecanicista-tecnicista ; se as áreas de estudo estão integradas para atingir uma compreen são global de um determinado problema ou se atuam como compar timentos estanques, etc. 
Qualquer tipo de técnica, por mais sofisticada que seja, segundo YOPO se dilue historicamente se, em sua aplicação, não se considerar a dimensão social, de modo que a thiver sidade, em vez de ensinar tanta técnica, deveria preocupar-se um pouco mais em formar um produto que em seu agir tenha como meta vital ao homem concreto e não um homem abstrato e em no $\underline{s}$ so continente hā muitos homens concretos, despojados ou marginalizados de qualquer sistema de participação e de justiça so cial.

Continua dizendo YOPO $(1978: 3)$ que "o produto que sai da Universidade tem uma marcada essēncia mercantilista e isto acontece porque a estrutura socioeconómica está assim or ganizada e sendo a Universidade, a educação em geral, um produto de tal estrutura, não se pode esperar outra coisa senão a formação de profissionais alienados, neutros ou deformados em sua maneira de encarar a realidade social".

Concorda-se pois, com o referido autor, o sistema educativo não pode ser visto, nem muito menos analisado como um sistema isolado, mas, pelo contrário, este encontra-se estrei tamente relacionado com as estruturas económicas, sociais e politicas de cada sociedade.

Para NERY (1978:18), "as orientações de mudança so cial não só provēm de interesses estrangeiros, como também por interesse de alguns setores de nossa estrutura social,que pro piciam a introdução e implementação de valores, atitudes e crenças de acordo com os interesses dos que nos exploram. 
Alguns dos meios para conseguir-se este doutrinamento politico e social é representado, entre outros, pelo sistema educativo formal, a tecnologia importada e os modernos meios de co municação de massas".

Quanto ao sistema educativo, continua afirmando NERY (1978:19) "tem sido utilizado pelas classes dominantes pa ra socializar nossa juventude de acordo com uma politica fun damentada em um desenvolvimento e modernização à moda ocidental (...). Nosso sistema educativo está orientado para prepa ração de indivî́duos para o processo económico industrial, para um sistema de vida urbana das classes médias, copiado de modelos superados e alheios à nossa realidade".

Neste sentido, considera o autor, que o sistema educativo tem uma dupla função:

a - a de socializar, através da qual se penetra a ideologia dos setores dominantes em busca de um consenso que legitime sua situação e,

b - a instrumental, ou seja, a seleção e capacitação do pessoal necessário para o desenvolvimento do estilo previamente exposto.

Isto leva, segundo o autor, necessariamente no enfo que dos chamados "recursos humanos" dentro de um marco de referéncia do capitalismo industrial, o qual preconiza a difu são do racionalismo e da modernização como o ūitimo objetivo de socializar os indivíduos, predispondo-os para a aceitação de atitudes favorāveis à manutenção do "statuquo". 
A forma e o grau em que toda esta estratégia modernizadora tem focalizado na configuração de meio rural venezue lano, será o tema a tratar no capítulo seguinte, mediante uma visão rāpida de alguns aspectos da politica agrícola e das ca racteristicas mais salientes do setor agrícola nesse país. 


\section{CAPÍTULO II - A AGRICULTURA VENEZUELANA}

\section{1 - Petröleo, felicidade ou Desgraga?}

Se do contexto latinoamericano passamos ao caso específico venezuelano, poderia-se assinalar, em grandes traços que, se no resto dos países da região, o modelo de mudança so cial fundamentada na modernização da agricultura chegou a pro duzir grandes desequilibrios no setor rural, na venezuela, a situação foi mais crîtica, porque o paîs deixou de ser agrīco la para tornar-se produtor de petróleo.

A Venezuela rural não escapou à onda ideológica modernizante que se abateu sobre a América Latina, impelida por um centro poderoso de desenvolvimento atravēs de seus inúme ros tentäculos institucionalizados. Esta situação tornou-se ma is complexa com o aparecimento de um aliado igualmente pode roso, o petrōleo, que, alēm de acelerar o processo de descom- 
posição do setor agrỉcola, acabou de enterrar as últimas esperanças das massas camponesas de alcançar uma existencia mais digna em seu próprio meio, expulsando-as para os centros que a "cultura do petróleo" converteu em pequenos oásis de progres so material, contrastando com o resto do paiss, abandonado e mi serāvel.

A exploração do petróleo por parte das companhias pe trolíferas não só levou a agricultura a um crescimento depen dente, como também, além disso, provocou nos círculos governa mentais uma subestimação da mesma e dos problemas sociais con sequentes, a tal ponto que, segundo alguns autores, atē não muito tempo, existia no pais um total abandono para com o pro blema agrário e um enorme exagero com relação aos problemas provenientes da existência de uma agricultura tradicional.

Com relação aos desequilíbrios que a exploração petroliffera ocasionou em todo o àmbito nacional e, em especial, o poderoso influxo exercido pelo petróleo sobre o setor agrícola, achamos oportuno citar LOSADA (1976: 35-46) quando diz "o peso excessivo do petróleo no Produto Territorial Bruto (PTB), sua assombrosa significação nas exportações e sua força como meio de pagar as importações, sua participação ilimitada nas rendas fiscais e nas possibilidades de gasto público, seu carāter de setor fundamental da economia, sua intervenção em todos os niveis da vida social e politica da Venezuela e, sobre tudo, a natureza estrangeira e as funções exteriores de sua exploração, tudo isto pesou e pesa com uma força extraor- 
dināria sobre a mentalidade e as atitudes sociais do país". Quanto à repercussão do petrōleo na agricultura, acrescenta o autor que "todos os sintomas da politica agrícola da Venezuela do momento, com sua particular incidéncia na modernização tecnológica desvinculada da reorganização social, tinha de conduzir, à luz das anālises precedentes, a maiores desigualdades sociais, às mais profundas assimetrias na dis tribuição de renda, ao aumento de desemprego, ao crescimento do éxodo rural, a superiores nīveis de desnutrição e pobreza; tudo isto conexo com a consolidação de uma nova oligarquia agrícola capitalista aliada a exploração transnacional do país". Indubitavelmente, o aparecimento do petrōleo em 1920 e sua consolidação como setor dominante e como elemento de maior influência política no mundo, a partir de 1945, implica toda uma transformação na vida politica, econōmica e social do país, cujos efeitos ainda pesam e distinguem a Venezuela de ho je. Paralelo ao comércio petrolífero, ocorre um aumento da produtividade do trabalho, a evolução das aplicações cientifi cas e técnicas, processos de decomposição e diferenciação das classes, gestação e instauração do capitalismo agrícola, etc. Tanto isto é verdade que, quando se fala das causas principais do fracasso da agricultura venezuelana, além de as sinalar a extrapolação de culturas e de métodos de produção e ficazes nos locais de clima temperado que fracassam ou de ba xa rentabilidade no meio tropical, impedindo o desenvolvimento de uma verdadeira agricultura tropical, também faz-se refe 
rência ao enorme fluxo de dinheiro que o paîs percebe, sem 0 que seria requerido muito esforço, proveniente da extração e exportação de um recurso natural não renovável como ē o petrō 1eo.

Durante o periodo presidencial findo em março de 1979, dois agrupamentos importantes ligados e controlados pe10 mesmo partido politico do governo, emitiram declarações que colocam em tela de julgamento a polittica agrícola implementada até esse momento pelo Estado venezuelano.

Como em 1975, a Comissão designada pelo então Presi dente da República, Carlos Andrés Pérez, a fim de avaliar e re-estruturar os organismos da Reforma Agrāria, foi unānime em afirmar que a estratégia planejada pelo atual governo para o desenvolvimento agrīcola, por meio da modificação nas relações de troca entre a agricultura e a indústria, o aumento do desem prego e o freio ao custo de vida, não tinham dado os resultados desejados, principalmente no que tange ao setor camponès.

Desta forma, pelo julgamento da Comissão, a crise da agricultura, no que diz respeito aos pequenos e médios agricultores, aos beneficiārios da Reforma Agrāria e aos traba Thadores avulsos do campo (tarefeiros), não tinha sido supera da e, se continuasse em vigor a atual estratégia,jamais seria superada; para os setores majoritārios do campo, a migração o desemprego e o aumento do custo de vida continuavam vigentes.

A Federação Camponesa da Venezuela (FCV), por seu la do, reunida em Conselho Diretivo Nacional, nesse mesmo ano, e 
acoihendo as recomendações da Comissão, referida anteriormente, admitia a difícil situação, que, nessa ocasião, preocupava seus dirigentes, que era o auge alcançado por um desenvolvimen to agrícola com características de empresas agrícolas capitalistas e o que era mais grave ainda, financiadas pelo próprio Estado.

$\mathrm{Na}$ verdade, este processo não è recente, posto que o desenvolvimento capitalista tem sido um elemento sempre pre sente, durante as $\bar{u} l t i m a s$ décadas, no setor agrícola venezuelano e tal processo segundo MARTEL (1976:87) "estā inserido dentro da dināmica geral da política de substituição de impor tações, tem sido promovido fundamentalmente por setores indus triais que utilizam insumos de origem agricola e que procuram por isso garantir seu abastecimento".

Para uma melhor compreensão da situação, acha-se con veniente assinalar que na Venezuela pré-petroleira, a ativida de agrícola caracterizou-se por sua marcada orientação para o mercado externo, começando com o ciclo do cacau, (segunda metade do século XVI até o século XVIII) depois, cedendo lugar ao café (quase todo o século XIX até a primeira metade do século $X X)$. Esta situação monoexportadora foi alterada profundamente com o advento de petróleo e assim também toda a agriculturà.

A agonia da agricultura venezuelana começou com a violenta queda dos preços dos produtos agrícolas durante os a nos de 1929 e 1935, anos criticos que estremeceram o mundo e- 
conōmico e que segundo alguns observadores, chegou a alcançar cerca de $70 \%$ na queda dos preços; e depois, com o auge alcançado pelo negōcio petrolífero, cuja importāncia e magnitude fez com que toda a atividade económica nacional girasse em seu redor; situação que deu lugar a um violento aumento na ca pacidade aquisitiva da população, portanto, do mercado interno, condição que bem poderia ter sìdo aproveitada na dinamiza ção do desenvolvimento agrīcola.

Não obstante, diante de uma agricultura em declīnio e divisas petroleiras em ascenção, os diferentes governos escolheram o caminho mais fácil; ante as exigēncias de um merca do interno cada vez maior, optaram pela importação maciça de produtos agrícolas, beneficiando com seu agir as firmas comer ciais importadoras, intimamente relacionadas com os grupos de poder estabelecidos em nível mundial do sistema capitalista.

Desta forma, a Venezuela começou a alimentar-se de fontes externas, demonstrando o artificial de seu setor agrícola. A medida que se incrementava a demanda de produtos agrícolas, como consequéncia do poder de compra, graças ao recebido com as vendas de petróleo, pelo crescimento da população e pela procura industrial, tornou-se necessário recorrer cada vez mais às importações, a tal ponto que estas passaram de 417 milhões de bolívares em 1966 a 2.021 milhoes em 1973 e para 1975 , o valor das importações superou os 3.500 milhões de bolívares.

Para HERNANDEZ (1977:4) "quando o avanço da politi- 
ca de substituição de importações torna necessārio que uma par te da matéria prima para a agroindústria seja produzida no pais, jā os setores agroindustriais tem consolidado seu dominio sobre o mercado interno. Isto permite-lhes impor aos pro dutores agrícolas condições equivalentes às que gozavam com as importações, estabelecendo preços de monopólio artificialmente baixos para as matérias primas de origem agrícola".

Segundo MARTEL (1976:90-91), existem trēs traços de desenvolvimento capitalista no campo venezuelano:

a - "sua subordinação aos interesses agroindustriais, os quais mediante o controle que detem da oferta agricola", impõem as condições assinaladas anteriormente por Hernández, si tuação que se torna difícil devido às próprias condições que estabelece o desenvolvimento capitalista: tecnifica ção acelerada e especialização do trabalho.

b - a expansão da produção agrīcola "empresarial", representada por um conjunto de produtores não camponeses, surgi dos ao calor do processo de substituição de importações

e que participam plenamente das relações capitalistas.

Isto deu lugar, na opinião de Hernāndez, a uma agri cultura de aventura, extensiva e exaustiva em seus métodos de operação ou exploração, carente de inversão fixa a largo prazo e altamente dependente da política oficial, assim como dos setores agroindustriais.

c - O rápido impulso das massas camponesas para converter-se em mão-de-obra assalariada ou em marginais do campo. A 
utilização de uma tecnologia deslocadora de mão-de-obra, e a baixa propensão às inversões fixas que caracterizam a nossa agricultura de aventura, fez com que a quantidade de trabalhadores requeridos pelas explorações capitalistas seja também reduzida. Por isso, os camponeses que permanecem no campo, arruinados pelo capitalismo, devem conformar-se em ser diaristas ocasionais, subempregados, marginais do campo.

ou, em todo caso, os camponeses vēem-se compelidos, contra seus próprios interesses, a adquirir insumos, maquinarias e artigos manufaturados de origem industrial. A assis tência técnica e os variados tipos de créditos, são instrumen tos adequados a este fim, mas ainda quando se coloca nas mãos de profissionais formados com um critério não menos mágico qual seja, de que a solução dos problemas do campo esteja na mecanização e na utilização de quanta tecnologia nova for inventada.

2 - Uima Política Agrícola Comprometida

Julga-se ser conveniente dar início a este tema, co locando de imediato duas considerações que, além de serem importantes para compreensão do mesmo, provēm do Diretor Geral de Planificação do Ministério da Agricultura, que, para a épo ca da concretização do V Plano de Nação, estava a cargo do ecomista Douglas Jatem, e tais considerações segundo JATEM 
(1976:19), são as seguintes:

a - "0 V Plano da Nação, tem como objetivo básico delinear a politica do Estado; suas metas serviram de marco para acelerar a mudança social, conseguir uma produção com ren dimentos adequados às necessidades modernas e propiciar a utilização dos insumos tecnológicos (...).

b - Um aspecto importante em matēria de politica agrícola, é conseguir a participação do setor privado no processo de desenvolvimento económico e social planejado, mediante es tímulos económicos, incentivos fiscais ou qualquer outro instrumento que seja considerado conveniente e necessá rio a tal fim.

Sem Comentārios.

o V Plano da Nação, como ficou dito na parte introdutōria do trabalho, é o instrumento que contēm os traços essenciais do desenvolvimento económico e social da República du rante o periodo 1976 a 1980 , do qual foram selecionados alguns aspectos que se julgam fundamentais para a compreensão de no $\underline{s}$ sa problemática.

Em relação ao setor agrīcola, o mencionado instru mento, V PLANo (1976:79), em seus traços gerais, acimite que "o desenvolvimento integral do país atribui ao Setor Agríco la, a obrigação, entre outrás, de:

a - satisfazer importantes solicitaçōes em matéria de produção para atender, adequadamente, à demanda do consumo di 
reto por parte da população;

b - de matērias-primas para a indūstria;

c - a incorporação do camponēs a uma participação ativa e di reta no processo de desenvolvimento económico e social do pais".

Entre as prioridades, no campo social, V PLANO (1976:

83), a ação do Estado será orientada a:

a - "estruturar programas de capacitação integral para tarefas definidas que constituam um meio eficaz para prepa rar mão-de-obra especializada nos trabalhos agrícolas:

b - criação de centros rurais de instrução e educação integral para estimular a capacidade criativa do indivíduo e assimilação de técnicas modernas.

Entre as estratégias a seguir, em relação a Reforma Agrāria, V PLANO (1976:86):

a - "estimular-se-ā a formação de organizações rurais com uma estrutura geral e eficiente, de acordo com a qual pos sa ser incorporada definitivamente a Reforma Agrāria, ao processo de desenvolvimento mediante a criação de grandes complexos produtivos, agropecuários, agroindustriais e de serviços que se integram como empresas mistas. Esta organização empresarial será constituída com a participa ção de organizações camponesas e do Estado, mediante fōr mulas de integração produtiva que permitam adaptar tecno Togias modernas; ( . . f) facilidades para a mecanização, aquisição de fertilizantes $(\ldots) "$. . 
Em termos de tecnologia agricola:

a - "foram dados passos programados para que a investigação tecnológica, principalmente a que o Estado realiza, produza maiores e melhores resultados a médio e a longo prạ zo, prestando maior atenção à capacitação do pessoal.

b - orientaram-se os trabalhos de investigação até a geração e difusão de conhecimentos para que os produtores apli quem,tanto do ponto de vista económico como do técnico, práticas produtivas que permitam, por meio de combinações tecnológicas, obter maiores rendimentos por unidade de superfície e não signifiquem desfalque de mão-de-obra $(\ldots)$.

c - propiciar-se-á a transformação tecnológica que incorpore continua e oportunamente novas tecnologias, tendentes $\bar{a}$ modificação da agricultura (...)".

Além disso, o V PLANO (1976:92) determina, "Criar se-ā O Instituto Nacional de Capacitação Rural, que terá como característica a execução da politica de capacitação cujo efeito deverá centralizar, em harmonia com outros organismos do Estado e especialmente com o Ministério da Educação, a ação oficial em tudo que diz respeito a capacitação do campo nẽs para o uso de tecnologias agrícolas, pecuārias e florestais".

Em relação ao setor educacional, tal instrumento o $V$ PLANo, (1976 : 209-210) determina que "o sistema educativo o- 
rientar-seá de forma que os venezuelanos possam alcançar, através da potencialidade criadora da sociedade, a possibilida de de atuar eficazmente sobre seu prōprio destino. Para isto procederā, entre outros, a:

a - fomentar a interação entre a investigação cientîfica e tecnológica do meio académico e os setores da produção pū blica e privada, pretendendo que estes setores apoiem progressivamente sua atividade económica nos recursos na cionais que existam no campo da investigação;

b - cumprir com os compromissos adquiridos e desenvolver novos projetos de cooperação nas āreas da educação, cien cia e cultura a nivel dos organismos regionais e interna cionais, tais como a UNESCO e OEA;

c - estabelecer convēnio de cooperação bilateral e multina cionais para geração de conhecimentos, criação e transfe réncia de tecnologia e para o intercámbio cultural".

Um indicador de tal situação, é o convēnio de colabo ração tecnolōgica entre o Ministério da Agricultura de nosso paîs e a Universidade de Purdue, nos Estados Unidos, especializada em investigações tecnolögicas no campo da agricultura. Em relação ao setor de ciéncia e tecnologia, o V PLA NO (1976:240-242), apesar de se reconhecer que se tenha socor rido de utilização de tecnologia externa de característica inadequadas as nossas necessidades, entre as estratégias vamos encontrar: 
a - instrumentação de programas de capacitação de recursos humanos com o objetivo de melhorar as condições de uso, negociação e transferência de tecnologias assimilāveis dos países desenvolvidos;

b - diversificação racional da fonte externa de tecnologia. Quer-se parecer que, a inda que muito resumidamente, os aspectos assinalados, contidos no V PLANO e, apesar da retórica oficial que, às vezes, chega a criar situações contraditórias, refletindo uma falta de seriedade, os aspectos assi nalados, permitem formar uma idéia bastante clara dos verda deiros objetivos do V PLANO; se tal documento procura mudanças sociais, estas não aparecem de um dia para o outro como deixa ver claramente a retórica política, sem que antes ocorram mudanças profundas nas relações sociais.

Se, historicamente, as transformações bāsicas partem do regime económico que repercutem depois em toda a estrutura, existe uma grande diferença entre estes tipos de transformações e as ocasionadas quando intervēm no processo, uma ação cons ciente e deliberada no sentido de acelerar o ritmo da mudança do regime económico. Portanto, as contradições e assimetrias são mais agudas e profundas entre as diferentes partes da estrutura; segundo COSTA-PINTO (1967:109), "esse é o caso dos paises ou das sociedades de enconomia menos desenvolvidas, em que a promoção da transformação faz-se intencional, racional, e provocada, como meio de suprir pela planificação de desen volvimento económico, os indices de atraso que se procura su- 
perar a curto prazo".

Sob esta perspectiva, os programas do Estado relacio nados com a saūde e segurança social, educação, etc., tem como fim a "reprodução física do trabalhador". O cuidado da saū de mediante os serviços médicos, por exemplo, corresponde à necessidade de contar com um pessoal relativamente são, procu rando a manutenção de altos nĩveis de produção em benefício da empresa; enquanto com relação a educação, os programas são en caminhados para providenciar um produto instrumental a o a luno a fim de obter aumentos na produção material de bens e serviços.

os programas propostos nas àreas de pesquisas cientí ficas e tecnolōgicas não estão orientados a resolver os problemas sociais do meio rural venezuelano; sua excessiva orien tação na produtividade, impede desenvolver estudos sobre as consequéncias sociais do desenvolvimento tecnolögico, ignoran do o impacto da agricultura "moderna" sobre a qualidade de vi da .

Citado por HERNANDEZ (1976:16-19), a Direção de In vestigações do Ministērio da Agricultura, anexa ao Fundo Nacio nal de Investigaçōes Agropecuārias, assinala o seguinte:

a - "a investigação ag̣ícola está orientada para o desenvoI vimento agrīcola especialmente, isto é, à procura de so1 uções dos problemas referentes à produtividade e aos mé todos que permitam tornar realidade o potencial agrope cuārio do paîs. 
b - a investigação busca o uso de métodos e sistemas experimentais modernos, destinados a conseguir maiores rendi mentos na produção agropecuāria, mediante a obtenção de vegetais e animais de maior produtividade.

c - os pesquisadores, em sua grande maioria agrónomos, veterinārios ou zootecnistas, realizam, tém realizado ou rea lizarão cursos de pos-graduação em universidades estrangeiras de paises desenvolvidos, desvinculando-se, progres sivamente, o pesquisador da realidade da Venezuela, contribuindo para reforçar os quadros de dependēncia tecno1ógica ao especializar-se em āreas, sem monosprezar a importāncia que estas tenham, não representam em muitos ca sos as necessidades mais urgentes do setor; outras vezes, por serem tão sofisticadas e produto de paises alta mente desenvolvidos, não têm aplicação, nem muito menos de imediato, em nosso setor.

d - a nível da Direção de Investigações do Ministērio da Agricultura, as àreas de investigação estão agrupadas em grandes programas que visam à utilização no setor vege tal, de sementes melhoradas em culturas, tais como, gergelin, cana-de-açūcar, milho, leguminosas, controle de pragas e vacinas para o setor anima?".

Há certa ènfase, pois por parte do V Plano de desenvolver pacotes tecnológicos que ao serem transferidos ao setor agrícola permitem aumentar a produção e os niveis de produtividade, isto significa a necessidade de preparar mão-de-o 
bra qualificada e barata que sirva de instrumento para sua concretização; por isso hā a formação e adestramento de técnicos que possam atender às solicitações de trabalho por parte de grandes empresas nacionais ou multinacionais.

Estando a investigação, a ciēncia e a tecnologia a serviço da reprodução e manutenção do sistema de domỉnio, cabe ao Estado como diz CHOSSUDOVSKY (1977:18), "(...) prover ao setor produtivo a infraestrutura social e as 'inversões so ciais' nas quais se apoia o processo capitalista".

Segundo os textos citados do V PLANO, o Estado pre tende fazer da agricultura uma atividade económica suficiente mente remuneradora a fim de incentivar a produção de produtos básicos tradicionalmente deficitārios para o consumo nacional como também os que constituem matéria prima para a agroindústria ; como também lograr uma exportação do excedentes naqueles produtos os quais o pais possui vantagens comparativas e reduzir o nivel de desemprego e a migração rural-urbana.

Estes objetivos, na realidade, estão dirigidos à con figuração de um contexto muito mais amplo e geral, como atingir a uma maior racionalização das relações capitalistas de produção existentes, o que significa uma mudança no papel que desempenham os centros externos de poder e não uma ruptura com eles; como pretendem crer alguns setores do país que veem na nova politica agrīcola uma mudança nas formas de produção,que levaria a romper de uma vez com a situação de dependéncia. 
Diante de toda esta situação, o camponēs se mantēm como um mero expectador do processo de modernização agrỉcola; assim, segundo as afirmações do documento CONICIT-CENDES

(1976:24-26), "(..) o camponēs fica inserido no mecanismo de produção e distribuição de produtos agrícolas, de mercado de trabalho e de tomada de decisões sobre o qual não tem controle algum".

Este "status" se reforça nas características prōprias do camponés como grupo social, o qual vem diminuindo pela des nutrição, seu vigor físico e psĩquico; sua capacidade de luta por seus direitos tem sido rebaixada por um jogo politico, que se aproveita do analfabetismo e incultura que os setores dominantes não têm resolvido, ao que parece, para contar com um terreno fértị ou fácil de ser manejado.

Continua dizendo o documento que esta é uma classe de sapropriada de seus meios de produção, que tem perdido parte de sua capacidade de trabalho e gestão como consequéncia do an terior e da imposição de té̄nicas que não domina. Finalmen te, é uma classe social em acelerado processo de empobrecimen to.

Nos momentos atuais, o pais se encontra sem uma produção agrīcola que atenda, pelo menos, a seu abastecimento, tendo que recorrer, uma vez mais, as importações maciças de produtos básicos na alimentação de sua população. Em abril de 1977 , o governo decretou a livre importação de alimentos, estabelecendo-se uma ponte aérea para trazer-se ao país leite, 
café, queijo, pescado, manteiga, carne, feijão, ovos, bananas, frango, vinagre, atum, sardinha, batata, milho, sal, carne de porco, etc.

A esse respeito diz GONZALEZ (1978:4) "este fato determina conforme pensamos, pelo menos duas consequēncias importantes:

a - a necessidade de consumir grande quantidade de divisas em produtos alimenticios, muito caros e escassos no mercado internacional, o que de certa forma equivale a vender os produtos de exportação a baixo preço;

b - a vulnerabilidade do país em algo tão vital como é a ali mentação, o que é muito grave dentro do ponto de vista da independéncia e soberania nacional".

0 documento CONICIT-CENDES (1976:16), por outra parte, comenta que "desde o ponto de vista da soberania nacional, se cria uma situação de dependência de tal grau, que comprome te seriamente nossa condição de pais independente e nos coloca diante do mundo em um plano de incapacidade e abandono das mais elementares obrigações de um paîs, como é alimentar sua população. De outro lado, não se aceita o esforço que o paîs faz para dotar suas forças armadas de modernos armamentos, en quanto se tem uma brecha estratégica, como é a provisão de alimentos, praticamente esquecida.

Esta situação é por demais crîtica e sumamente delicada; O fato de que o pais tenha que importar mais de $50 \%$ do consumo de calorias e proteina, reflete a vulnerabilidade de 
sua politica internacional se recordamos que a politica esboçada em 1975 pelo Presidente e Secretārio da Defesa dos Estados Unidos expressava, entre outras coisas, que aqueles pa $\overline{-}$ ses que tivessem fome, poderiam comprar os alimentos sempre e quando sua politica internacional não fosse contra os interes ses norteamericanos.

3 - 0 campo Sob o Signo da Democracia

Nos ūitimos vinte anos, no "paraíso democrātico" da América Latina, o meio rural tem sido palco de grandes transformações as quais têm produzido um impacto profundo e decis i vo nas relações entre o homem e a terra.

A maioria dos que, na Venezuela, têm como ārea de es tudo e de trabalho o setor agrícola, estão de acordo em assinalar como característica principal do meio rural atual, a di namização do moderno desenvolvimento capitalista na agricultu ra, constituindo-se um elemento dominante de toda a atividade agropecuāria, arrastando e redefinindo no seu bojo, qualquer outro tipo de relação mais atrasada; o desenvolvimento capitalista do campo, como já comentado páginas atrās, marca seu início no desenvolvimento empresarial modernizante, produzido a partir da politica de substituição de importações, implemen mentada de forma decisiva e concreta a partir de 1958.

A partir dessa data, a agroindústria começa a ditar as linhas que devem ser cumpridas no restante do setor, funda 
mentando-se no completo dominio que exerce sobre o mesmo,que, segundo HERNANDEZ (1977:3-4), se produz em dois nîveis:

a - "em nivel de tipo tecnológico. A agroindústria é capaz de impor, por meio do controle que exerce sobre o financiamento e por meio do controle que de uma maneira ou de outra exerce sobre a pesquisa e a extensão agrícola, um pacote tecnológico que até certo limite determina as decisões técnicas fundamentais que se produzem nas proprie dades rurais.

b - em nīvel económico. Os setores agroindustriais tem a pos sibilidade, com o domínio que têm sobre o mercado, de es tabelecer preços de monopólio, tanto para os insumos e maquinaria que sejam necessārios para a produção agrícola como para a matēria-prima de origem agrícola, impondo um intercāmbio desigual entre a agricultura e a indusstria".

Em torno desta situação de completo domĩnio por parte da agroindústria no que se refere à atividade agrícola,pro cessa-se uma estratificação social a qual, segundo a opinião de HERNANDEZ (1977:7-8) "se divide em trés grandes setores: setor dominante, setor intermediārio e setor dominado.

A - Setor dominante:

Com hegemonia dos setores agroindustriais, agrocomer ciais e financeiros que processam matēria-prima de origem agrícola ou que abastecem os produtores de insumos e maquina - 
rias. Ao seu redor articula-se um conjunto de setores, que participa de seu domínio sobre o setor agrícola:

a - os grandes produtores agrícolas enriquecidos a partir do aproveitamento privilegiado das politicas fomentistas e que tēm logrado, por este meio, capitalizar e associar se à agroindūstria.

b - os grandes criadores de gado que dividem com os setores agroindustriais e com os grandes empresārios do campo, o dominio sobre a agricultura.

c - as "roscas" ou intermediārios, que controlam o mercado de produtos de consumo direto e os setores que se enrique cem e capitalizam pela via camponesa (aparecimento de uma burguesia agrāria, vinculada à produção de hortaliças e de produtos de consumo direto), isto é, uma nova bur guesia de setores que ainda sendo aparentemente pobres, têm uma ampla possibilidade de capitalizar dentro do desenvolvimento capitalista atual e associar-se com as "ros cas".

d - setor latifundista, reivindicado a partir da nova dinámi ca que nasceu em redor do problema da terra; tende a as sociar-se dentro do bloco dominante e a constituir-se em um elemento dentro dele.

B - Setor intermediārio:

Atuam na direção dos produtores médios e dos campone ses. Responde a interesses pröprios, relacionados com sua po 
sição de poder e, por outro lado, vêem-se obrigados a responder aos interesses dos setores sociais que representam.

a - médios produtores, vinculados à produção para a agroin dústria e que apresentam algumas possibilidades de capitalizar.

b - pequenos produtores, vinculados à produção para o consumo direto e que não estão claramente definidos entre aqueles que têm uma possibilidade real de capitalizar e aqueles que se vão proletarizando.

c - pequenos e médios comerciantes, transportadores; os setores pequenos e médios que fornecem serviços para agricultura ; integrados à dinâmica da produção agrî́cola.

C - Setor dominado:

Constituīdo por uma boa parte de médios e pequenos produtores integrados à produção para a agroindūstria e pelo que poderíamos chamar o setor camponés.

a - setor camponès: segundo pensamos, não é em si uma classe e estā composto por setores sociais com dinämicas eco nömicas bastante distintas:

- camponēs que tenha avançado dentro do processo de pro letarização e que tenha sido convertido em diarista marginal, abandonanó progressivamente a economia de subsistēncia.

- trabalhadores permanentes ou semipermanentes que tenham uma maior afirmação de sua condição de proletários. 
- pequenos produtores, camponeses que se encontram fora do contexto de Reforma Agrāria.

- "conuqueros" - camponēs cujo sistema de produção é o "conuco", ver definição na pägina 85 -, vinculados à economia de subsistēncia".

Para complementar esta visão geral do campo venezuelano, temos considerado importante a inclusão de algumas tabe las elaboradas por diversos autores e que para os objetivos deste trabalho, constituem um recurso metodológico bastante $\bar{u}$ til.

Devemos esclarecer, com relação as tabelas que apresentamos e que são estas as que mais se ajustam à problemática do trabalho, que são insuficientes devido a pouca importān cia que se tem dado a este aspecto de setor agricola por parte dos organismos estatais, talvez, como é natural, para não desmascarar os continuos fracassos das politicas agricolas im plementadas pelo Estado. Um exemplo disto, constituem os Cen sos Agropecuārios, os quais não se realizam desde 1971 e os $\underline{A}$ nuārios Estatīsticos Agropecuārios desde 1974.

O Informe Económico do Banco Central da Venezuela de 1976, é o documento com dados estatísticos mais recentes de que dispomos e do qual extraỉmos as Tabelas I, II e II (Apēn dice), sobre produção do setor agrīcola, ārea colhida e produ ção bruta até 1976 e estão colocadas em forma de àpēndices.

o problema da posse da terra continua sendo um dos mais graves do setor agricola. Depois de 18 anos de iniciado 
o processo da Reforma Agräria, os altos indices de concentração da terra não tem variado consideravelmente. Como se observa na Tabela 1, 4.905 explorações maiores de 1.000 hecta res, que representam $1,7 \%$ do total das explorações agrícolas, concentram-se em $67 \%$ da terra disponivel; enquanto que no ou tro extremo, as explorações menores de 10 hectares que são $60,3 \%$, só possuem $2,2 \%$ da superfície agrícola.

TABELA 1 - Distribuição da posse da terra. Venezuela, 1971

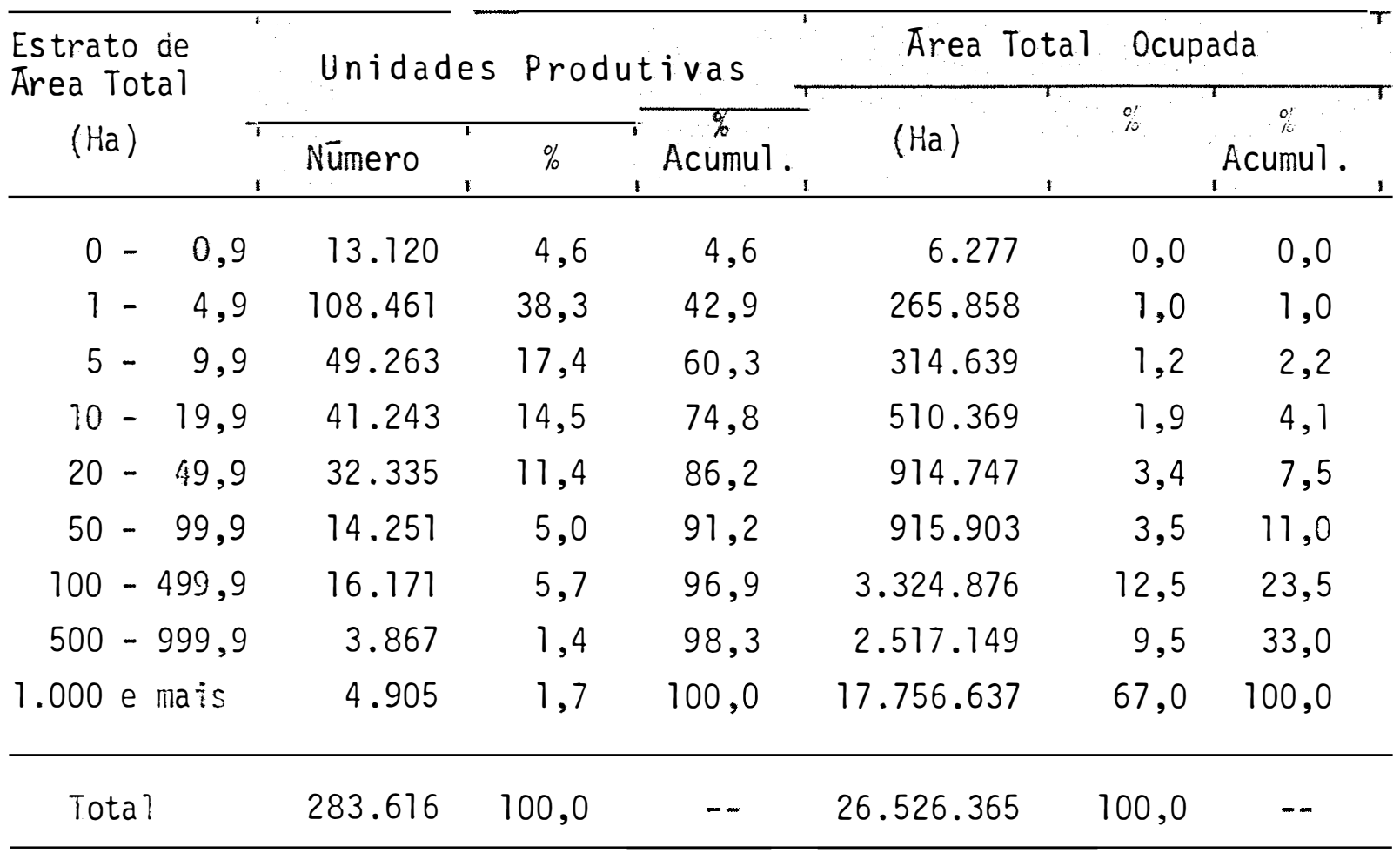

Fonte: Comissão de Avaliação e Reestruturação dos Organismos de Reforma Agrāria. Censo Agropecuārio de 1971. 
A evolução de 1959 a 1968, pode-se observar na Tabe$1 a 2$, onde se constata que à produção experimenta um significativo programa ao passar de 17.424 toneladas métricas em 1959 para 359.927 em 1968. Em termos de porcentagem a produção na cional de fertilizantes tem aumentado em $1.966 \%$ no decēnio considerado.

Por outro lado, a importação decaiu de 56.048 tonela das métricas para 47.427 ; de modo que, se a importação diminuiu em $15 \%$, sugere um crescimento importante do consumo de nu trientes por parte da agricultura e a insuficiēncia da produção nacional para satisfazer a procura interna.

0 uso de tais produtos tem alcançado altos valores no de correr dos ūltimos anos. A produção nacional como o demonstra a Tabela 3, ainda que da mesma participem insumos importa dos, tem passado de 1.280 toneladas métricas em 1959 a 11.420 em 1973, o que significa um indice de incremento de $792 \%$ e um indice anual de $53 \%$.

A julgar pelo crescimento anual na elaboração dos mes mos no Ministério da Agricultura (MAC), a aplicação deste re curso científico experimentou incrementos nada desprezíveis $\underline{a}$ té 1966 como indica a Tabela 4 ; sem dūvida, a partir de 1967, coincide a transferēncia parcial à fabricação particular e o decréscimo vertical da produção o qual contribui para privile giar mais ainda a situação empresarial e enfraquecer a situa ção camponesa, pois esse deslocamento tornou mais difícil o acesso camponés a tais produtos. 
TABELA 2 - Produção e importação de Fertilizantes (Ton.) Venezuela, 1959-1968 (1959=100)

\begin{tabular}{|c|c|c|c|c|c|c|}
\hline \multirow{2}{*}{ Anos } & \multicolumn{2}{|c|}{ Produçã̃o (a) } & \multicolumn{2}{|c|}{ Importação (b) } & \multicolumn{2}{|c|}{ Soma Total } \\
\hline & Tonelada & Indice & Tonelada & Indice & Tone lada & Indice \\
\hline 1959 & 17.424 & 100 & 56.048 & 100 & 73.472 & 100 \\
\hline 1960 & 22.384 & -128 & 61.379 & 110 & 83.763 & 114 \\
\hline 1961 & 45.861 & 263 & 62.604 & 112 & 108.465 & 148 \\
\hline 1962 & 57.866 & 332 & 75.705 & 135 & 133.569 & 182 \\
\hline 1963 & 68.260 & 392 & 60.913 & 109 & 129.173 & 176 \\
\hline 1964 & 113.244 & 650 & 39.566 & 71 & 152.810 & 208 \\
\hline 1965 & 240.236 & 1.179 & 45.546 & 81 & 285.782 & 389 \\
\hline 1966 & 273.927 & 1.572 & 31.248 & 56 & 305.175 & 415 \\
\hline 1967 & 276.838 & 1.589 & 45.427 & 85 & 324.265 & 441 \\
\hline 1968 & 359.927 & 2.066 & -- & -- & -- & 490 \\
\hline
\end{tabular}

(a) Inclui produtos primários, intermediārios e mistura de fertilizantes .

(b) Adubos nitrogenados e produtos fertilizantes nitrogenados não especificados .

Fonte: República da Venezuela (MAC). Anuārios Estatísticos Agropecuāa rios de 1967 e 1968. 
TABELA 3 - Produção e importação de inseticidas (ton). venezuela, 1959-1973 (1959=100)

\begin{tabular}{rrrrr}
\hline Anos & Produção & Indices & Importação ${ }^{+}$, Indices \\
\hline 1959 & 1.280 & 100 & 10.350 & 100 \\
1960 & 927 & 72 & 11.051 & 107 \\
1961 & 2.132 & 167 & 9.665 & 93 \\
1962 & 4.015 & 314 & 7.038 & 68 \\
1963 & 3.551 & 277 & 2.765 & 27 \\
1964 & 5.754 & 450 & 3.733 & 36 \\
1965 & 8.270 & 646 & 5.018 & 48 \\
1966 & 6.614 & 517 & 3.043 & 29 \\
1967 & 8.529 & 666 & 3.737 & 36 \\
1968 & 8.930 & 698 & 3.364 & 33 \\
1969 & 9.113 & 712 & 3.310 & 32 \\
1970 & 5.891 & 460 & 3.506 & 34 \\
1971 & 9.580 & 748 & 3.168 & 31 \\
1972 & 10.639 & 831 & 2.644 & 26 \\
1973 & 11.420 & 892 & -- & - \\
\hline
\end{tabular}

(+) Refere-se tambēm a: desinfetantes de creolina, creo sol e pinho, fungicidas, herbicidas, raticidas, similares e não especificados

Fonte: MAC - Anuārio Estatīstico Agropecuārio. 1972/73. 
TABELA 4 - Produtos biológicos elaborados pelo Ministério da Agricultura. Venezuela. 1959-1973

\begin{tabular}{lc}
\hline Anos & \multicolumn{1}{c}{ Doses } \\
\hline 1959 & 3.051 .953 \\
1960 & 19.417 .080 \\
1961 & 25.598 .670 \\
1962 & 36.972 .212 \\
1963 & 49.469 .066 \\
1964 & 52.135 .809 \\
1965 & 52.776 .330 \\
1966 & 31.152 .370 \\
$1967+$ & 10.648 .920 \\
1968 & 7.501 .045 \\
1969 & 8.632 .288 \\
1970 & 6.361 .412 \\
1971 & 8.879 .212 \\
1972 & 8.571 .960 \\
1973 & 6.512 .988 \\
\hline
\end{tabular}

(+) A partir de 1967 a fabricação de algumas vacinas passou para a indústria privada.

Fonte: MAC - Anuārio Agropecuārio 1962 a 1973. 
A Tabela 5 mostra o curso da produção venezuelana em matéria de alimentos concentrados para bovinos, suinos e aves, em toneladas métricas e entre os anos 1950 e 1973, anos em que se têm agrupados em quatro quatriēnios, um triênio e um quinquênio final. No gado bovino pode-se observar uma evolução que vai de 55.931,9 toneladas em 1950/53 a 248.404 em 1962/ 65 a 190.329 em $1966 / 68$ e a 352.262 em 1969/73.

Se tomarmos por base o termo médio anual, em cada um dos grupos de anos, o processo assinala um indice de 100 entre 1950/53, contrapondo-se a um de 340 entre $1966 / 68$ e outro de 630 entre 1968/73. A produção de alimentos concentrados para suínos é a de maior significado, progredindo de um ponto médio anual de 266.3 toneladas entre 1950/53 a outro de 212.935 entre $1969 / 73$, pelo qual o indice passa de 100 para o primeiro período a 99.951 no ūt timo período mencionado.

Finalmente, a produção de alimentos concentrados para aves também experimentou uma expansão digna de ser levada em conta. De um ponto médio anual para o primeiro quatriênio

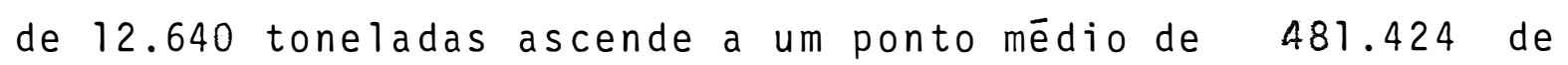
1968/73, com um indice de promédio anual que se eleva de 100 para o quatriênio inicial a 4.761 no quinquēnio final. Não ca be dūvida ante tais cifras, que ocorreu um inegāvel progresso na matēria, não obstante haver, como em todas outras evoluções mudanças radicalmente reduzidas a um setor muito limitado de explorações. 


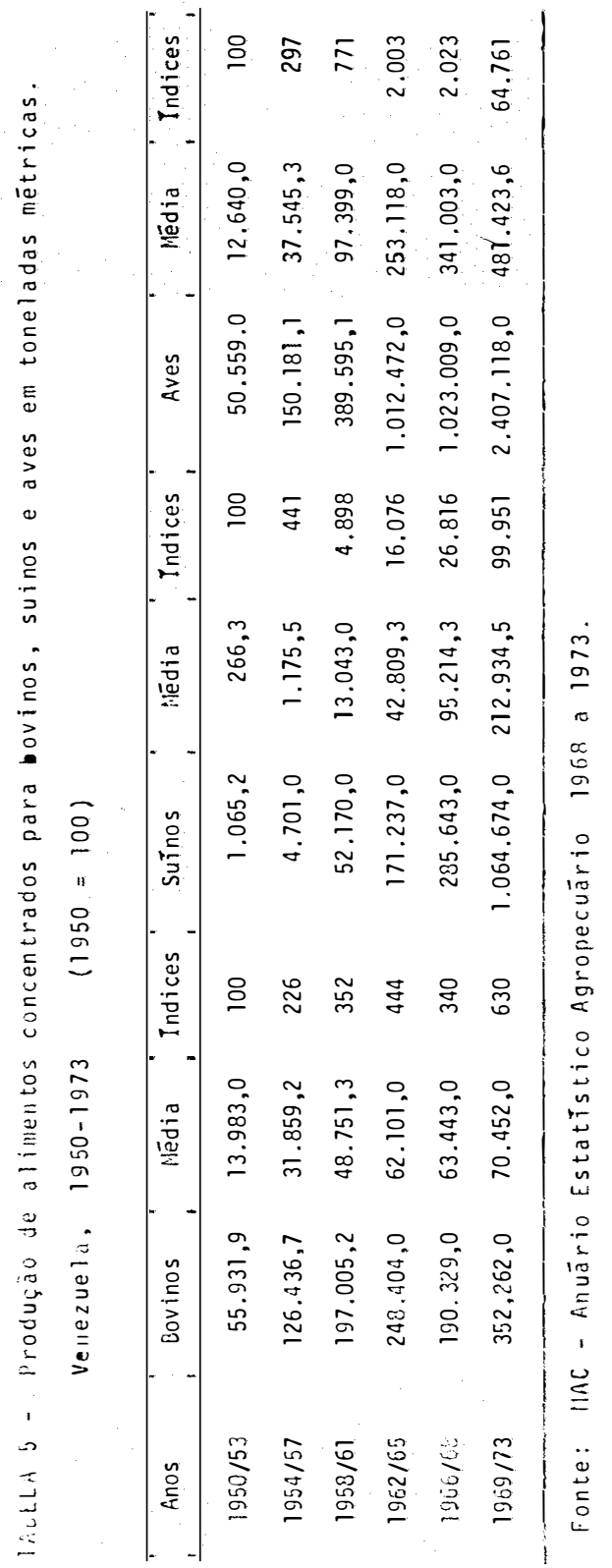


Como os aspectos anteriores, a mecanização agrĩcola apresenta progressos apreciāveis. A Tabela 6 demonstra esta observação. Os tratores, em geral, tēm aumentado de modo estimāvel ao passar sua importação de 735 em 1955 a 2.117 em 1973. Se for tomado o ponto médio durante os setēnios de 1955/ 61 e 1962/68, comprova-se uma importação anual de 897 tratores de roda para o primeiro setēnio, de 1.645 para o segundo, e de 2.586 para o quinquēnio final, o que significa um incremento sōlido, apesar de ponto médio dos tratores de esteira pa. ra os três períodos è de 326,142 e 219.

Em relação aos mesmos três lapsos de tempo, os pontos médios para arados são de 434 , 541 e 177 ; para grades de $660,1.035$ e 168 , para colhedeiras de 55 , 128 e 160 . Em consequēncia estes incrementos, como as cifras globais da Tabela 6 , comprovam a existência no pais, de numerosos instrumentos de produção mecānicos e modernos, ainda que seu uso es teja limitado ao setor empresarial.

Em vista da transcendēncia da mecanização no crescimento da agricultura capitalista, elaborou-se a Tabela 7 , a qual oferece estimativas sobre a ārea servida por māquinas den tro das terras de colheita nos anos $1965,66,67$ e 68 , e com discriminação das culturas principais. Em termos nacio nais pode-se constatar um aumento da ārea colhida de 1.627 .000 hectares para 1.851 .000 de 1965 a 1968 , ao lado de um incremento de 423.000 hectares mecanizados a 685.000. Não hā dūvidas de que a comparçaão entre ambos incrementos assinala um 







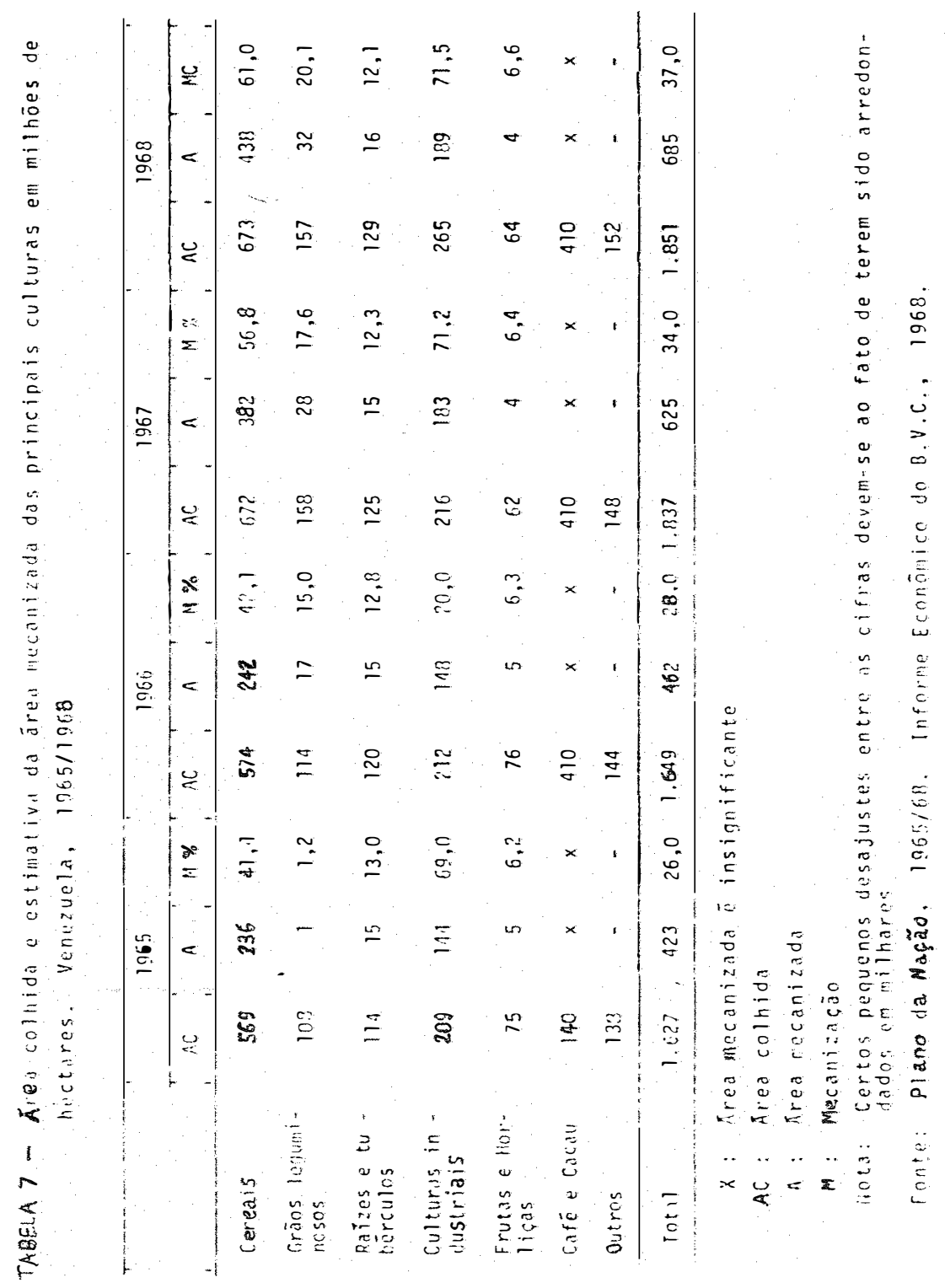


processo de intensificação mecānica, pois as taxas de incre mentos relativos são de 14 e de $62 \%$ respectivamente.

Essa intensificação sustentada são também manifestadas nas proporções que representa a superfície servida por má quinas em cada um dos anos em relação às extensões colhidas, pois, enquanto em 1965 significa $26 \%$, em 1968 equivale a $37 \%$.

A anālise do ocorrido em cada um dos grupos de diver sas culturas coloca em evidēncia o sentido capitalista do processo. Se de maneira geral e na relatividade das aproximações classificar-se esses grupos de culturas segundo as categorias de agricultores correspondentes,o resultado não pode ser outro senão o seguinte:

a - capitalista: culturas industriais (gergilim, algodão, arroz, fumo, cana-de-açūcar e, de certa maneira, milho).

b - camponesa: raîzes e tubérculos, grãos leguminosos.

c - latifundista: café e cacau.

Em sintese, segundo LOSADA (1976:65), "a anālise da ārea mecanizada põe em relevo, uma vez mais, o carāter capita lista desta e comprova, novamente, o caráter empresarial do processo agrícola que corre hoje na Venezuela. Esta conclusão é de decisivo significado, pois, a produção a base de māquinas constitui um dos componentes chaves da sociedade capitalista". 


\section{4 - Epílogo: Aprendendo do "Conuco"}

Depois de quase trinta anos sob a concepção tecnológica da mudança para o setor rural, a introdução de tratores, maquinarias, motores, ferramentas, herbicidas, fertilizantes químicos, sementes melhoradas, etc., fundamentada na politica de modernização, fez com que a atividade agrícola na Venezuela, se caracterize por uma desadaptação total ao meio físico tropical, tornando-se cada vez mais dificil sua recuperação.

Esta situação levou a pesquisadores, politticos, etc, interessados na problemática agrícola, a refletir sobre os re sultados até agora alcançados pela dita política em termos econōmicos e sociais, os quais, segundo a grande maioria, não têm sidos os mais lisongeiros, a nível camponēs.

o fracasso destas politicas e não outra coisa, tem sido desviado estrategicamente para o lado da ecologia tropical em relação com os sistemas de produção agrīcola. E assim que se fala agora, da pouca importāncia que a ciēncia agronōmica tem dado aos estudos dos sistemas agrícolas desenvolvi dos por comunidades indígenas, que vivem no trópico em equili brio com o meio natural; criticando-se a forma em que tais sis temas foram eliminados e substituĩdos sem análises prévias de sua significação e sua potencialidade.

A este respeito diz GONZALEZ (1977:1415), "se compararmos os resultados energéticos deste sistema agrícola primi tivo de nosso trópico, o 'conuco', com o sistema de produção de batatas da Inglaterra, obteremos uma simples explicação das 
vantagens da agricultura tropical. No 'conuco' se colheram 9.218 mega-calorias / ha, em forma de diversos alimentos, invertendo 561 Mcal em forma de trabalho, enquanto que na produ ção de batatas de clima temperado, 9.000 Mcal/ha/ano, com um subsídio energético em forma de energia do petróleo de 5.000 Mcal/ha".

Tais dados demonstram e levam ao reconhecimento, segundo o autor, de que os sistemas primitivos são mais eficien tes no uso da energia, e, alēm disso, não exigem,para produ zir, grandes insumos energēticos, mas foram condenado e relegados ao esquecimento, quando se sabe que esses princīpios tēc nicos e científicos sobre os quais estam firmados os 'conucos' constituem a chave para o desenvolvimento de uma agricultura autōctone e ajustada à ecologia venezuelana.

E assim como, debaixo desta perspectiva, setores interessados na questão camponesa tem deixado cair sobre a mesa uma "brithante idéia" que bem poderia constituir-se, segundo eles, na tābua de salvação de nosso camponēs e de nossa agricultura em geral, como é a possibilidade de resgatar e apro veitar cientificamente as prāticas agrícolas que, tradiciona 1 mente, nosso camponês vinha utilizando em seu meio.

Segundo esta alternativa, para incorporar o camponés ao processo de desenvolvimento, faz-se necessārio, então, a anālise cientīfica das tradições técnicas e culturais que ele representa; apresentando-se como problema politico, social, e conômico, científico e tecnolōgico. Em relação à colaboração 
que o camponés pode dar ao desenvolvimento agrícola venezuela no, o CONICIT-CENDES (1976:26) considera que "partindo de seu acervo técno-cultural se poderá desenvolver ciēncia e tecnolo gia para a produção agropecuāria, que servirá para determinar as possibilidades que existem de utilizar-se de seus conhecimentos e capacidade criativa atuais, na produção agrícola e num desenvolvimento científico e tecnológico que os incorpore como setores da experimentação e inovação agrícola".

0 sistema de produção tradicional que se conhece no pais e que tem sido utilizado pelo camponès venezuelano è o 'conuco', que definido por GONZALEZ (1978:34), "é um sistema de produção que consiste no desmatamento de pequenos lotes de terra dentro da selva, onde se semeiam diferentes plantas, as vezes intercaladas, cultivando-se por um tempo variāvel e quan do 0 solo se acha esgotado, abandona-se para começar-se de no vo o processo em outra parte $(\ldots)$ ".

Mas, o mais importante de tudo isto, è que o 'conu co' é uma atividade de subsistēncia bastante precária, porém, ainda assim, permite a sobrevivencia do camponēs e seu grupo familiar que, todavia, permanece no meio rural, aferrando-se com todas suas forças a esse pedaço de terra diante da ousa dia capitalista e a indiferença oficial.

Esta forma de trabalhar e cultivar a terra, por apre sentar um baixo nivel de desenvolvimento das forças produti vas e onde as relações de produção não vão além das familiares, pode ser incluida dentro da chamada agricultura "tradi - 
cional", a qual procurou-se e procura-se, ainda, eliminar,por meio da politica de modernização no transcorrer de todos estes anos.

Na atualidade rural venezuelana não è a situação do camponès e seu 'conuco' a que predomina; por conseguinte, uma generalização em torno do campones "conuquero", em relação à situação camponesa nacional, significa desconhecer a evolu ção das massas camponesas diante das mudanças que tếm ocorrido no pais.

Encarar a realidade camponesa, com relação a seus có nhecimentos e capacidade criativa, procurando enquadrá-la den tro de uma "cultura camponesa" diferente de nossa cultura urbana e moderna, è querer explicar a problemática mediante a concepção dos chamados "povos primitivos", proveniente da antropologia cultural americana, na qual, segundo HERNANDEZ (1976:9) "ao falar do camponès ou pequeno produtor faz-se referēncia a um ser abstrato, histōrico, social e economicamente indeterminado, do qual se pressupõe atitudes e situações e conómico-sociais inexistentes na realidade".

Continua o autor, dizendo que o mito da cultura camponesa, persistente e conservadora, apegada a suas próprias normas e tradições, não é mais que uma anālise transplantada, sem critério, para nossa realidade desde outras situações e contextos, sem responder em absoluto à evolução e a realidade atual do setor camponès venezuelano. 
Explicando além disso, que o processo de dissolução do camponēs tradicional, tal como se vem produzindo, é o que se chama "processo de proletarização e marginalização", que consiste no abandono progressivo por parte das grandes massas camponesas, de seu carāter de produtores independentes no con texto da pequena produção mercantil, voltada sobre a subsis tēncia e a desaparição progressiva das indūstrias domésticas, e os circuitos locais de comercialização, em função de sua in tegração ao mercado nacional como vendedores de força de trabalho e como consumidores de produtos de origem industrial.

Acontece, agora, que sem analisar as verdadeiras cau sas que explicam o que é, na atualidade, o camponēs venezuelą no, seu sistema de produção, o "conuco", passa a ser de um dia dia para outro, uma alternativa vālida para conseguir-se um autēntico desenvolvimento agrícola no trópico venezuelano,sen do talvez, uma saîda fácil de ocultar, ou na melhor das hipóteses, explicar o fracasso das práticas de "desenvolvimento" dirigidas ao setor camponēs.

Para HERNANDEZ (1976:18), "o caminho que hoje toma a capacidade criativa que o setor camponēs desenvolveu, dirigese, fundamentalmente, a obtenção de rendas a partir da venda de sua força de trabalho (...)" e não outra, devemos acrescen tar; portanto, querer recuperar a capacidade criativa do cam ponēs através do "conuco" nas atuais condições, é dar prova, uma vez mais, de não querer enfrentar a situação de explorado 
que vive o setor camponês no meio rural venezuelano por parte dos que governam o pais. 
89.

\section{CAPİTULO III - A FORMACÃO DO AGRÔNOMO NO CONTEXTO ZULIANO}

\section{1 - Considerac̃ões Gerais}

A educação superior, no que diz respeito à formação de profissionais para o setor agropecuārio e dentro do sistema científico e tecnológico do Estado de Zulia, estáre presentada pelas Faculdades de Agronomia e Ciências Veteri nārias da Universidade de Zulia, a Escola de Zootecnia da Universidade Rafael Urdaneta e os Colégios Universitários de Maracaibo e Cabimas, sendo a primeira instituição lembrada, a que, na realidade, centraliza a formação dos "recursos hu manos", agrônomos e veterinārios, a que a importante atividade agropecuāria desenvolvida na região, absorve em quase sua totalidade através dos organismos oficiais e empresas privadas ligadas ao setor.

$$
\text { Deve-se esclarecer que não se aceita a idéia de }
$$


qualificar o homem como um "recurso" a mais, dentro dos recursos naturais de um paîs, o qual pode ser manejado e admi nistrado a vontade e a critério de quem dirige um determina do processo de desenvolvimento.

$\mathrm{Na}$ ārea da investigação agropecuāria regional, 0 sistema conta com o Centro de Investigação Agropecuāria da Região Zuliana (CIARZU), dependente do Fundo Nacional de In vestigações Agropecuārias (FONAIAP); com o Instituto de Investigações Agronómicas da Faculdade de Agronomia e Faculdą de de Ciências Veterinārias da Universidade de Zulia e com a Fundação de Serviço para o Agricultor do Ocidente (FUSAGR I ) .

0 referido sistema, segundo VILLASMIL (1977:4), re ferindo-se às āreas de educação e investigação, apresentada mesma forma que em todo o pais, entre outras, as seguintes características:

a."os conhecimentos cientificos procedem, em boa parte, de sociedades estrangeiras, de correntes cientificas, tecnológicas e culturais de diferentes universidades norteamericanas, francesas e inglesas e muito pouco de centros na cionais e latinoamericanos.

b.o sitema foi concebido em função exclusiva da produção, in dependente dos fatores que geram as condições e modos de produção, chegando a isolar-se dos processos de industrialização agropecuāria, economia agropecuāria, de mobilização e participação social (...)". 
c. o sistema tem-se desviado na formação de técnicos para a produção e administração dos recursos que arbitra o setor oficial no campo agropecuário, vinculando-se uma boa porcentagem ao Estado como funcionārios técnicos, à educação universitāria, ao grande produtor e as suas prōprias explorações, esquecendo-se dos pequenos e médios produtores $(\ldots)$ ".

E evidente que os "recursos humanos" formados em um sistema com tais características, não passam de elementos, socialmente, neutros na perspectiva camponesa, incapazes de desenvolver qualquer atividade em beneficio das clas ses desprotegidas e da agricultura em geral, devendo-se isto à total desvinculação que existe entre os planos de estu dos e as necessidades reais do país, isto é, a problemática rural venezuelana; e o mais grave ainda, é que este é o "rẹ curso humano" que participa no desenvolvimento dos programas ou projetos que levam a cabo os centros de investigação da região; constituindo-se em elementos dināmicos na perspectiva capitalista.

Dentro deste contexto, pois, como jā mencionou-se anteriormente, encontra-se inserida a Faculdade de Agronomia da Universidade de Zulia, finalidade ültima deste trabalho. A citada Faculdade foi fundada em 1959, com a Escola de Engenharia Agronómica, atendendo a duas necessidades básicas:

a. a de formar agrotécnicos para uma região que, ao lado da 
exploração petrolīfera, estava desenvolvendo, em forma vị gorosa, uma agricultura e uma criação de grande projeção, mas, que não contava com o auxîlio necessárioda téc nica e, por outro lado,

b. a necessidade de realizar pesquisas cientificas e tecnológicas sobre os mūltiplos problemas que se apresentavam no processo de produção agropecuária na região, como fim de melhorar sua efetivação.

Desde esta data até nossos dias, a Faculdade de Agronomia vem recebendo um número cada vez maior de estudan tes, passando de 30 em 1959 para 1.200 em 1979, o que tem obrigado seus responsáveis a ampliar seu corpo docente, pas sando de 20 para 130 professores no periodo referido.

Desde sua fundação, a Escola teve como fim, "especializar" o aluno em determinadas áreas, sem descuidar, é $\underline{10}$ gico, da preparação geral durante os 5 anos de curso. Para optar pelo tîtulo de Engenheiro Agrōnomo, exige-se o cumpri mento de 200 unidades-créditos e de uma diversificação, sen do esta, inicialmente: Zootécnia, Engenharia Agrícola, Agro nomia, Ciências Sociais e Econômicas e Tecnologia Agropecuá ria. O currículo sofreu uma modificação em 1974, como consequéncia da inclusão, na carreira, de um ano de Estudos Ge rais, ano em que se inclui tambēm a Diversificação em solos. Na atualidade, a Faculdade de Agronomia se rege pe 10 plano de Estudos - 1978, o qual será resumido na tabe$1 \mathrm{a} 8$. 
TABELA 8 - Plano de estudos da Faculdade de Agronomia da Universidade de Zulia, Maracaibo - Venezuela. 1978

\begin{tabular}{|c|c|c|c|c|c|c|}
\hline \multirow{4}{*}{ Diversificação } & \multicolumn{6}{|c|}{ Disciplinas } \\
\hline & \multicolumn{2}{|c|}{ Biofisicas } & \multicolumn{2}{|c|}{ Socio-econōmicas } & \multicolumn{2}{|c|}{ Total } \\
\hline & \multicolumn{2}{|c|}{$\begin{array}{l}\text { Bāsicas + } \\
\text { Optativas }\end{array}$} & \multicolumn{2}{|c|}{$\begin{array}{l}\text { Bāsicas + } \\
\text { Optativas }\end{array}$} & \multicolumn{2}{|l|}{$\begin{array}{l}\text { Disci- } \\
\text { plina }\end{array}$} \\
\hline & Nūmero & $(\%)$ & Nūmero & $(\%)$ & Nūmero & $(\%)$ \\
\hline Agronomia & 53 & 93 & 4 & 7 & 57 & 100 \\
\hline Zootecnia & 54 & 93 & 4 & 7 & 58 & 100 \\
\hline $\begin{array}{l}\text { Engenharia } \\
\text { Agrícola }\end{array}$ & 50 & 93 & 4 & 7 & 58 & 100 \\
\hline $\begin{array}{l}\text { Ciēncias Sociais } \\
\text { e Econômicas }\end{array}$ & 47 & 73 & 15 & 27 & 56 & 100 \\
\hline Solos & 49 & 92 & 4 & 8 & 53 & 100 \\
\hline $\begin{array}{l}\text { Proteção de } \\
\text { Plantas }\end{array}$ & 52 & 93 & 4 & 7 & 56 & 100 \\
\hline
\end{tabular}

FONTE: Planto de Estudospara Egressos de Estudos Gerais. Faculdade de Agronomia de L.U.Z., Maracaibo

A tabela 8 é por demais esclarecedora da ênfase tẹ nológica na formação do Agrōnomo, com vistas à modernização do campo. Os alunos orientados em Agronomia, Zootecnia, Engenharia Agrīcola, Solos e Proteção de Plantas, tema obri gação de cursar e serem aprovados, em toda sua carreira, so mente em 4 disciplinas da área sócio-econōmica (7\%) contra um ponto médio de 52 (93\%) da àrea biofísica, sendo sabido, por parte das autoridades da Faculdade, da repercussão e de sequilibrios que a moderna tecnologia agrícola tem e oca- 
sionam no meio rural dos países subdesenvolvidos e da econo mia dependente, quando se introduz o uso indiscriminado de insumos tecnológicos, causando graves problemas sociais e ecológicos.

Com referēncia aos orientados em Ciēncias Sociais e Económicas, exige-se deles cursar e serem aprovados em 41 (73\%) das disciplinas da ārea biofísica contra 15 (27\%) de sua especialidade.

A partir desta perspectiva, passár-se-ā, então, a analisar um pouco mais a formação recebida pelo agrónomo na referida Faculdade.

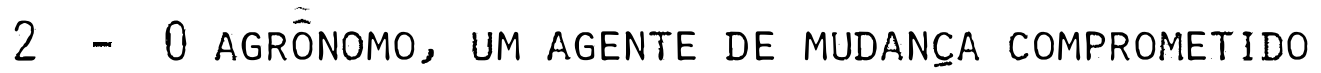

A maneira de revisão bibliogräfica, serão citados alguns autores que interessando-se pelo mesmo problema e que, além de assinalar as causas, tem trazido importantes contri buições para a formação do Engenheiro Agrōnomo que o paîs ne cessita.

Para YOPO (1971:15), "a importāncia e complexidade que o setor rural ainda tem e continuarā tendo em muitas dé cadas mais, concedem a este profissional uma linha de ação, sob certo ponto de vista, revolucionāria. Mas, para isto, faz-se mister a gestação de um novo Engenheiro Agrónomo que, alēm de técnico-produtor e científico, compreenda e implemente também a mudança estrutural-social". 
Para este autor, o papel do Engenheiro Agrōnomo não tem sido o mais adequado por duas razões fundamentais:

a. a deficiente e unilateral estrutura interna das Faculdades de Agronomia, especialmente, em seu ambiente (organi zação) acadēmico e curricular.

b. a pouca inquietude social e intelectual que o profissional da agronomia mantém em forma quase perseverante o que afeta concretamente a escassa liderança e participação que tem e já teve nos aspectos mais fundamentais que mar cam a politica e as decisões do país.

Continua dizendo YOPO (1971:7), "deve-se considerar que a tecno-estrutura concebe aos objetos como instrumentos seus, em outras palavras, os considera só em função dela mesma e não da sociedade global (...). Qualquer tecnoestrutura só procura colher cada vez mais riqueza e técnica, tudo sem significado algum ou, em certo sentido, periférico marginal, do qual apenas é dono só um reduzido nūmero de pessoas inseridas nos grupos de poder e de tomada de decisões". Isto vem sucedendo, segundo o autor, por causa da estrutura imóvel, não comprometida e conservadora das Facul dades de Agronomia que mais do que ninguém, lançam ao merca do um produto inerte do ponto de vista das maiorias campone sas e participe da tecno-estrutura e em nenhum modo, um indivĩduo consciente de sua grande função social.

Contudo, na realidade, a culpa não é toda do profissional de agronomia, ao considerarmos que as faculdades 
estão inseridas em uma estrutura maior que são as Universidades e que na Amērica Latina, salvo raras exceções, possuem uma estrutura conservadora, mais para os fins capitalistas, a Faculdade de Agronomia tem uma função bastante di nâmica e comprometida com os interesses da ideologia dominante, ao formar os agentes de mudança tecnológica que a tec no-estrutura exige.

A grosso modo, analisando-se a composição e estrutura de seu currículo, além de surgir este como rīgido e in flexível, é fácil notar a carēncia quase total da participa ção das ciências sociais. Esta característica histórico-cul tural se manifesta nitidamente no comportamento sócio-político e cultural dos profissionais; incapazes de sustentar uma anālise e conceitualização profunda da polaridade social que rege a maior parte dos paises, atuando de preferēn cia, dentro e para o "statu quod" e não para sua modificação.

Na opinião de ANEZ (1973:19), "a formação de Engenheiro Agrōnomo è deficiente. Durante sua passagem pela Faculdade de Agronomia, não se The ministra um embasamento so cio-económico forte que The permita lutar, com boas armas, no absorvente mundo que The vai tocar atuar. Não se thes mostra a situação de explorado que o paîs está vivendo; não se thes fala do dominio do poder por forças minoritārias in ternas que governam a nação pensando sō em seu prōprio bene fício; não se lhes ensina a dramātica realidade rural venezuelana; o enorme potencial de recursos humanos que existe 
no campo sem ser utilizado; a vida calamitosa em que passam seus anos; o marginalismo em que vivem; a carémcia de possi bilidades; a negação de oportunidades".

Para o autor, os programas da Faculdade de Agronomia năo correspondem às necessidades do paīs e nem à realidade rural. Sua concepção, diz ANEZ, reflete falta de humanismo. Considera que sō técnicas frias não podem consistir na formação de um profissional, que, pensa-se, vai-se por em serviço, através de suas diferentes atividades, no meio cam ponês do setor agrícola, onde uma grande quantidade dos prọ blemas que se apresentam, são fundamentalmente do tipo humano.

Considera alarmante a pouca carga de matérias de ca rāter socio-econōmico incluídas nos programas das Faculdades de Agronomia e, em especial, a Faculdade de Agronomia da Universidade de Zulia, a qual em 1973, somente tinha duas opções (Extensão Rural, Legislação e Direito Agrārio) para os orientados em Ciéncias Sociais e Economicas, que tratavam de aspectos sociais e, duas opções (Economia Agrícola e Administração Rural) que davam certa formação de caráter ecọ nōmico.

Desta forma, segundo ANEZ, é facilmente compreensī vel que um profissional com tão pouca instrução social e ecô nōmica, com tanto desconhecimento daqueles para os quais vai realmente trabalhar ou do que se formava em Engenharia Agro nōmica, seja "fagocitado" facilmente pelo deslumbrante e macio mundo que oferece o sistema. 
Até aqui concorda-se com o autor, mas falta apontar que esse é, precisamente, o tipo de agrōnomo que o sistema exige e que o papel da Faculdade de Agronomia como par te dele é, através de seus planos de estudo, formar esse pro duto que o mercado de trabalho estā exigindo. A "filosofia" e os "formosos princípios" que sustentam a profissãosão pre ciśamente esses e não outros. Não é o sistema que os absorve por não estarem suficientemente preparados para enfrentá-los, mas assim tem sido formados, para atender aos recla mos das classes dominantes ligadas ao campo e, portanto, pa ra a reprodução deste mesmo sistema.

A Sociedade Venezuelana de Engenheiros Agrónomos, (SVIA) - (1975:4), ante esta problemática, concorda em que "os formados nas Faculdades de Agronomia não podem escapar da situação vigente no pais, surgindo, então, mais como um produto para o sistema do que como um profissional destinado, por seus conhecimentos, à transformação do setor agrope cuārio venezuelano".

0 documento trata sobre a afirmação, bem conhecida, não se está formando o agrōnomo de que a Venezuela está necessitando e que, inclusive, esta situação tem sidoutí lizada como argumento para a criação de novas faculdades,es colas e até universidades, quando se deveria começar por uma anālise crítica das existentes.

Quanto à elaboração de Planos de Estudos e outros aspectos, nas Faculdades de Agronomia, opina a SVIA, que: 
a. em muito poucas oportunidades tem-se dado importāncia à opinião dos formados por essas faculdades.

b. com honrosas exceções, os professores universitärios têm se mantidos desligados da situação em que vive a agricul tura venezuelana;

c. a incorporação excessiva ao corpo docente de recém-forma dos, sem nenhuma experiēncia de campo, tem levado à formação de um plantel de professores inexperientes, repeti dores de livros escritos para outras circunstāncias.

Em relação à tendência que tem predominado nas Uni versidades para a organização curricular, segundo VILLASMIL (1977:9), "esta se caracteriza por:

a. separação entre docência e pesquisa;

b. a organização é por opções/disciplinas, quer dizer, conteúdos isolados;

c. enfatiza-se o conhecimento como "produto";

d. há um profissionalismo acadēmico dentro de um enfoque in dividual, desvinculado do meio sōcio-tecnológico;

e. os objetivos são específicos e;

f. os programas são rỉgidos, fechados".

Para finalizar, diante de toda essa problemática em torno da elaboração de planos de estudos, currículos, etc., OCHOA (1978:III.A.4.11), considera que "a elaboração de um currículo é um trabalho complexo, caso se quiser que sua organização seja científica e não arbitrāria. A maioria dos autores sobre organização curricular continua dizendo a 
autora, concordam que a dita elaboração inicia-se com a ană lise da sociedade e suas demandas futuras, quer dizer, que basicamente, a organização curricular está em função de:

a. o tipo de sociedade existente e

b. o tipo de sociedade desejada.

Na opinião da autora, um plano de estudo que tem de contribuir para preencher o vácuo existente entre a socieda de que temos e a que desejamos ter, deveria considerar ditos aspectos, pois, caso contrário proceder-se-ia por intui ção, pelo desconhecimento do que realmente quer-se transfor mar e até onde estariam dirigidos os esforços; que, para a anālise do tipo de sociedade existente e desejada, é necessārio fundamentar-se nos acontecimentos histōricos da realidade venezuelana, com ènfase no setor agropecuário.

\section{3 - Disciplinas Sociais versus Disciplinas Técnicas, UMA LUTA DESIGUAL}

Uma olhada na espetacular desproporção entre disci plinas socio-econômicas e biofisicas do atual plano de estu dos da Faculdade de Agronomia da Universidade de Zulia e e clarecendo um pouco mais o exposto na Tabela 8 , nos propor ciona a tabela 9 onde se indica também, o semestre correspondente para cada disciplina e seu valor ou peso em créditos.

A tabela 9 reflete uma situação concreta e tão evi 
TABELA 9 - Disciplinas bio-físicas e sōcio-econōmicas oferecidas pela Faculdade de Agronomia da Univers $\underline{i}$ dade de Zulia, Maracaibo - Venezuela, 1978

\begin{tabular}{|c|c|c|c|c|c|}
\hline \multicolumn{6}{|c|}{ Disciplinas } \\
\hline \multicolumn{3}{|c|}{ Bio-fisicas } & \multicolumn{3}{|c|}{ Sócio-económicas } \\
\hline $\begin{array}{l}\text { Semestre } \\
\text { Nümero }\end{array}$ & $\begin{array}{l}\text { Crédi to } \\
\text { Numero }\end{array}$ & Total & $\begin{array}{l}\text { Semestre } \\
\text { Nümero }\end{array}$ & $\begin{array}{l}\text { Credito } \\
\text { Numero }\end{array}$ & Total \\
\hline 30 & 19 & 6 & 60 & 3 & 1 \\
\hline 40 & 19 & 6 & 79 & 6 & 2 \\
\hline 50 & 26 & 8 & 80 & 6 & 2 \\
\hline 60 & 22 & 7 & 90 & 9 & 3 \\
\hline 70 & 27 & 9 & 100 & 20 & 7 \\
\hline 80 & 45 & 14 & & & \\
\hline 90 & 59 & 20 & & & \\
\hline 109 & 101 & 34 & & & \\
\hline \multirow[t]{2}{*}{ Total } & 317 & 104 & - & 44 & 15 \\
\hline & & $(86 \%)$ & & & $(14 \%)$ \\
\hline
\end{tabular}

Fonte: Plano de Estudos para Egressos de Estudos Gerais. Faculdade de Agronomia de L.U.Z., Maracaibo

dente que não merece muitos comentārios. A Faculdade de Agronomia oferece ao aluno, 104 disciplinas da área biofís $\underline{i}$ ca que representam os $86 \%$ do total contra 15 da área socioeconómica, os $14 \%$ restantes; isto representa um valor ou pe so de 317 unidades créditos contra 44. Por conseguinte, o aluno encontra na àrea biofísica maiores oportunidades de completar os 200 créditos exigidos, jáque dispõe de 117 créditos a mais. 
No caso em que o aluno mostre, de inicio, certa in. clinação para os aspectos sociais ligados ao campo, a Facul dade somente lhe oferece a oportunidade de consolidar seu interesse, no ūltimo ano de carreira $\left(9^{0}\right.$ e $10^{\circ}$ semestre $)$ on de se encontram concentrados aos $66 \%$ das disciplinas socio econōmicas oferecidas.

Ainda assim, fica quase impossivel que o próprio encaminhado a Ciências Sociais e Econōmicas, ao chegar ao ūitimo ano, consiga manter-se ou situar-se em uma posição critica das consequências sociais que determinada tecnolo gia possa trazer, devido ao bombardeio tecnológico a que se tem submetido e tem vindo suportando durante os primeiros anos, não dispondo, além disso, do tempo necessārio para a $\underline{s}$ similar e pesar criticamente, o conteúdo programático de ca da disciplina.

Isto não quer dizer, de maneira alguma, que se esteja contra a inclusão de novas disciplinas tecnológicas que merecem estar dentro do currículo de Agronomia, mas o que se quer, em todo caso, alertar, é que a Engenharia Agronomi ca è a carreira técnica de maior carga social; nas condições de subalimentação que afetam a mais de $70 \%$ da população venezuelana e especialmente as classes mais pobres do meio rural que contribuem consideravelmente para elevar os indices de desnutrição e morte no setor camponês, configura-se um campo de trabalho sumamente critico, exigindo, por conseguinte, um profissional da agronomia que se identifi- 
que plenamente com a realidade social que o rodeia e ponha em ação todos seus conhecimentos em busca de uma transformação total das condições existentes.

Outro aspecto bastante interessante, mostra-nos a tabela 10, onde, com os programas das disciplinas que temos à disposição, tratamos de analisar os objetivos perseguidos pelo professor ao elaborar seu programa, como também o ano em que dito programa foi aprovado pelo Conselho da Faculdade, reconhecendo desta forma, estar de acordo com seu conteūdo e autorizando-o para sua execução. Com relação à anālise dos objetivos, consideramos importante porque acredita mos encontrar nos mesmos, alguma justificação social por parte das disciplinas da ārea biofísica, o que resultou desalentador, pois, os objetivos não existem.

De 86 programas, $80 \%$ não enunciam os objetivos que o professor da disciplina.pretende alcançar em relação a seus alunos; esta situação nos faz pensar e concordar que a avaliação dos conhecimentos adquiridos pelo aluno, semestral ou final, não tem razão de ser, visto que o professor não sabe que aspectos avaliar e o aluno não sabe em que aspectos vai ser avaliado. Este impasse se dá porque são os objetivos, gerais ou específicos, os quais na realidade, orientam o sistema de avaliação no processo ensino- aprendizagem, servindo de guia tanto ao professor como do aluno. Portanto, um programa que não exponha em forma clara e precisa seus objetivos, revela uma falta grave na elaböração dos mesmos. 


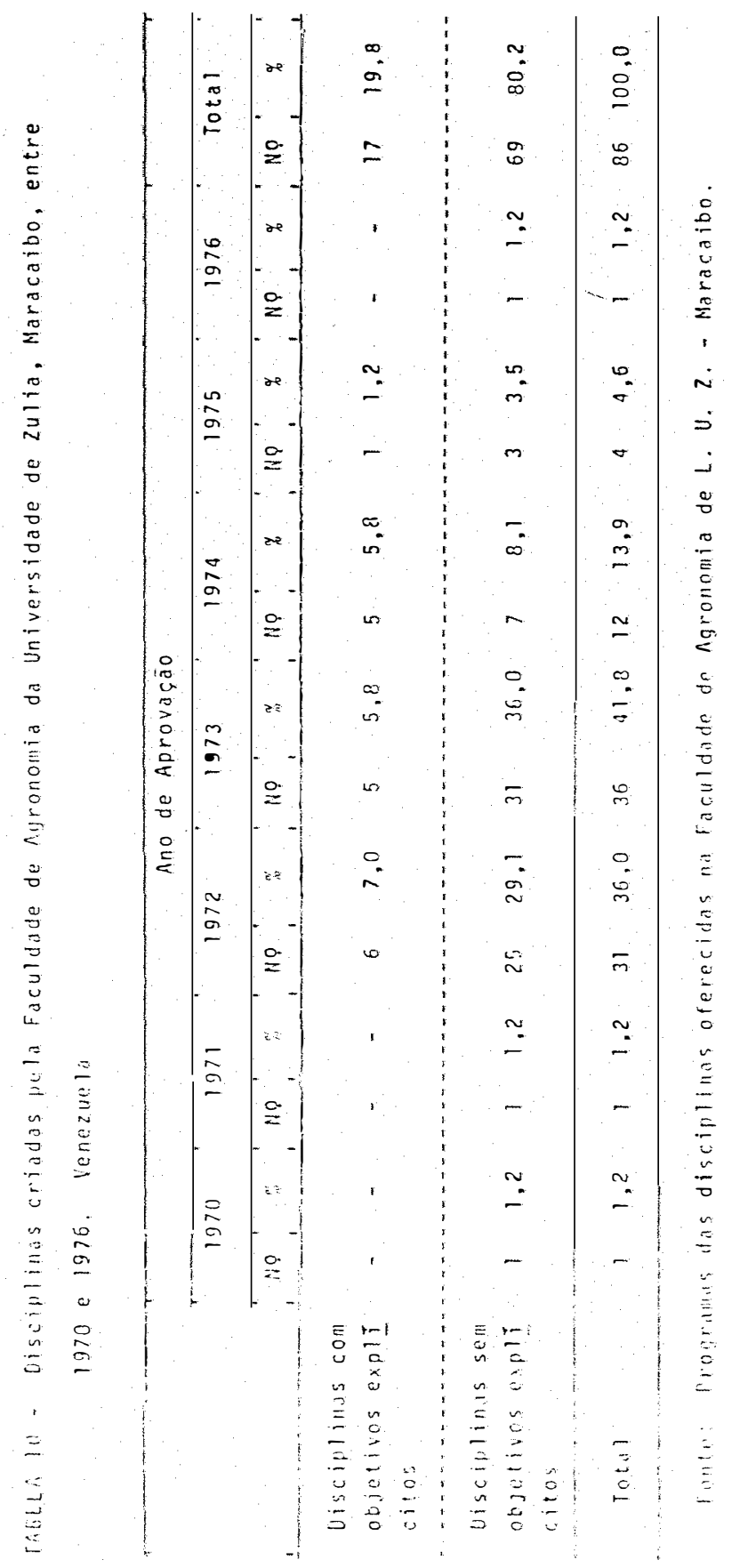


A não inclusão dos objetivos nos programas das dis ciplinas de carāter tecnológico, pode ser que esteja relacionada com a visão do mundo que o professor tenha, e consi derar assim que repartir conhecimentos tecnológicos não exi ge nenhuma preparação especial de sua parte e muito menos quando o professor tenha realizado sua pós-graduação em pá̃ ses altamente tecnificados em agricultura.

Segundo dados da tabela 11, na Faculdade de Agronomia, de seus 54 professores que têm realizado cursos de especialização, 40 têm escolhido universidades de paîses de Senvolvidos ( 37 nos Estados Unidos, 1 em França, 1 na Ingla terra e 1 na Holanda) ou seja, uns $74 \%$; enquanto que os $26 \%$ restantes, têm-no realizado em paìses latinoamericanos ( 3 na Venezuela, 3 no Brasil, 3 no México, 3 em Costa Rica, 1 em Porto Rico e 1 na Colómbia).

Todos sabem que, muitas vezes, os cursos de pósgraduação constituem urra forma de penetração importante de ideologias extranhas ao pais, porque, essas pessoas, ao regressarem, muitas vezes, constituem-se em portadoras e defensoras eficazes da cultura e ideologia dos paises desenvolvidos, especialmente, o norteamericano.

Reconhece-se e isto é verdade, que geralmente, o professor de Agronomia é um profissional da Engenharia que não têm sido preparado para o trabalho docente e que por es ta razão, não tem a mĩnima idéia de como se organizar um programa; mas, também, é verdade que para isso existe um De 
TABELA 11 - Número de professores e paīses onde realizaram cursos de especialização. Faculdade de Agrono mia da Universidade de Zulia, Maracaibo - Vene zuela, 1978

\begin{tabular}{lccc}
\hline \multicolumn{1}{c}{ Paises } & \multicolumn{2}{c}{ Professores } \\
\cline { 2 - 4 } & Nümero & Porcentagem \\
\hline Estados Unidos da América & 37 & 68,6 \\
França & 1 & 1,8 \\
Inglaterra & 1 & 1,8 \\
Holanda & 1 & 1,8 \\
Venezuela & 3 & 5,6 \\
Brasil & 3 & 5,6 \\
México & 3 & 5,6 \\
Costa Rica & 3 & 5,6 \\
Porto Rico & 1 & 1,8 \\
Colómbia & 1 & 1,8 \\
\hline \multicolumn{1}{c}{ Total } & 54 & 100,0 \\
\hline
\end{tabular}

Fonte: Dados fornecidos pela Direção da Faculdade de Agronomia da L. U. Z., Maracaibo

partamento de Coordenação Docente e uma Direção cuja função é a de buscar as soluções que eliminem este tipo de falhas elementares e lamentáveis em um centro de educação de nível superior.

Outro aspecto mostrado pela tabela 10, é a permanência dos mesmos programas sem sofrer nenhuma revisão ou modificação no temário. A grande maioria dos programas fo- 
ram aprovados entre os anos 1972 e 1973, ou seja, jā transcorreram 8 ou 7 anos e continuam em vigência. Num final de século tão dinâmico como o que estamos vivendo, os conhecimentos, tanto cientificos-tecnolögicos como suas consequências na estrutura econômica e social dos países, tornam-se por demais decisivos na configuração de uma sociedade mundial cada vez mais desigual.

Um programa que permaneça igual durante 8 ou mais anos, tem perdido todo contacto com a realidade social que muda aceleradamente; seu conteúdo se torna obsoleto e o alu no que o recebe, tambēm, não pode compreender quais são e de onde vêm as forças que determinam o contexto social que o rodeia.

A Faculdade de Agronomia da Universidade de Zulia tem contribuído na formação de 489 Engenheiros-Agrōnomos em 13 formaturas até 1976. A tabela 12 nos mostra esta relação.

Como pode-se observar, o número de orientados em Ciências Sociais e Econômicas ocupa o segundo lugar com $22 \%$ após Agronomia com $36 \%$, mas se seguirmos mantendo o critério até agora estabelecido, ou seja, o de comparar todas as orientações da área biofísica com as da área socio-econōmica, o resultado será sempre o mesmo, isto é, o caráter tecnológico dado na formação do agrōnomo, pois, somadas as por centagens, os orientados em biofísicas representam $78 \%$ contra $22 \%$ de orientados em socio-econômicas. 
TABELA 12 - Número de Engenheiros Agrōnomos formados peía Faculdade de Agronomia da Universidade de Zulia, Maracaibo, Venezuela. 1964-1976

\begin{tabular}{|c|c|c|c|c|c|c|c|}
\hline \multirow[b]{2}{*}{ Ano } & \multicolumn{4}{|c|}{ Diversificaçōes } & \multicolumn{2}{|l|}{$(t)$} & \multirow[b]{2}{*}{ Total } \\
\hline & Agron. & $\begin{array}{c}\text { Cs. Eco. } \\
\text { Econ. }\end{array}$ & $\begin{array}{l}\text { Ind. }{ }^{++} \\
\text {Lac. }\end{array}$ & $\begin{array}{l}\text { Engo } \\
\text { Agro }\end{array}$ & Solos & Zoot. & \\
\hline 1964 & 7 & - & 3 & 4 & - & 4 & 18 \\
\hline 1965 & 13 & 3 & - & 5 & - & 2 & 23 \\
\hline 1966 & 10 & 8 & - & 9 & - & 7 & 34 \\
\hline 1967 & 12 & 7 & - & 9 & - & 4 & 32 \\
\hline 1968 & 17 & 4 & - & 9 & - & 6 & 36 \\
\hline 1969 & 20 & 2 & - & 6 & - & 9 & 37 \\
\hline 1970 & 12 & 11 & - & 1 & - & 4 & 28 \\
\hline 1971 & 19 & 9 & - & 4 & - & 12 & 44 \\
\hline 1972 & 18 & 14 & - & 12 & - & 6 & 50 \\
\hline 1973 & 18 & 11 & - & 11 & - & 6 & 46 \\
\hline 1974 & 16 & 21 & - & 6 & - & 10 & 53 \\
\hline 1975 & 7 & 13 & - & 5 & 6 & 9 & 40 \\
\hline 1976 & 8 & 7 & - & 12 & 9 & 12 & 48 \\
\hline \multirow[t]{2}{*}{ Total } & 177 & 110 & 3 & 93 & 15 & 91 & 489 \\
\hline & $(36 \%)$ & $(22 \%)$ & $(1 \%)$ & $(19 \%)$ & $(3 \%)$ & $(19 \%)$ & $(100 \%)$ \\
\hline
\end{tabular}

(+) Atualmente oferece-se a Diversificação em Proteção de Plantas a qual não tem formado seus primeiros especialistas.

$(++)$ Esta diversificação não se oferece atualmente.

(+++) A orientação em Solos começou a ser oferecida em 1973, portan to seus primeiros especialistas sairam em 1975.

Fonte: Departamento de Coordenação Docente. Faculdade de Agronomia da Universidade de Zulia. Maracaibo. 
A predileção pelas diversificações de carāter tecnológico, por parte dos alunos, reflete as caracteristicas de modernização que prevalecem no setor agrīcola venezuelano. Uma razão disto deve-se tambēm às poucas disciplinas ofe recidas pela Faculdade de Agronomia que se relacionam com as questões económicas e sociais ligadas à agricultura, as quais somam 15 entre obrigatórias e optativas o que significa pouca ou nenhuma outra alternativa de escolha por parte do aluno. Ou pode ser, tambēm, que estas poucas discipli nas não tenham um conteúdo programático que desperte o inte resse, que leve ao aluno a manifestar-se criticamente diante dos problemas levantados pelo professor, levando-os a es colher a orientação social.

Destaca-se, que o reduzido número de disciplinas da área socio-econōmica, não è o que na realidade interessa, e sim, seus conteúdos programáticos, os quais estão ade quados ao agrônomo que o sistema social vigente exige.

Assim, por exemplo, a Extensão Rural como discipli na básica na formação do agrōnomo tem sua razão de ser como instrumento na difusão da nova tecnologia agricola no meio rural. A Sociologia Rural, baseada na Sociologia que elaborou os conceitos teóricos do dualismo social, a modernização, etc., proporcionam os elementos teöricos que condicionam o aluno à aceitação de uma situação social no meio rural que não é a real, na perspectiva đas classes ou setores dominados. 
110.

Devido à relação entre a problemática abordada nes te trabalho e a Extensão Rural, realizou-se uma revisãomais detalhada dos conteúdos programáticos das disciplinas Exten são Rural I e II, vigentes na Faculdade de Agronomia da Uni versidade de Zulia.

Assim observa-se que, no programa de Extensão Rural I e na parte correspondente à sua justificação, PROGRAMA (1972:1), diz que "está provado que para alcançar o desenvolvimento desejado nos países de baixos níveis económicos, sociais, educacionais, etc., é imprescindivel que se leve a cabo um Programa de Extensão. A Venezuela está : incluida entre estes paises em vias de desenvolvimento e que sem o concurso da Extensão Rural, não poderá alcançar os objetivos fundamentais de melhorar os trabalhos do campo e as condições de vida do homem do meio rural, através de uma ação educativa ajustada à realidade".

Deve-se esclarecer que não estā-se duvidando da im portāncia que a Extensão Rural possa ter na formação do agrô nomo. 0 que se critica neste programa e que não se explica, nos seis temas propostos é, por que razão a Venezuela se en contra entre os paises de baixo nível econômico, social, etc., e por que, sem conhecer estas causas, sem ter um conhecimen to prévio da problemática rural, o fracasso evidente da Reforma Agrāria, etc., justifique a realização de um Programa de Extensão.

Se no país está-se levando a cabo um Programa de 
Reforma Agrāria, a colaboração da Extensão Rural à mesma é a de "melhorar as condições de vida do homem rural", mas sa be-se por HERNANDEZ (1977:7-8), citado no capitulo anterior, que existe uma grande variedade de "homens" nomeior ral venezuelano, como são os grandes produtores agrỉcolas, os grandes criadores de gado, os grandes possuidores de ter ràs ou latifundiārios, os médios agricultores, os camponeses, os "conuqueros" etc..

Em todo caso, se o conceito de "homem rural" do Pro grama de Extensão citado, refere-se ao camponês em algumas de suas modalidades, é de todos conhecido que na Venezuela o camponês tem sido o grande ausente nos Programas de Refor ma Agrāria oficial. Se é assim, a colaboração da Extensão Rural está orientada a outros setores sociais do meio rural e não precisamente ao camponês.

Visto assim, nunca se hā de chegar a um trabalho ao nivel do camponès. Referindo-se aos serviços de Extensão na Venezuela, diz HERNANDEZ (1976:33), "a experiência da ü tima década demonstra que não tem-se atingido os objetivos propostos porque o homem camponès ainda não tem atingido o desenvolvimento integral, nem muito menos elevado a produção e, com ela, o nĩvel de vida. A Extensão se tem ocupado em transmitir uma tecnologia inadequada a nossocontextosocio-cultural; muitas das vezes, supondo que o camponésé uma "caixa aberta" pronta para receber toda informação e adotā-la, mas negandoThe participação em todo processo deliberativo, reflexivo e criativo". 
o Programa de Extensão também não esclarece a que "realidade" deve estar ajustado o trabalho educativo por meio da Extensão Rural, se é a realidade que apresenta como característica principal a dinamização do moderno desenvolvimento capitalista na agricultura ou se é a outra realidade que o Estado nega, isto é, aquela cuja caracteristica principal é a proletarização e a explớração camponesa.

Além disto, no Tema 5 do Programa de Extensão Rural I, hã uma manifesta supervalorização da Extensão Rural com realação à Sociologia Rural, em outras palavras, a ciēn cia determinada por um instrumento técnico metodológico, o que mostra a importāncia dada à Extensão por parte dos orga nismos Internacionais já analisados, notando-se, em seu con teūdo, a influência da sociologia rural americana.

$$
\text { E assim como, ao referir-se ao papel que tem o "li }
$$
der" nos Programas de Extensão, O Extensionista como agente de mudança, que trata de atingir mudanças de valores e atitudes, segundo PINTO (1972:6), "sabe que necessita tanto do apoio dos grupos sociais já presentes, como a formação de līderes da "comunidade", para que sua ação não permaneça lí mitada a influenciar pessoas isoladas, mas sim a pessoas que possam influenciar outras".

Ao referir-se a ação de mudança, segundo o Programa, esta está dirigida ao aspecto socio-cultural e não ao econômico, em outras palavras, a mudança a nivel de superestrutura e não ao nỉvel de estrutura. 
Em 1976, elaborou-se um novo Programa de Extensão Rural I constituỉdo por 7 unidades temáticas repartidas entre 4 professores segundo o aspecto a ser tratado. Isto demonstra a preocupaçäo de atingir uma melhor organização no ensino da disciplina, não obstante, alguns aspectos do temá rio continuem sendo enfocados conforme os principios clássi cos da Extensão Rural americana, sobre tudo o que se refere a metodologia a ser utilizada.

Como este novo Programa também, apresenta a mesma falha que os demais programas da Faculdade, ou seja, a ausência dos objetivos a serem alcançados pela disciplina, tor na-se dificil realizar uma análise mais detalhada do mesmo.

0 Programa de Extensão Rural II segue a mesma estratégia que o anterior, fazendo ressaltar a importāncia de agrupamentos que, como os Clubes $5-V$, os Clubes de Donas de Casa, etc. são fundamentais nos trabalhos de Extensão. Isto é assim, porque, segundo PINTO (1972:6), "a organização de grupos de homens, mulheres e jovens, representa um.mecanismo de persuasão, nos quais, pela mesma ação dos grupos, é mais fácil produzir a mudança de atitudes e valores e elevar aspirações e motivações".

Os Programas de Extensão Rural encontram nos jovens e mulheres, uma melhor receptividade a mudança proposta, os quais poderão, mais tarde, influir para que os campo neses mais velhos adiram ao mesmo.

E evidente que a Extensão sabe que a maioria dos 
camponeses reagem negativamente a adoção de novas práticas agrỉcolas, mas não porque não estejam interessados nas mesmas, senão por duas razões fundamentais e amplamente justificadas:

a. sua atitude manifesta de desconfiança em toda iniciativa, que provenha dos organismos oficiais, devido aos longos anos de enganos e mentiras de que tem sido vitima e, por outra parte,

b. adotar uma nova prática agrícola, por mais simples que se ja, significa, para muitos, investir os poucos recursos de que dispõem em insumos altamente extorsivos, convertendo-se a agricultura em uma atividade de grandes riscos e de muitas decepções por parte dos pequenos agricul tores; mais ainda, quando a agricultura que se pratica no país é uma agricultura de aventura, na qual o lucro fácil é sua meta final.

Bem diz GONZALEZ (1977:5), "o camponês sabe quando está informado que os sistemas melhorados de produção rẹ querem inversões substanciais em certos insumos, por conseguinte, devido à incerteza das chuvas, do mercado e sua prō pria destreza e conhecimentos, não arrisca sua precária eco nomia para a adoção destes novos sistemas".

Fechamos este capitulo com uma citação que resume toda a amarga verdade do difuso papel, até agora, desempenhado pelo Engenheiro-Agrōnomo, na reflexão autocrítica de GONZALEZ (1978:42), "esta euforia de modernização deu ori- 
gem e foi seguida pelas Escolas de Agronomia e Veterinārias, onde se copiavam os programas de estudos de escolas similares norteamericanas. Assim nós formamos os profissionais do agro. Nós nos especializamos no Norte ou na Europa e com es ta bagagem começamos a atuar e continuamos atuando". 


\section{CAPİTULO IV - CONCLUSÕES E SUGESTÕES}

\section{1 - Conclusoẽs Gerais}

No Capítulo I, através de uma revisão selecionada dos documentos à disposição, procurou-se analisar e discutir os interesses de classes que, dentro do esquema ideológico capitalista, dinamizavam o processo de modernização da agricultura latinoamericana; ao ser considerada esta como sendo uma atividade marcada dentro de um contexto social "tradicional e atrasado", que mediante uma ação de mudança poderia proporcionar um melhor nîvel de vida ao camponés e um maior impulso à economia dos países subdesenvolvidos.

Tratou-se, por conseguinte, de demonstrar o verda deiro significado de alguns conceitos teóricos sociológicos 
que, como sociedade dual, modernização, mudança e estrutura social, foram elaborados e manipulados ideológicamente por inūmeras instituições internacionais, convertendo-se em poderosos instrumentos na reprodução das relações de produção, que o novo centro hegemōnico da economia exigia, para lograr sua consolidação como primeira potência capitalista a nỉvel mundial, representado pelos Estados Unidos da América.

Esta discussão justificou a formulação de nossa hị pótese central, de que o agrōnomo, no caso particular da Venezuela, recebia uma formação acadêmica dirigida à implementação da polîtica de modernização e, portanto, à reprodução das relações de produção capitalistas no meio rural venezuelano.

Para a posterior avaliação e comprovação desta hipótese, no Capítulo II procedeu-se a anālise de alguns aspectos da atual politica agrícola implementada pelo governo venezuelano. Esta situação demonstrou à estreita relação que sempre existiu e sempre existirā, entre os governos "democráticos" que se tem sucedido no poder e as classes privile giadas que, dominando a vida econômica e política, são as que decidem em matéria de desenvolvimento agrīcola, onde a modernização do setor é o objetivo a ser alcançado.

Além disso, tratou-se de caracterizar a situação atual do meio rural e onde se deixou ver, como é o setor agroindustrial e a empresa agrícola moderna e capitalista 
os que, fomentados pelo próprio Estado, dominam a produção agropecuária do país, submetendo os outros setores sociais a desiguais condições econômicas e sociais.

Verificou-se assim que, para a atividade agrícola ter alcançado tal grau de modernização, teve de contar com a colaboração do Estado através das instituições que formam o sistema, como é o Ministério da Agricultura e as Universidades. A Universidade em seu papel de produtora, por intermédio das Faculdades de Agronomia, forma o agrônomo-reprodutor, o qual o Ministério da Agricultura emprega e que as classes dominantes ligadas à agricultura moderna exigem e usufruem.

Chega-se assim ao Capítulo III, no qual mediante uma rápida e simples anālise do Programa de Estudos vigente na Faculdade de Agronomia da Universidade de Zulia, conseguiu-se captar em forma surpreendente e evidente, a manifes ta tendencia de formar um profissional altamente capacitado em técnicas, para engajar-se dentro da tecno-estrutura vene zuelana.

Por outro lado, decorrente do mesmo fenômeno e que demonstra a parcialização por parte da Faculdade com a ideo logia dominante, verificou-se a quase ausência no Plano de Estudos analisado, de disciplinas que tratem de aspectos so ciais, econômicos, etc., sabendo-se antecipadamente que é no meio rural que essas variáveis se tornam mais conflitivas de vido a desigualdades em relação a propriedade da terra. 
0 agrōnomo assim formado, sem dūvida alguma, não deixa de ter um papel importante no processo de mudança social, mas não na perspectiva do setor dominado, segundo a classificação de Hernandez.

\section{2 - Sugestões}

Sobra uma tarefa bastante dificil: sugerir algumas alternativas para a solução da problemática levantada neste trabalho. Num país, como a venezuela, considerado como mode 10 da politica que desenvolvem fundamentalmente os Estados Unidos em relação aos paises dependentes, nos quais se veri fica com mais clareza as medidas impostas desde os centros dominantes do capitalismo internacional, qualquer solução nas atuais condições, repete-se, não passaria de um paliativo que não levaria a nada de concreto. Exemplo disto é a lamentável realidade polittica, económica, social e cultural do paîs, depois de 20 anos de governos "democráticos".

$$
\text { Quer-se deixar bem claro que a problemática aqui }
$$

discutida não se resume única e esclusivamente ao profissio nal de agronomia. Em outras palavras, não é o agrōnomo a única vitima de uma polittica educativa comprometida com as exigéncias de uma minoria privilegiada, atravēs da institui ção universitária, pelo contrário, a ideologia dominante alcança todos os profissiona is por igual, cada um em sua ārea de trabalho contribui na reprodução de um sistema social que os forma e os deforma ao mesmo tempo. 
Em nenhum momento, foi intencional agredir o agrōnomo ou denegrir a Faculdade de Agronomia; ou que este trabalho seja considerado anti-modernização, anti-extensão ou anti-tecnológico; não é isto que pretendeu-se. Seria absur do e ridículo, estar contra uma maior produção e a investigação agropecuāria, quando se sabe que, inevitavelmente, a àtividade agrícola continuará sujeita aos caprichos da natu reza e que uma população cada vez maior, como a venezuelana, exige mais e melhores produtos alimenticios.

Fica-se, isto sim, contra os interesses que se movem por trás da estratégia modernizadora da agricultura; da queles setores minoritários que se utilizam da Faculdade de Agronomia e de seus formados para estruturar de tal forma a atividade agricola, a fim de elevar suas taxas de lucro a custa da exploração de uma grande maioria de venezuelanos do meio rural. 


\section{S UMMARY}

In this work, it was discussed the importance of the academic formation of the student in Agronomy, for the execution and modernization of agriculture. In the specific case of Venezuela, it was taken, as the point of reference, the formation given at the College of Agronomy, University of the State of Zulia, Maracaibo, Venezuela.

Such formation is a manner to specialize "human ressources" in agricultural techinic, not with the aim to help the venezuelan peasant and to improve their actual condictions of life, but, at the contrary, such formation is directed to the reproduction and consolidation of the capitalist relation ships of production being in force at the rural conditions of the capitalist ideology, based on the theories of dual society modernization and social change. 
To confirm this principal thesis, many documents were consulted and analysed, which gave the theoretical basis of the policy of agricultural modernization in Latin America. From those documents, some aspects of the actual venezuelan agricultural policy and the most important characteristics of the rural conditions were analysed, as a direct consequence of modernization. The analysis of the plan of Studies which is being actualiy followed by the mentioned College of Agronomy in the formation of the Agronomist, was also made.

Finally, it became evident the technicist formation of the student of Agronomy taking aim at the obtention of a product highly specialised with the most sophisticated technics, which can be adopted and utilized, only, by a dominant and powerful small fraction of the people, accentig better the social and economic differences between the differents sections which compose the social structure of the venezuelan rural conditions.

In conclusion, the student in Agronomy at the Univer sity of Zulia, is prepared to become an agent for technological transformation and not an agent for structural change that the country needs for its total independence, according to its undeveloped condition. 
123.

B I BLIOGRAF I A

A. L. E. A. S. (Associaciōn Latinoamericana de Educaciōn Agrî̀ cola Superior), 1978. VI Conferência. Acta Final. Tomo I. Maracaibo.

ANEZ, D., 1973. El Ingeniero Agrónomo que necesitamos formar. C.I.D.I.A.T., Universidad de los Andes. Mimeo. 44 pp.

B.C.V. (Banco Central de Venezuela). 1976, Informe Econōmico. Caracas, $396 \mathrm{pp}$.

C.E.P.A.L. (Comissiōn Econōmica para Amērica Latina), 1948. La Obra de las Naciones Unidas. Depto. de Informaciōn Pü blica. O.N.U. New York, 22 pp.

CHOSSUDOVSKY, M., 1977. La miseria en Venezuela. Vadell Hermanos Editores. Valência, $265 \mathrm{pp}$. 
C.O.N.I.C.I.T. - C.E.N.D.E.S. (Consejo de Investigaciones Ci entificas y Tecnológicas - Centro de Estudios del Dessarrollo), 1976. Qué hacer con la agricultura venezolana? Mimeo. Caracas, 42 pp.

COSTA-PINTO, L. A., 1967. O desenvolvimento: seus processos e seus obstāculos. In: Teoria do Desenvolvimento. Zahar Edi tores. Rio de Janeiro, 201 pp.

COSTA-Pinto, L. A., 1967. Modernização e Desenvolvimento. Ibidem.

DUNCAN, J., 1964. Princípios bāsicos de Extensão Rural. U. R.G.S., Depto. de Ciēncias Socias. Porto Alegre, 89 pp.

F.A.0. - I.I.C.A. (Organización de las Naciones Unidas para la Agricultura y la Alimentación - Instituto Interamerica no de Ciências Agrícolas). I a Conferéncia Latinoamericana sobre Educación Agrícola Superior. Chile, 1958.

F.A.0. (Organizacion de las Naciones Unidas para la Agricultura y la Alimentaciōn), 1971. La Extensiōn Rural en América Latina y El Caribe, Roma, 225 pp.

FEDER, E., 1977. Penetraciōn de las Transnacionales en la agricultura latinoamericana. In:0piniōn Agrāria. Enero, Ano IV, no 11. Caracas, $96 \mathrm{pp}$.

GONZALEZ, H., 1978. Venezuela, agricultura y soberanía. S.V.I.A., $95 \mathrm{pp}$. 
GONZALEZ, J. E., 1977. Anālisis de la actividad de investigación agrícola en Venezuela. Seminario LUZ - CONICIT CENDES. Mimeo. Maracaibo, 24 pp.

HERNANDEZ, R. de, 1976. Analis is de la transferencia de ciencia y tecnologia para el sector agrícola. Seminārio CONICIT-CENDES. Mimeo. Caracas, 54 pp.

HERNANDEZ, J.L., 1977. Las fuerzas sociales en el campo ve nezolano. In: Opiniōn Agraria. Enero, Año IV, No 11. Ca racas, $96 \mathrm{pp}$.

HERNADENZ, J. L., 1976. Problemas planteados por la proleta rización del campesinado para su incorporación al desar rollo de tecnologia agricola. Seminario CONICIT-CENDES. Mimeo. Caracas, $19 \mathrm{pp}$.

IANNI, 0., 1976. Sociologia da Sociologia Latinoamericana. Editorial Civilização Brasileira, S.A., Rio de Janeiro, $186 \mathrm{pp}$.

JATEM, D., 1976. La politica y programas del Gobierno. Seminārio CONICIT-CENDES, Mimeo. Caracas, 42 pp.

LAMBERT, J., 1974. Obstáculos ao desenvolvimento decorren tes da formação de uma sociedade dualista. In: Sociologia do Desenvolvimento. Tomo I. Zahar Editores. Rio de Janeiro. $130 \mathrm{pp}$.

LOSADA, A. R., 1976. La tierra venezolana en la dialéctica del subdesarrollo. U.C.V. - Divisiōn de Publicaciones. Tomos I y II. Caracas, 262 pp. 
L.U.Z. (Universidad del Zulia), 1978. Plan de Estudios para Egresados de Estudios Generales. Facultad de Agronomia. Maracaibo. $14 \mathrm{pp}$.

L.U.Z. (Universidad del Zulia), 1972. Programa de Extensiōn Agricola I e II. Facultad de Agronomia. Maracaibo, 9 pp.

MARTEL, A., 1976. La agricultura, entre la carraplana y el despelote. Editorial Lisbona. Caracas, $116 \mathrm{pp}$.

MAUNDER, A. H., 1973. La Extensiōn Agrícola. F. A. 0. Roma $289 \mathrm{pp}$.

NERY, B., 1978. Educación Formal y Dependencia in Revista de la VI Conferencia Latinoamericana de Educación Agrícola Superior. ALEAS. Maracaiba, $30 \mathrm{pp}$.

OCHOA, H., 1978. Algunas consideraciones para la evaluación del Plan de Estudios de la Escuela de Ingeniería Agronōmi ca de la Universidad del Zulia. VI Conferencia Latinoame ricana de Educación Agrícola Superior. ALEAS. Acta Fi nal Tomo II. Maracaibo.

PINTO, J. B., 1972, Extensiōn Agrícola y Educaciōn: una disyuntiva crîtica. U.C.V. Facultad de Agronomia. Mimeo. Maracay. $63 \mathrm{pp}$.

RAUCIERE, J., 1971. Sobre a teoria da ideologia, a politica de Althusser. Portucalense Editora. Porto, $42 \mathrm{pp}$.

SANTOS, T. dos, 1977. Dependencia y Cambio Social. U.C.V. Divisiōn de Publicaciones. Caracas, $153 \mathrm{pp}$. 
SILVA M. H. e SONNTAG, H. R., .1976. Universidad, dependencia y revolución. Siglo XXI Editores. México, $217 \mathrm{pp}$.

STAVENHAgEN, R., 1974. Sete teses equivocadas sobre América Latina. In: Sociologia do Desenvolvimento. Tomo I. Zahar Editores. Rio de Janeiro, $130 \mathrm{pp}$.

S.V.I.A. (Sociedad Venezolana de Ingenieros Agrōnomos), 1975 La Educación Agrícola Superior en Venezuela. Maracaibo, $16 \mathrm{pp}$.

VILLASMIL, J. J., 1977. Analisis de los procesos de formaciōn de personal técnico y científico para el desarrollo agrícola. Seminario LUZ-CONICIT-CENDES. Mimeo. Maracaibo, $23 \mathrm{pp}$.

V PLAN, 1976. Sector Agrīcola. Capītulo III, Paz Pérez, C. A., Caracas. $311 \mathrm{pp}$.

YOPO, B., 1971. La Transformación necesaria del Ingeniero Agrōnomo. Mimeo. I.I.C.A., Guatemala, 16 pp.

YOPO, B., 1978. La unidimensionalidad del profesional en Ciencias Agropecuarias. In:Revista de la VI Conferencia Latinoamericana de Educación Agricola Superior. ALEAS. Maracaibo, $30 \mathrm{pp}$. 
128.

APE $\bar{E} N I C E$ 
TABElA I - Setor Agrícola. Produção. Toneladas métricas. Venezuela, 1972/1976.

\begin{tabular}{lrrrrrr}
\hline $\begin{array}{l}\text { Produtos Caracteristicos } \\
\text { Agrícola Vegetal }\end{array}$ & 1972 & 1973 & 1974 & 1975 & 1976 \\
\hline Cereais: & & & & & & \\
Arroz (em casca) & 164.691 & 301.899 & 296.552 & 362.925 & 276.770 \\
Milho & 506.316 & 454.423 & 553.761 & 653.412 & 532.147 \\
Sorgo & 7.128 & 8.682 & 34.050 & 70.380 & 237.886 \\
Trigo & 639 & 682 & 627 & 532 & 560
\end{tabular}

Grãos Leguminosos:

$\begin{array}{lrrrrr}\text { Ervilha } & 1.621 & 1.054 & 1.212 & 1.326 & 1.450 \\ \text { Feijão } & 21.397 & 14.728 & 23.646 & 25.098 & 20.098 \\ \text { "Frijol" (+) } & 8.171 & 10.411 & 9.248 & 12.031 & 9.995 \\ \text { "Quinchoncho* (+) } & 4.875 & 3.949 & 3.649 & 3.422 & 3.875\end{array}$

Raízes e Tubérculos:

Mandioquinha
Batata doce
"Mapuey"
Carā
Inhame
Mandioca
Batata

Texteis e Oleaginosos:

Gergelim
Algodão
Copra
Amendoim (em casca)
Sisal (fibra)

\section{Frutas:}

Abacate
Banana (1)
Côco (nozes) em mi-
les de unidades
Graviola
Goiaba
Mamão
Mañá

$\begin{array}{rcrrr}19.072 & 1.5298 & 15.922 & 11.585 & 15.473 \\ 30.125 & 30.350 & 31.906 & 26.851 & 28.378 \\ 17.768 & 18.094 & 17.848 & 18.497 & 19.100 \\ 39.521 & 28.684 & 29.402 & 29.928 & 31.884 \\ 52.676 & 41.227 & 42.840 & 44.598 & 47.948 \\ 318.170 & 27.050 & 292.987 & 317.393 & 352.530 \\ 109.397 & 123.638 & 152.331 & 151.647 & 135.030\end{array}$

$\begin{array}{rrrrr}59.245 & 78.438 & 71.824 & 65.036 & 61.760 \\ 57.271 & 60.038 & 69.598 & 87.509 & 65.634 \\ 17.230 & 18.840 & 18.320 & 17.809 & 18.000 \\ 14.361 & 8.777 & 27.871 & 22.489 & 25.180 \\ 13.307 & 14.900 & 13.510 & 13.765 & 14.300\end{array}$

\begin{tabular}{rrrrr}
56.477 & 56.634 & 55.967 & 57.670 & 59.416 \\
996.975 & 902.235 & 937.185 & 859.935 & 899.790 \\
154.985 & 160.080 & 158.340 & 153.922 & 154.880 \\
2.663 & 2.928 & 3.171 & 3.369 & 3.580 \\
4.732 & 4.897 & 5.017 & 5.090 & 5.120 \\
51.602 & 55.214 & 49.023 & 59.731 & 63.060 \\
78.896 & 79.290 & 83.836 & 86.974 & 89.235 \\
& & \multicolumn{3}{c}{ continua ... }
\end{tabular}


TABELA I - Continuação

\begin{tabular}{lrrrrrr}
\hline $\begin{array}{l}\text { Produtos Característicos } \\
\text { Agricola Vegetal }\end{array}$ & 1972 & 1973 & 1974 & 1975 & 1976 \\
\hline & & & & & & \\
\hline
\end{tabular}

HHortaliças :

$\begin{array}{lrrrrr}\text { Alho } & 2.054 & 1.902 & 3.779 & 3.579 & 3.240 \\ \text { Beringela } & 1.928 & 2.176 & 2.381 & 2.605 & 2.880 \\ \text { Cebola } & 48.484 & 35.433 & 32.730 & 42.148 & 50.340 \\ \text { Couve-flor } & 1.855 & 2.147 & 2.332 & 2.402 & 2.618 \\ \text { Alface } & 5.043 & 5.092 & 5.367 & 4.873 & 4.990 \\ \text { Pepino } & 6.582 & 7.188 & 7.594 & 7.916 & 8.350 \\ \text { Pimentão } & 6.081 & 6.584 & 8.763 & 8.036 & 11.840 \\ \text { Beterraba } & 4.475 & 4.778 & 4.927 & 4.795 & 4.960 \\ \text { Repolho } & 12.974 & 13.613 & 13.900 & 14.237 & 14.620 \\ \text { Tomate } & 79.895 & 84.134 & 93.757 & 100.840 & 133.190 \\ \text { Vagem } & 3.193 & 3.453 & 3.746 & 3.885 & 4.110 \\ \text { Cenoura } & 11.721 & 14.972 & 14.656 & 15.357 & 16.554 \\ \text { Outras hortaliças } & 8.996 & 10.234 & 10.899 & 11.958 & 12.630\end{array}$

Café, Cacau e outros:

$\begin{array}{lrrrrr}\text { Cacau } & 16.718 & 19.081 & 17.263 & 19.336 & 16.650 \\ \text { Café } & 40.406 & 65.926 & 45.878 & 64.611 & 49.580 \\ \text { Cana de açücar (2) } & 5.736 .436 & 5.240 .675 & 5.895 .291 & 5.482 .187 & 5.768 .500 \\ \text { "Plätano" (3) } & 282.440 & 280.135 & 382.311 & 369.729 & 373.086 \\ \text { Tabaco } & 12.537 & 13.433 & 14.347 & 15.771 & 16.160\end{array}$

(+) Variedades de feijão pequenos

(1): Dado original em cachos com peso aproximado em kgs. $15.00 \mathrm{c} / \mathrm{u}$.

(2): Inclui o destinado na elaboração de açūcar e rapadura.

(3): Dado original em unidades e com peso médio aproximado de kgs. $0.265 \mathrm{c} / \mathrm{u}$.

Fontes: M.A.C. - D.G.E. e B.C.V. 
TABELA II - Setor Agricola. Area colhida em hectares. Venezuela, 1972-1976

\begin{tabular}{|c|c|c|c|c|c|}
\hline Agrícola Vegetal & 1972 & 1973 & 1974 & 1975 & 1976 \\
\hline Cereais: & 536.879 & 559.556 & 609.661 & 665.145 & 696.589 \\
\hline $\begin{array}{l}\text { Arroz } \\
\text { Mijho } \\
\text { Sorgo } \\
\text { Trigo }\end{array}$ & $\begin{array}{r}65.336 \\
465.062 \\
5.039 \\
1.442\end{array}$ & $\begin{array}{r}113.034 \\
438.918 \\
6.121 \\
1.483\end{array}$ & $\begin{array}{r}117.309 \\
462.383 \\
28.394 \\
1.575\end{array}$ & $\begin{array}{r}173.548 \\
506.151 \\
43.996 \\
1.450\end{array}$ & $\begin{array}{r}92.875 \\
488.674 \\
113.658 \\
1.382\end{array}$ \\
\hline Grãos Leguminosos: & 96.973 & 78.161 & 92.049 & 100.573 & 100.709 \\
\hline $\begin{array}{l}\text { Ervilha } \\
\text { Feijão } \\
\text { "Frijol" (+) } \\
\text { "Quinchoncho" (+) }\end{array}$ & $\begin{array}{r}3.945 \\
64.427 \\
18.805 \\
9.796\end{array}$ & $\begin{array}{r}2.773 \\
42.892 \\
23.720 \\
8.776\end{array}$ & $\begin{array}{r}3.641 \\
63.084 \\
17.609 \\
7.715\end{array}$ & $\begin{array}{c}3790 \\
63.738 \\
25.541 \\
7.504\end{array}$ & $\begin{array}{r}3.920 \\
65.042 \\
24.084 \\
7.663\end{array}$ \\
\hline Raizes e Tubērculos: & 80.155 & 66.474 & 76.917 & 71.370 & 75.514 \\
\hline $\begin{array}{l}\text { Mandi oquinha } \\
\text { Batata doce } \\
\text { "Mapuey" } \\
\text { Carā } \\
\text { Inhame } \\
\text { Mandioca } \\
\text { Batata }\end{array}$ & $\begin{array}{c}4.146 \\
2.439 \\
2.301 \\
8.694 \\
9.071 \\
40.609 \\
12.895\end{array}$ & $\begin{array}{r}3.039 \\
2.450 \\
2.320 \\
5.989 \\
6.445 \\
33.854 \\
12.377\end{array}$ & $\begin{array}{r}3.359 \\
2.603 \\
2.289 \\
7.776 \\
7.016 \\
39.564 \\
14.310\end{array}$ & $\begin{array}{r}2.463 \\
2.172 \\
2.231 \\
5.206 \\
7.676 \\
37.417 \\
14.105\end{array}$ & $\begin{array}{r}3.113 \\
2.286 \\
2.436 \\
5.947 \\
7.980 \\
40.225 \\
13.527\end{array}$ \\
\hline Texteis e Oleaginosas: & 192.253 & 232.053 & 280.085 & 247.776 & 231.786 \\
\hline $\begin{array}{l}\text { Gergelim } \\
\text { Algodäo } \\
\text { Amendoim } \\
\text { Sisal }\end{array}$ & $\begin{array}{r}107.706 \\
56.320 \\
17.762 \\
10.465\end{array}$ & $\begin{array}{r}151.037 \\
58.803 \\
10.663 \\
11.550\end{array}$ & $\begin{array}{r}174.036 \\
64.668 \\
30.701 \\
10.680\end{array}$ & $\begin{array}{r}136.472 \\
78.362 \\
22.104 \\
10.838\end{array}$ & $\begin{array}{r}134.260 \\
61.169 \\
24.235 \\
12.122\end{array}$ \\
\hline Frutas: & 144.963 & 141.562 & 142.298 & 141.272 & 143.889 \\
\hline $\begin{array}{l}\text { Abacate } \\
\text { Banana } \\
\text { Cóco } \\
\text { Graviola } \\
\text { Goi aba } \\
\text { Mamão } \\
\text { Manga } \\
\text { Laranja } \\
\text { Melancia }\end{array}$ & $\begin{array}{r}12.408 \\
51.003 \\
19.651 \\
1.003 \\
1.664 \\
3.053 \\
6.021 \\
31.146 \\
6.347\end{array}$ & $\begin{array}{r}12.415 \\
45.782 \\
20.123 \\
1.016 \\
1.716 \\
3.112 \\
6.030 \\
32.170 \\
6.392\end{array}$ & $\begin{array}{r}12.420 \\
46.648 \\
19.660 \\
1.021 \\
1.757 \\
3.205 \\
6.078 \\
32.212 \\
6.418\end{array}$ & $\begin{array}{r}12.467 \\
44.920 \\
18.677 \\
1.075 \\
1.769 \\
3.285 \\
6.102 \\
33.371 \\
6.461\end{array}$ & $\begin{array}{r}12.497 \\
45.371 \\
19.109 \\
1.140 \\
1.780 \\
3.370 \\
6.197 \\
33.469 \\
6.315\end{array}$ \\
\hline
\end{tabular}


TABELA 2 - Continuação

\begin{tabular}{|c|c|c|c|c|c|}
\hline Agrícola Vegetal & 1972 & 1973 & 1974 & 1975 & 1976 \\
\hline Abacaxi & 2.681 & 2.533 & 2.444 & 2.279 & 2.463 \\
\hline Outras frutas & 9.986 & 10.273 & 10.435 & 10.876 & 12.178 \\
\hline Hortaliças: & 15.851 & 15.595 & 16.188 & 17.970 & 20.106 \\
\hline Alho & 560 & 541 & 856 & 753 & 692 \\
\hline Beringela & 156 & 171 & 189 & 197 & 226 \\
\hline Cebola & 2.306 & 1.755 & 1.862 & 2.376 & 2.697 \\
\hline Couve-flor & 158 & 162 & 165 & 174 & 189 \\
\hline Alface & 241 & 232 & 245 & 229 & 262 \\
\hline Pepino & 691 & 705 & 724 & 745 & 731 \\
\hline Pimentão & 694 & 663 & 802 & 761 & 922 \\
\hline Beterraba & 344 & 359 & 367 & 392 & 461 \\
\hline Repolho & 510 & 512 & 520 & 529 & 582 \\
\hline Toma te & 5.038 & 5.120 & 4.923 & 5.923 & 6.986 \\
\hline Vagem & 613 & 662 & 695 & 723 & 771 \\
\hline Cenoura & 945 & 993 & 1.025 & 1.043 & 1.257 \\
\hline Outras hortaliças & 3.595 & 3.720 & 3.815 & 4.125 & 4.330 \\
\hline Café, Cacau e Outros: & 486.291 & 479.306 & 490.894 & 493.768 & 488.669 \\
\hline Cacau & 67.408 & 70.346 & 69.990 & 71.446 & 71.767 \\
\hline Café & 276.719 & 272.461 & 272.497 & 275.438 & 268.438 \\
\hline Cana-de-açūcar & 73.610 & 69.601 & 78.782 & 78.278 & 79.622 \\
\hline "Plātano" & .59 .641 & 57.810 & 59.869 & 57.542 & 57.982 \\
\hline Tabaco & 8.913 & 9.088 & 9.756 & 11.064 & 10.860 \\
\hline TOTAL & \multicolumn{5}{|c|}{ 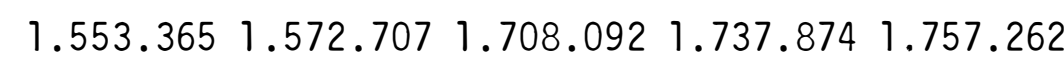 } \\
\hline
\end{tabular}

(+) Variedades de feijão pequenos

Fonte: M.A.C. e B.C.V. 
TABELA III - Setor Agrỉcola. Produção bruta. Milhões de bolivares a preços pagos ao produtor). Vene zuela, $1972 / 1976$

\begin{tabular}{|c|c|c|c|c|c|}
\hline Agrícola Vegetal & 1972 & 1973 & 1974 & 1975 & 1976 \\
\hline Produtos característicos & 4.393 & 4.627 & 4.974 & 5.264 & 5.105 \\
\hline Agrícola Vegetal & 1.811 & 1.940 & 2.066 & 2.241 & 2.150 \\
\hline Cereais: & 299 & 361 & 405 & 49 & 447 \\
\hline $\begin{array}{l}\text { Arroz } \\
\text { Milho } \\
\text { Sorgo } \\
\text { Trigo }\end{array}$ & $\begin{array}{r}99 \\
198 \\
2 \\
0\end{array}$ & $\begin{array}{r}181 \\
177 \\
3 \\
0\end{array}$ & $\begin{array}{r}178 \\
216 \\
11 \\
0\end{array}$ & $\begin{array}{r}217 \\
255 \\
22 \\
0\end{array}$ & $\begin{array}{r}167 \\
207 \\
74 \\
0\end{array}$ \\
\hline Grãos Leguminosos: & 40 & 34 & 43 & 49 & 40 \\
\hline $\begin{array}{l}\text { Ervilha } \\
\text { Feijão } \\
\text { "Frijol" (t) } \\
\text { "Quinchoncho" (t) }\end{array}$ & $\begin{array}{r}1 \\
25 \\
10 \\
4\end{array}$ & $\begin{array}{r}1 \\
17 \\
13 \\
3\end{array}$ & $\begin{array}{r}1 \\
28 \\
11 \\
3\end{array}$ & $\begin{array}{r}1 \\
30 \\
15 \\
3\end{array}$ & $\begin{array}{r}1 \\
24 \\
12 \\
3\end{array}$ \\
\hline Raĩzes e Tubērculos: & 219 & 201 & 221 & 224 & 231 \\
\hline $\begin{array}{l}\text { Mandioquinha } \\
\text { "Batata doce } \\
\text { "Mapuey" } \\
\text { Carā } \\
\text { Inhame } \\
\text { Mandioca } \\
\text { Batata }\end{array}$ & $\begin{array}{l}13 \\
10 \\
17 \\
22 \\
34 \\
73 \\
56\end{array}$ & $\begin{array}{l}11 \\
10 \\
11 \\
16 \\
27 \\
63 \\
63\end{array}$ & $\begin{array}{l}11 \\
11 \\
11 \\
16 \\
28 \\
67 \\
77\end{array}$ & $\begin{array}{r}8 \\
9 \\
11 \\
17 \\
29 \\
73 \\
77\end{array}$ & $\begin{array}{r}11 \\
9 \\
12 \\
18 \\
31 \\
81 \\
69\end{array}$ \\
\hline Texteis e Oleaginosos: & 208 & 226 & 263 & 269 & 242 \\
\hline $\begin{array}{l}\text { Gerge } 1 \text { im } \\
\text { Algodão } \\
\text { Copra } \\
\text { Amendo im } \\
\text { Sisal }\end{array}$ & $\begin{array}{l}71 \\
78 \\
22 \\
25 \\
12\end{array}$ & $\begin{array}{l}93 \\
82 \\
23 \\
15 \\
13\end{array}$ & $\begin{array}{l}85 \\
95 \\
22 \\
49 \\
12\end{array}$ & $\begin{array}{r}77 \\
120 \\
21 \\
39 \\
12\end{array}$ & $\begin{array}{l}73 \\
90 \\
22 \\
44 \\
13\end{array}$ \\
\hline Frutas: & 351 & 348 & 363 & 357 & 372 \\
\hline $\begin{array}{l}\text { Abacate } \\
\text { Cóco } \\
\text { Graviola }\end{array}$ & $\begin{array}{r}24 \\
150 \\
19\end{array}$ & $\begin{array}{r}24 \\
135 \\
20\end{array}$ & $\begin{array}{r}24 \\
747 \\
20\end{array}$ & $\begin{array}{l}25 \\
129 \\
19 \\
\text { continua }\end{array}$ & $\begin{array}{r}26 \\
135 \\
19 \\
\ldots\end{array}$ \\
\hline
\end{tabular}


TABELA III - Continuação

\begin{tabular}{|c|c|c|c|c|c|}
\hline Agrīcola Vegetal & 1972 & 1973 & 1974 & 1975 & 1976 \\
\hline Goiaba & 3 & 3 & 3 & 3 & 3 \\
\hline Mamão & 15 & 17 & 18 & 18 & 19 \\
\hline Manga & 9 & 10 & 10 & 10 & 11 \\
\hline Laranja & 60 & 64 & 68 & 72 & 78 \\
\hline Melancia & 15 & 16 & 18 & 18 & 17 \\
\hline Abacaxi & 11 & 11 & 9 & 8 & 7 \\
\hline Outras frutas & 42 & 45 & 49 & 52 & 53 \\
\hline Hortaliças: & 113 & 108 & 121 & 132 & 147 \\
\hline Alho & 8 & 7 & 15 & 14 & 13 \\
\hline Beringela & 1 & 1 & 1 & 1 & 1 \\
\hline Cebola & 34 & 25 & 23 & 30 & 35 \\
\hline Couve-flor & 1 & 1 & 1 & 1 & 2 \\
\hline Alface & 4 & 4 & 4 & 4 & 4 \\
\hline Pepino & 3 & 3 & 3 & 4 & 4 \\
\hline Pimentão & 4 & 4 & 6 & 5 & 8 \\
\hline Beterraba & 3 & 3 & 3 & 3 & 3 \\
\hline Repolho & 7 & 7 & 7 & 8 & 8 \\
\hline Tomate & 34 & 36 & 40 & 43 & 49 \\
\hline Vagem & 3 & 3 & 4 & 4 & 4 \\
\hline Cenoura & 6 & 8 & 8 & 8 & 9 \\
\hline Outras hortaliças & 5 & 6 & 6 & 7 & 7 \\
\hline Café, Cacau e Outros: & 581 & 662 & 650 & 716 & 671 \\
\hline Cacau & 46 & 52 & 47 & 53 & 46 \\
\hline Café & 140 & 228 & 159 & 224 & 172 \\
\hline Cana-de-açūcar & 212 & 194 & 212 & 203 & 213 \\
\hline "Plātano" & 106 & 106 & 144 & 739 & 141 \\
\hline Tabaco & 77 & 82 & 88 & 97 & 99 \\
\hline
\end{tabular}

(+) Variedades de feijão pequenos

Fonte: M.A.C. . M.O.P. - D.G.E. - I.A.N. - C.B.R. e B.C.V. 
TABELA IV - Disciplinas Bio-físicas e Sócio-econōmicas oferecidas pela Faculdade de Agronomia da Univers $\underline{i}$ dade de Zulia, Maracaibo, Venezuela. 1978

\begin{tabular}{ll}
\hline Disciplina: Bio-física & $\begin{array}{c}\text { Semestre } \\
\text { Nümeróditos }\end{array}$ \\
\hline
\end{tabular}

Química Analitica Qualitativa

Matemática Aplicada

Botānica I

30

Fisiologia Animal

Fisica Geral

Desenho Geral

Quĩmica orgānica

Botānica II

Estatistica I

Quimica Analitica Quantitativa

Hidrāulica

Agrometeorologia

Bioquimica

Estatistica II

Introdução ao Estudo dos Insetos

Maquinaria Agrícola I

Topografia I

Topografia Geral

Edafologia I

Alimentação Animal

Topografía II

Maquinaria Agricola I I

Fisiologia Vegetal I

Genētica I

Introdução às Doenças das Plantas

Entomologia Económica

Edafologia II

Irrigação e Drenagem I

Genētica II

Fisiologia Vegetal II

Explorações Pecuārias Geral

Fertilizantes e enmendas

Fotointerpretação

Investigação (PV)

Nutrição Animal

Fitopatologia Económica

Ecologia Vegetal

Controle das Ervas-Daninhas

Conservação de Solos

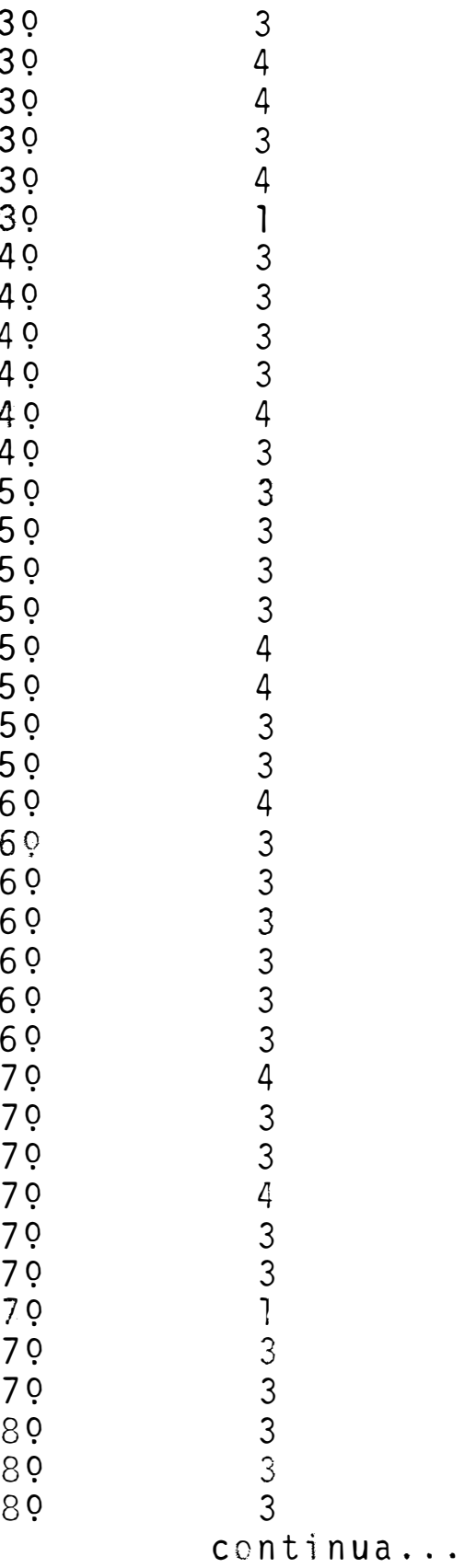


TABELA IV - Continuação

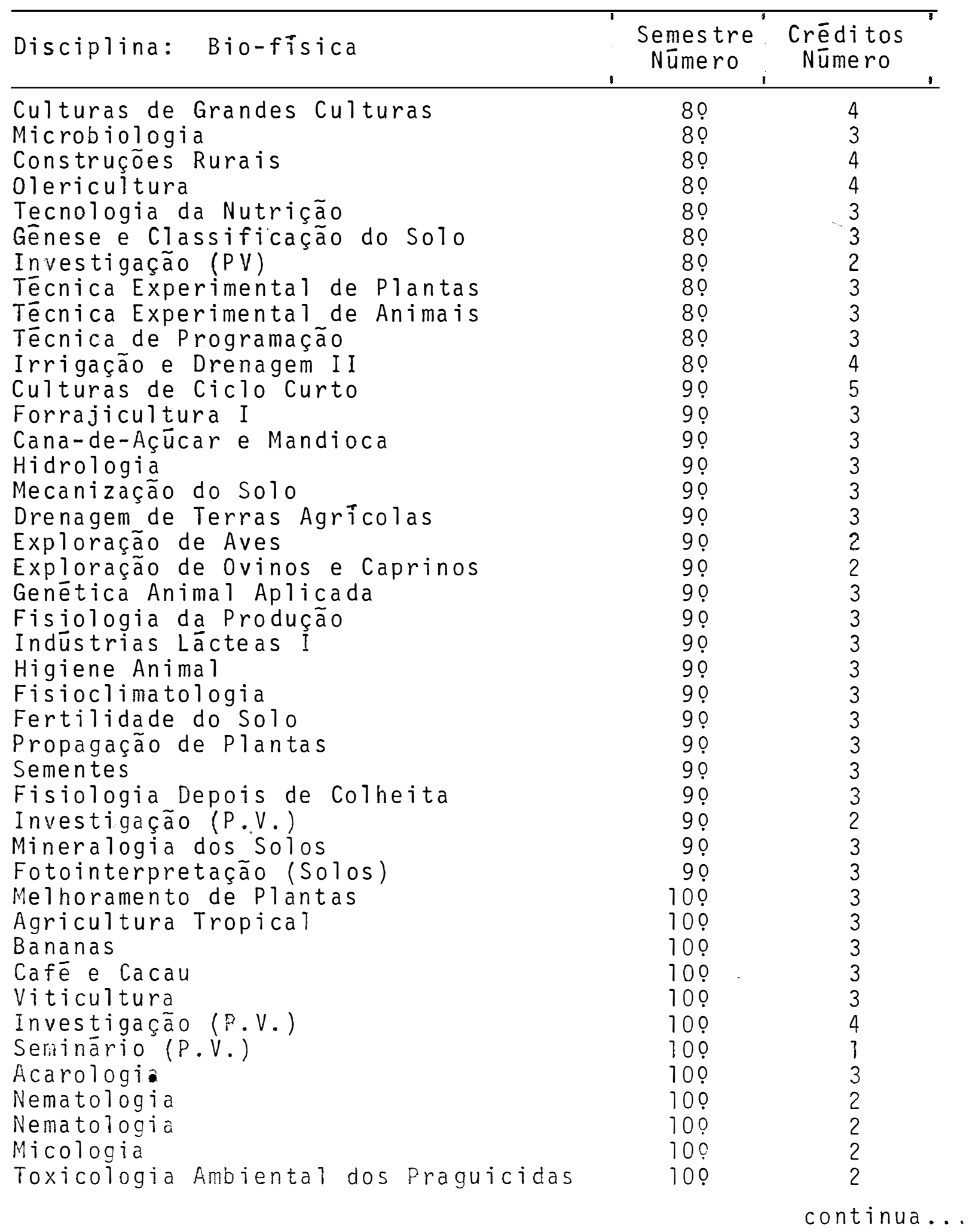


TABELA IV - Continuação

\begin{tabular}{|c|c|c|}
\hline Disciplina: Bio-física & $\begin{array}{c}\text { Semestre } \\
\text { Nūmero }\end{array}$ & $\begin{array}{c}\text { Crēditos } \\
\text { Nümero }\end{array}$ \\
\hline $\begin{array}{l}\text { Sanidade Vegetal } \\
\text { Ecologia dos Insetos } \\
\text { Agrologia } \\
\text { Desenho de Pequenos Sistemas de Irrigação } \\
\text { Planejamento Fisico de Fazendas } \\
\text { Topografia Aplicada } \\
\text { Operação e Manutenção de Pequenos Sis } \\
\text { temas de Irrigação } \\
\text { Desenhos de Pequenas Barragens } \\
\text { Levantamentos Agrológicos } \\
\text { Manejo de Solos } \\
\text { Fisica de Solos } \\
\text { Quimica de Solos } \\
\text { Geologia e Geomofologia } \\
\text { Solos da Venezuela } \\
\text { Maquinaria Agricola III } \\
\text { Exploração de Porcos } \\
\text { Forrajicultura II } \\
\text { Gado de Leite } \\
\text { Gado de Carne } \\
\text { Indūstrias Lăcteas II } \\
\text { Planejamento e Desenvolvimento de Fazendas } \\
\text { Indústria de Carne } \\
\text { Higiene Animal }\end{array}$ & $\begin{array}{l}100 \\
100 \\
100 \\
100 \\
100 \\
100 \\
100 \\
100 \\
100 \\
100 \\
100 \\
100 \\
100 \\
100 \\
100 \\
100 \\
100 \\
100 \\
100 \\
100 \\
100 \\
100 \\
100\end{array}$ & $\begin{array}{l}3 \\
3 \\
3 \\
3 \\
3 \\
3 \\
3 \\
3 \\
4 \\
3 \\
3 \\
3 \\
3 \\
3 \\
3 \\
3 \\
3 \\
4 \\
4 \\
4 \\
4 \\
3 \\
3 \\
3\end{array}$ \\
\hline $104(86 \%)$ & & 317 \\
\hline
\end{tabular}


TABELA IV - Continuação

\begin{tabular}{|c|c|c|}
\hline Disciplina: Sōcio-econōmicas & $\begin{array}{c}\text { Semestre } \\
\text { Nümero }\end{array}$ & $\begin{array}{l}\text { Créditos } \\
\text { Nümero }\end{array}$ \\
\hline Economia Agrícola I & 60 & 3 \\
\hline Legislação e Direito Agrārio & 70 & 3 \\
\hline Extensão Agrĩcola I & 70 & 3 \\
\hline Economia Agrícola II & 80 & 3 \\
\hline Administração Rural & 80 & 3 \\
\hline Crédito Agrícola & 90 & 3 \\
\hline Sociologia Rural I & 90 & 3 \\
\hline Formulação e Avaliação de Projetos & 90 & 3 \\
\hline Comercialização de Produtos Agropecuārios & 100 & 3 \\
\hline Organizações Agrārias & 109 & 3 \\
\hline Desenvolvimento Económico & 109 & 3 \\
\hline Extensão Agrĩcola II & 100 & 3 \\
\hline Sociologia Rural II & 100 & 3 \\
\hline Reforma Agrāria & 109 & 3 \\
\hline Redação Técnica & 100 & 3 \\
\hline $15(14 \%)$ & & 44 \\
\hline
\end{tabular}

Fonte: Plano de Estudos para Egressados de Estudos Gerais. Faculdade de Agronomia de L.U.Z. Maracaibo. 
TABELA V - Objetivos propostos para as disciplinas oferecidas pela Faculdade de Agronomia da Universidade de Zu1ia, Maracaibo, Venezuela, 1970/1976

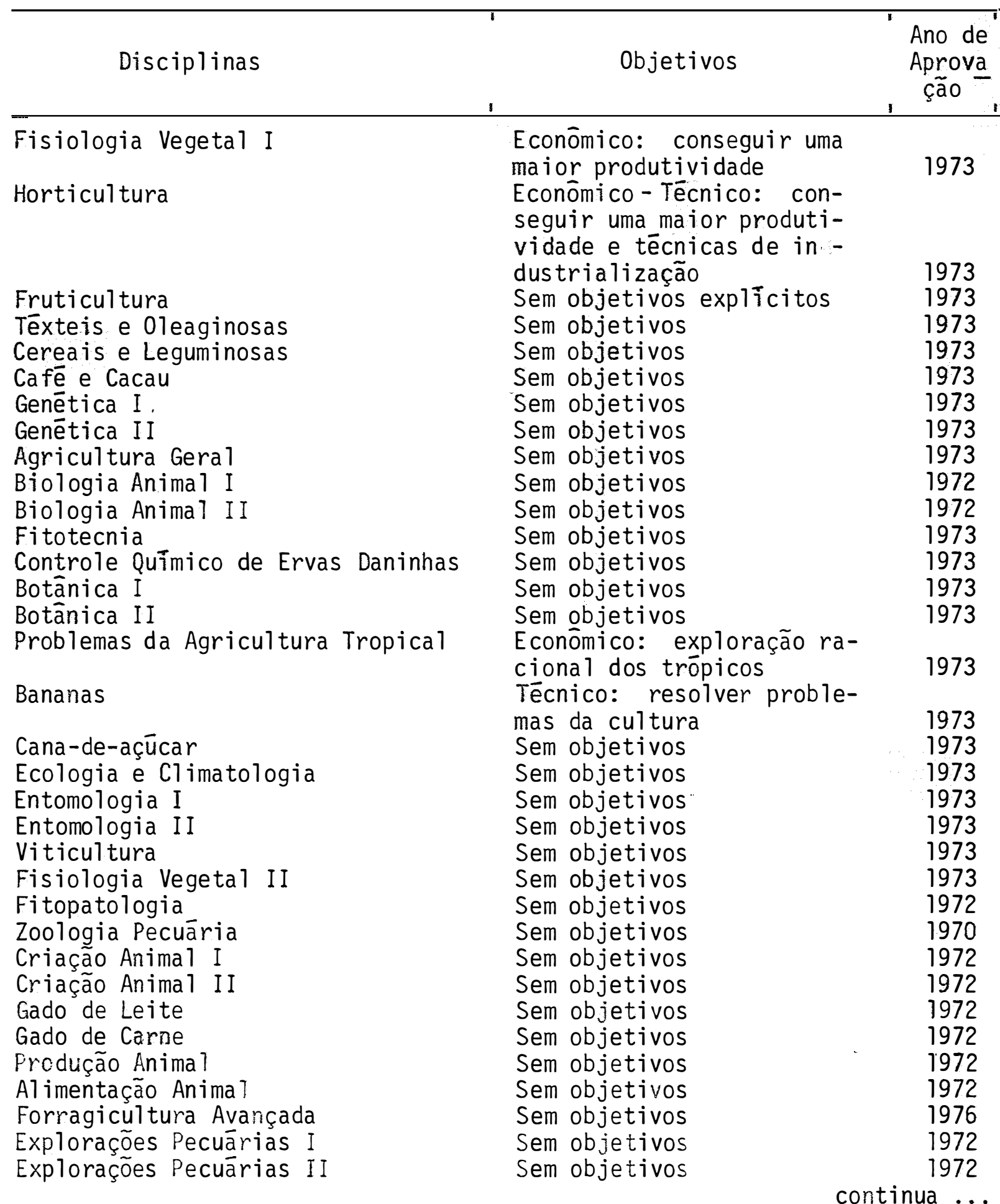


TABELA V - Continuação

\begin{tabular}{|c|c|c|}
\hline Disciplinas & Objetivos & $\begin{array}{l}\text { Ano de } \\
\text { Aprova } \\
\text { ção }\end{array}$ \\
\hline $\begin{array}{l}\text { Higiene Animāl } \\
\text { Indūstrias Lä́cteas }\end{array}$ & $\begin{array}{l}\text { Sem objetivos } \\
\text { Econömico-Técnico: indus- } \\
\text { trializacão do leite }\end{array}$ & $\begin{array}{l}1972 \\
1972\end{array}$ \\
\hline $\begin{array}{l}\text { Nutrição Animal } \\
\text { Pastagens } \\
\text { Planejamento Físico de Fazendas } \\
\text { Matemātica I } \\
\text { Matemătica II } \\
\text { Matemattica II } \\
\text { Topografia I } \\
\text { Topografia II } \\
\text { Irrigação e Drenagem I }\end{array}$ & $\begin{array}{l}\text { Sem objetivos } \\
\text { Sem objetivos } \\
\text { Sem objetivos } \\
\text { Sem objetivos } \\
\text { Sem objetivos } \\
\text { Sem objetivos } \\
\text { Sem objetivos } \\
\text { Sem objetivos } \\
\text { Técnico: uso racional da }\end{array}$ & $\begin{array}{l}1972 \\
1972 \\
1974 \\
1973 \\
1973 \\
1973 \\
1973 \\
1973\end{array}$ \\
\hline $\begin{array}{l}\text { Irrigação e Drenagem II } \\
\text { Maquinaria Agrícola I } \\
\text { Maquinaria Agriccola II }\end{array}$ & $\begin{array}{l}\text { àgua } \\
\text { Sem objetivos } \\
\text { Sem objetivos } \\
\text { Sem objetivos }\end{array}$ & $\begin{array}{l}1973 \\
1973 \\
1973 \\
1973\end{array}$ \\
\hline $\begin{array}{l}\text { Desenho de Pequenos Sistemas } \\
\text { de Irrigação }\end{array}$ & Sem objetivos & 1974 \\
\hline $\begin{array}{l}\text { Desenho Geral } \\
\text { Fisica I } \\
\text { Fisica I } \\
\text { Fisica I I } \\
\text { Construções Rurais I } \\
\text { Construçōes Rurais II } \\
\text { Hidräulica Aplicada }\end{array}$ & $\begin{array}{l}\text { Sem objetivos } \\
\text { Sem objetivos } \\
\text { Sem objetivos } \\
\text { Sem objetivos } \\
\text { Sem objetivos } \\
\text { Sem objetivos } \\
\text { Técnico: Retenção artifi- } \\
\text { cial e regularização das } \\
\text { correntes de àguas superfi } \\
\text { ciais }\end{array}$ & $\begin{array}{l}1974 \\
1974 \\
1973 \\
1971 \\
1973 \\
1973\end{array}$ \\
\hline $\begin{array}{l}\text { Hidrologia Agricola } \\
\text { Edafologia I } \\
\text { Edafologia II } \\
\text { Manejo de Solos }\end{array}$ & $\begin{array}{l}\text { Sem objetivos } \\
\text { Sem objetivos } \\
\text { Sem objetivos } \\
\text { Técnico-Economico: melhor } \\
\text { manejo do solo ; incremen - } \\
\text { tar a producão agropecuăria }\end{array}$ & $\begin{array}{l}1973 \\
1975 \\
1975\end{array}$ \\
\hline $\begin{array}{l}\text { Levantamentos Agrológicos } \\
\text { Fertilidade dos Solos } \\
\text { Fotointerpretação } \\
\text { Fisica dos Solos }\end{array}$ & $\begin{array}{l}\text { Sem objetivos } \\
\text { Sem objetivos } \\
\text { Sem objetivos } \\
\text { Técnicos: Formulação e de- } \\
\text { senho de projetos de desen } \\
\text { volvimento de âreas sob in } \\
\text { rigação }\end{array}$ & $\begin{array}{l}1974 \\
1972 \\
1973\end{array}$ \\
\hline
\end{tabular}


TABELA V - Continuação



Fonte: Programas das disciplinas oferecidas na Faculdade de Agronomia de L. U. Z., Maracaibo, Venezuela. 